2. To: (Receiving Organization)

Distribution

5. Proj./Prog./Dept./Div.:

W-058/Startup

8. Originator Remarks:

For release. This test report contains the results of preoperational testing of the water flush system. Attached are: HNF-1552, Rev 0, ECN W-058-376, and ECN W-058-378.

11. Receiver Remarks: 11A. Design Baseline Document? [] Yes [X] No
3. From: (originating organization)

Replacement Cross-Site

Transfer System

6. Design Authority/ Design Agent/Cog. Engr.:

GL Parsons
4. Related EDT No.:

$N / A$

7. Purchase Order No.:

$N / A$

9. Equip./Component No.:

10. System/Bldg./Facility:

SY Farm

12. Major Assm. Dwg. No.:

$\mathrm{H}-2-822409$

13. Permit/Permit Application No.: $\mathrm{N} / \mathrm{A}$

14. Required Response Date:

$\mathrm{N} / \mathrm{A}$

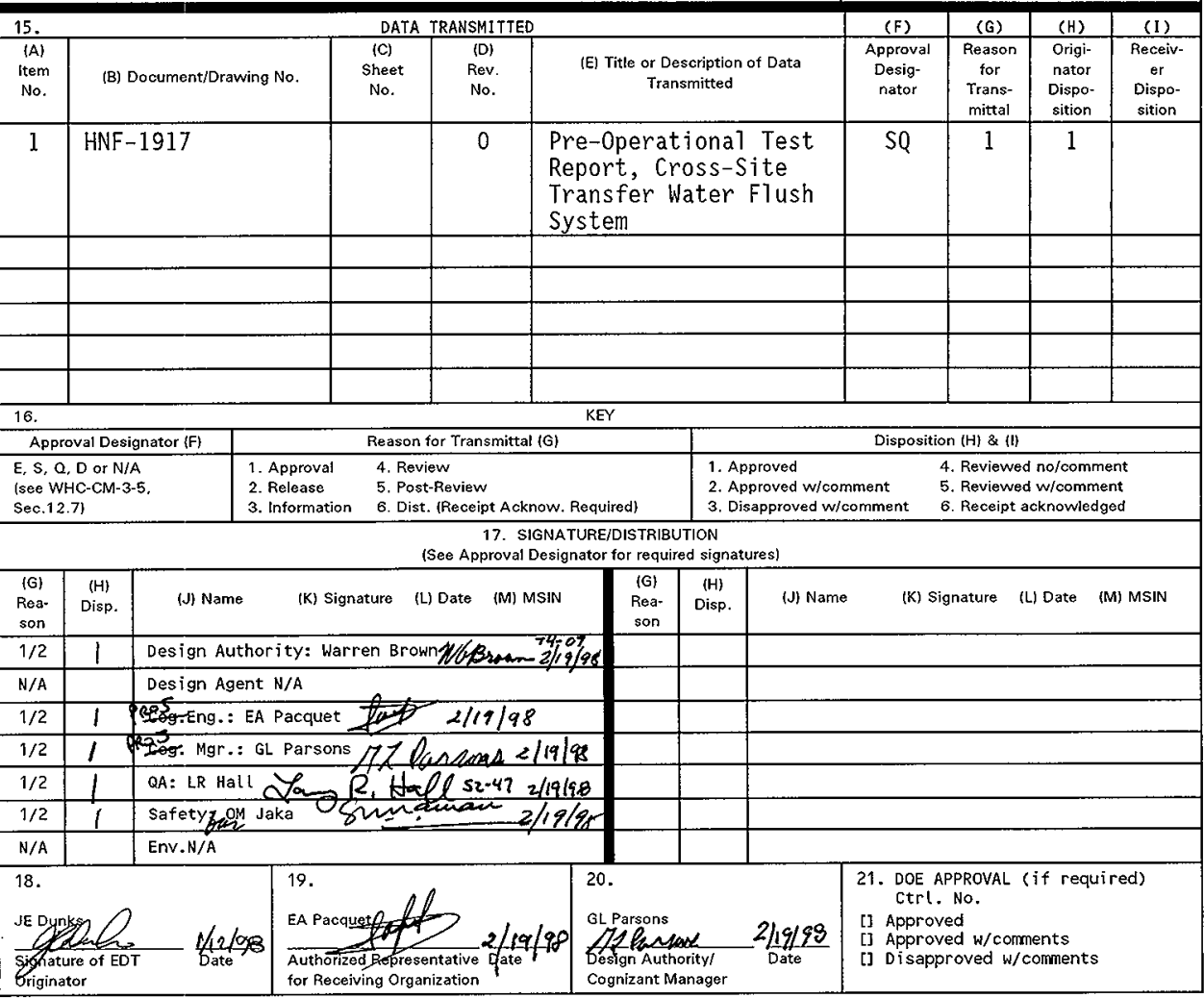


HNF-1917, Rev. 0

\section{PREOPERATIONAL TEST REPORT, CROSS-SITE TRANSFER WATER FLUSH SYSTEM (POTP-001)}

\section{GL Parsons}

Numatec Hanford Corporation, Richland, WA 99352

U.S. Department of Energy Contract DE-AC06-96RL13200

EDT/ECN: 623663

Org Code: $8 \mathrm{C} 160$

UC:

2030

B\&R Code: 39EW31301

Charge Code: N58U7

Tota1 Pages: 8991

tins $\%$ \%o/s.

Key Words: Project $W-058$, Heaters, Caustic Addition, Flush Pump, 302C Tank.

Abstract: This report documents the results of the testing performed per POTP-001, for the Cross-Site Transfer Water Flush System. (HNF1552, Rev. 0) The Flush System consists of a 47,000 gallon tank (302C), a $20 \mathrm{hp}$ pump, two $498 \mathrm{~kW}$ heaters, a caustic addition pump, various valves, instruments, and piping. The purjpose of this system is to provide flush water at $140^{\circ} \mathrm{F}, 140 \mathrm{gpm}$, and $\mathrm{pH} 11-12$ for the Cross-Site Transfer System operation.

TRADEMARK DISCLAIMER. Reference herein to any specific commercial product, process, or service by trade name, trademark, manufacturer, or otherwise, does not necessarily constitute or imply its endorsement, recommendation, or favoring by the United States Government or any agency thereof or its contractors or subcontractors.

Printed in the United States of America. To obtain copies of this document, contact: Document Control Services, P.O. Box 950, Mailstop H6-08, Richland WA 99352, Phone (509) 372-2420;

Fax (509) 376-4989.
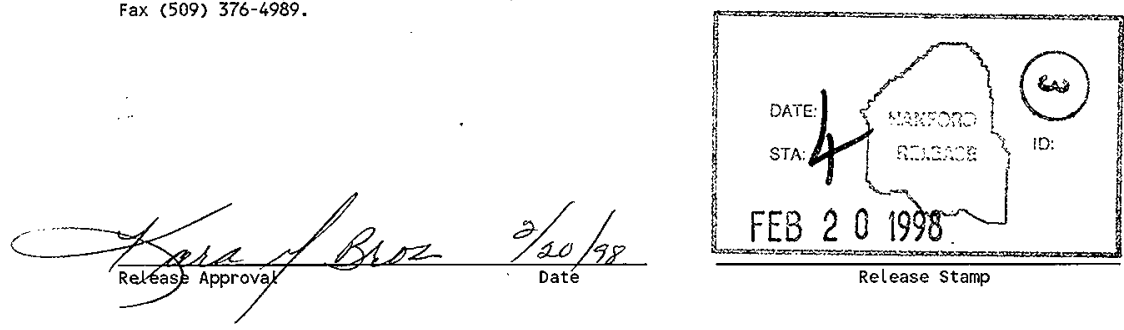

Release Stamp

Approved for Public Release 
HNF-1917 Rev O

APPROVAL DESIGNATOR SO

TEST REPORT APPROVAL BY TEST REVIEW BOARD (TRB)

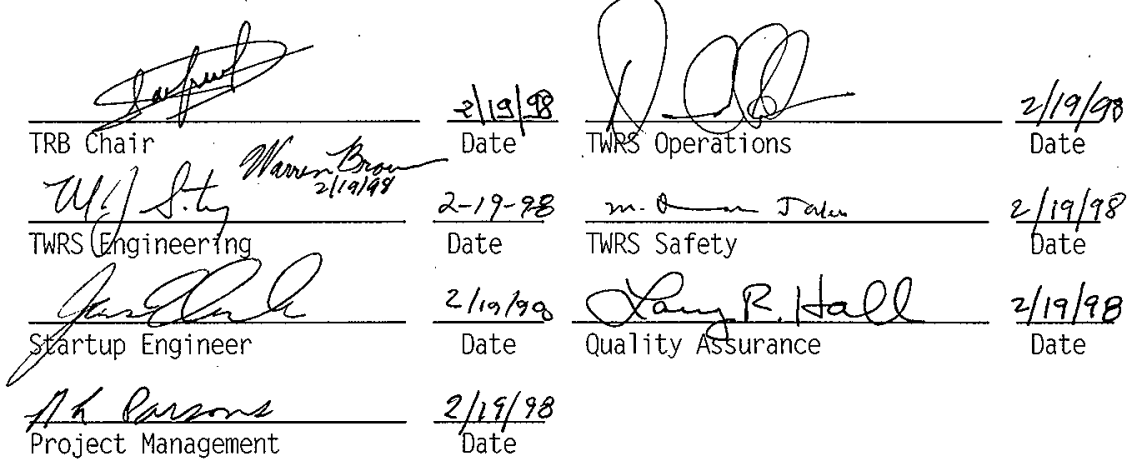

3 
ATTACHMENTS

Attachment-1: Copy of original test procedure with recorded data, and the dispositioned test exception reports.

Attachment-2: ECN W-058-378

Attachment-3: ECN W-058-376

Attachment-4: MCS Caustic to Raw Water Flow Ratio Setting

Attachment-5: Pump P3100A Performance Design Point

Attachment-6: W-058 Interlock Test Listing

Attachment-7: Caustic to Raw Water Flow Measurement Tolerance

\section{REFERENCES}

1. HNF-1552, Rev.0. Preoperationa 7 Testing; Cross-Site Transfer Water Flush System

2. HNF-SD-W058-SUP-002,Rev.1, Project W058 Startup Test P7an

3. Calculation No. W058-P-050, pH Adjustment of Water Using Sodium Hydroxide/Pump Injection rate.

4. ECN $W-058-340$

5. ECN W-058-357

INTRODUCTION

Preoperational test HNF-1552 was performed in November and December 1997 according to the attached testing procedure and attached ECN. Nine test exceptions were generated and dispositioned with the result of the equipment operating properly. Troubleshooting and CGA (Calibration Grooming and Alignment) were required to get the hardware operational for testing. The technical requirements for the cross-site transfer water flush system performance were satisfied.

SUMMARY OF TEST RESULTS

ACCEPTANCE CRITERIA

HNF-1917, Rev. 0 
HNF-1917, Rev. 0

1) Determine the Flush Water Pump performance curve as installed; at 140 gpm the head must be at least $240 \mathrm{ft}$ per vendor information.

(Criteria met)

2) Verify the Flush Water System Sump Pump is operational. (Criteria met)

3) The In-Line Heaters must raise the temperature of water in the test tank to at least $140+/-5 F^{\circ}$.

(Criteria met)

4) The Chemical Addition Pump capacity has been verified to deliver 12.4 $\mathrm{gph} \pm 5 \%$ at a raw water flow of $170 \mathrm{gpm}$. The chemical addition pump shall maintain the corresponding pre-set caustic/water injection ratio. (Criteria met)

5) Local and Remote control devices, instruments and interlocks operate in accordance with design specifications. Specifically: 1) Interlock 18 shuts down pump P-3100 A on low tank level: and 2) Interlock 19 turns off the heater(s) on the Element Sheath High Limit Controller, the Process High Limit Controller, and Flow Switch. Interlock 19 is provided as part of the vendor package.

(Criteria met)

A complete inventory of $W-058$ Interlocks tests is given in Attachment 6

\section{NOTABLE EVENTS}

Minor field hardware adjustments had to be made during the course of testing. These are recorded and described in the Test Log and/or as Test Exceptions.

The caustic addition pump (P-3100B), tested in Sections 2 and 3 , was initially undersized and replaced with a larger model per ECN W-058-357, these test sections were repeated.

The installation design of the P-302C-3 Sump Pump was not complete at the time testing started and the test procedure had to be modified to accommodate the final installation per ECN W-058-376.

Field labeling of circulation heaters HTR-302-1 and HTR-302-2 was initially inversed and corrected per ECN W-058-340.

HNF-1917, Rev. 0 
HNF-1917, Rev. 0

Auxiliary contacts from pump P3100A to PCUI were instal7ed per ECN W-058-376 and required retesting according to test exception 7 .

\section{COMMENTS}

The caustic to raw water flow ratio setting at the MCS is 163\% (see Attachments 4 and 7) to achieve $12.4 \mathrm{gph} \pm 5 \%$ of $25 \% \mathrm{NaOH}$ per $170 \mathrm{gpm}$ of water.

The chemical injection pump P3100B "passed" the POTP-001 requirements; i.e it delivers adequate flow of caustic and automatically maintains the proper ratio between caustic and water as the water flow varies.

\section{CONCLUSION}

The Flush Water System wi1l deliver $140 \mathrm{gpm}$ of $\mathrm{pH} 11$ water at $140^{\circ} \mathrm{F}$ to the cross-site transfer system. 


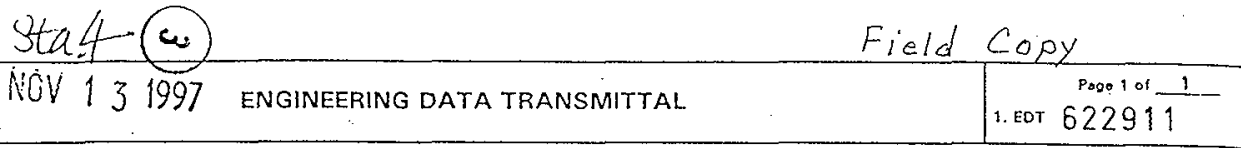

2. To: (Receiving Organization)

Distribution

5. Proj./Prog./Dept./0iv.:

W-058/Startup

8. Originator Remarks:

For Release

11. Receiver Remarks: 11A. Design Baseline Document? [] Yes $[X]$ No
3. From: (Originating organization)

Replacement Cross-Site

Transfer System

6. Design Authority/ Design Agent/Cog. Engr.:

GL Parsons

1. EDT 622911

4. Related EDT NO.:

$$
\therefore \quad N / A
$$

7. Purchase Order Ho.:

$N / A$

9. Equip./Component No.:

P3100A

10. System/Bldg./Facility:

SY Farm

12. Major Assm. Dwg. No.:

H-2-822409

13. Permit/Permit Application No.: $N / A$

14. Required Response Date:

$N / A$

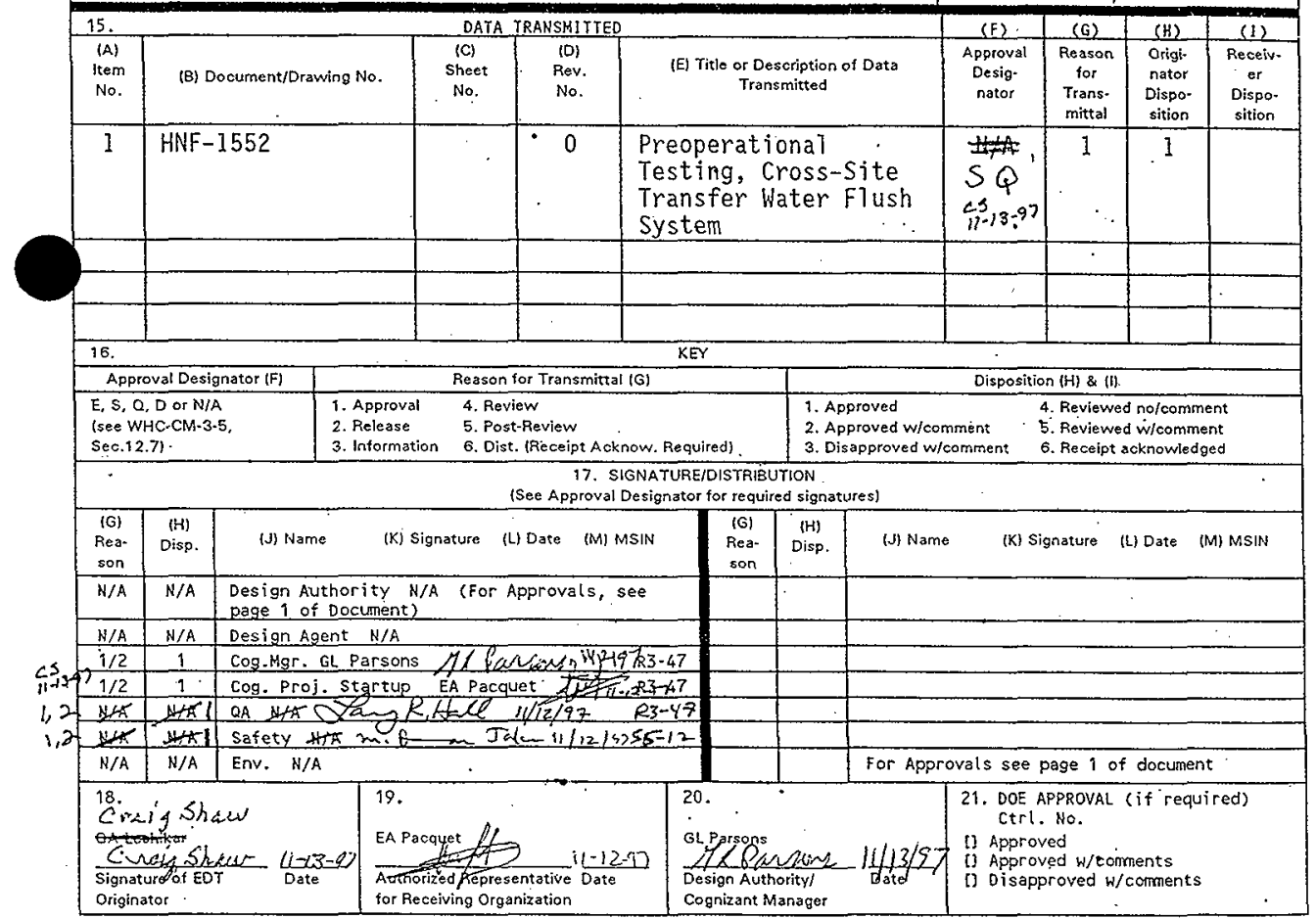

$80-7400-172-2(05 / 96)$ GEF097 


$$
\begin{aligned}
& \text { Flèld Record Copy } \\
& \text { Cunay shew HNF-1552, Rev. } 0
\end{aligned}
$$

\section{Pre-Operational Testing, Cross-Site Transf̣er Water Flush System}

\section{G. L. Parsons}

Numatec Hanford Corporation, Richland, WA 99352

U.S. Department of Energy Contract DE-AC06-96RL13200
EDT/ECN: 622911
Org Code: $8 \mathrm{C6} 610$
B\&R Code: 39EW31301
UC: 2030
Charge Code: N5847
Total Pages: 5152

Key Words: Project W-058, Pre-operational, Flush System, Heater

Abstract: This procedure documents the steps required to fully demonstrate that the flush system caustic addition and heaters meets the pre-operational acceptance criteria given in the Project W-058 Startup Test Plan, HNF-SD-W058-SUP-002

Photocopied materials in this document have been reviewed and verified that the materials are not copyrighted.

IRADEMARK DISCLAIMER. Reference herein to any specific comercial product, process, or service by trade name, trademark, manufacturer, or otherwise, does not necessarily constitute or imply its. endorsement, recommendation, or favoring by the United States Government or any agency thereof or its contractors or subcontractors.

Printed in the United States of America. To obtain copies of this document, contact: Document Control Services, P.O. Box 950, Mailstop H6-08, Richland WA 99352, Phone (509) 372-2420;

Fax (509) 376-4989.
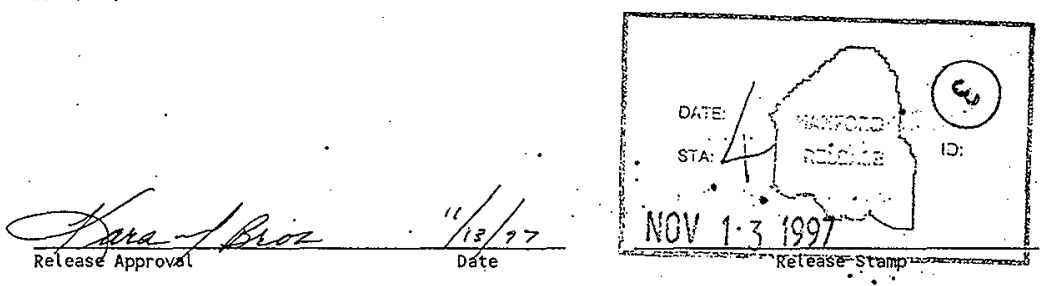

\section{Approved for Public Release}




\section{Author}

Craig P Shaw/Jim Dunks

Print Name/Signature

APPROVAL DESIGNATOR

PROCEDURE APPROVAL BY TEST REVIEW BOARD (TRB)

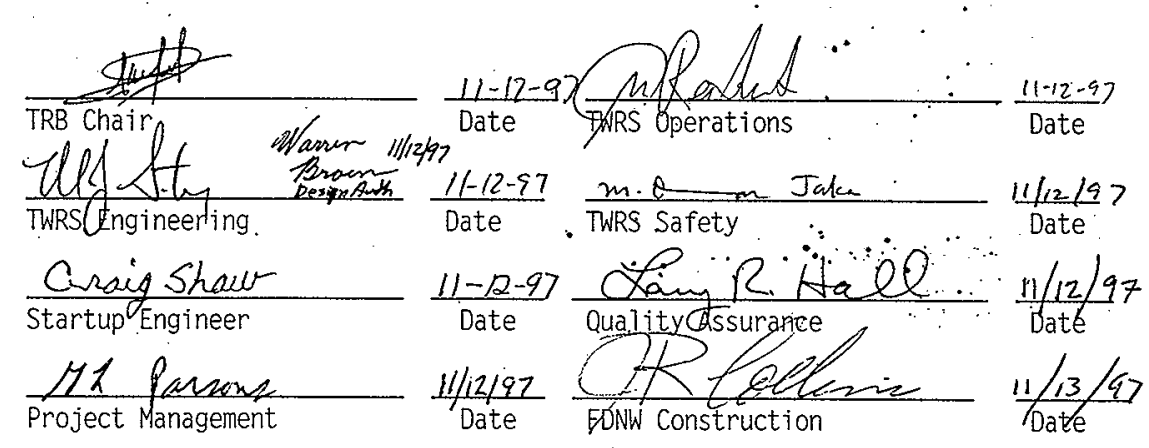




\section{TABLE OF CONTENTS PAGE}

1.0 PURPOSE

2.0 INFORMATION

2.1 SCOPE

2.2 TERMS AND DEFINITIONS

2.3 RESPONSIBILITIES

2.4 CHANGE CONTROL

2.5 EXCEPTIONS

2.6 REFERENCES

2.7 ENVIRONMENTAL.

2.8 SAFETY

2.9 RADIATION AND CONTAMINATION CONTROL.

2.10 QUALITY ASSURANCE

2.11 GENERAL INFORMATION

2.12 LIMITS AND PRECAUTIONS

\section{0 RECOROS}

4.0 PREREQUISITES

5.0 PROCÉDURE

6.0 ACCEPTANCE CRITERIA

\section{ATTACHMENTS}

Attachment A Attachment B Attachment $C$ Attachiment D Attachment $E$ Attachment $F$ 


\subsection{PURPOSE}

1.1 This procedure has been prepared to verify the Cross Site Transfer System Flush water System operates in accordance with system design.

\subsection{INFORMATION}

\subsection{SCOPE}

Temporary hardware will be installed to by-pass Tank $302 C$ and use a 4000 to 8000 gallon tank for testing (tank size depends on availability). Tank $302 \mathrm{C}$ is contaminated and its use would contaminate the flush system.

2.1.1 This procedure will demonstrate the operation of the following components in the the Flush Water System:

- Flush Water Pump . .

- Chemical Addition Package (including drum heater)

- Flush Tank Sump Pump. -

- Circulation Heater Package

- $2.1 .2^{\circ}$ This test will demonstrate the operation of system interlocks and controls both local and remote. The test will a 7 so demonstrate and record the equipment's performance capabilities as it is installed in the field.

\subsection{TERMS AND DEFINITIONS}
2.2 .1
PCU - Process Control Unit
2.2 .2
HS - Hand Switch
2.2.3 MCS - Monitoring and Control Station
2.2 .4
HV - Hand Valve
2.2 .5
PI - Pressure Indicator
2.2.6 T - Prefix used to designate temporary equipment

\subsection{RESPONSIBILITIES}

2.3.1 The Construction Forces craft personnel are responsible for:

- Providing assistance during the test.

- Corrective actions required on equipment. 
2.3.2 Test Director responsiblities:

- Safe and productive accomplishment of the tests necessary to achieve startup.

- Ensure safe working conditions and practices.

- Ensure compliance with test documents and Technical Safety Requirements documents (TSRS) during testing.

- Communicate and coordinate the tests with the Tank Farm Shift Managers.

- Ensure appropriate review/approval of any modifications to test procedures are completed prior to returning to work

- Direct line of communication and centralized point of control.

- Conducts pre-job planning meeting.

- Scheduling/rescheduling of the test as required.

- Delegates any of the above responsibilities as needed to a deputy.

2.3.3 The Engineering Personnel responsibilites:

- Ensures the equipment found in Step 4.7 of "this procedure is available.

- Conducting pre-job system waikdown.

- Recording equipment status and data per this procedure.

- Directing preoperational testing

- Providing technical support during testing.

- Providing programming support during testing.

- Forcing data in PLC program during testing.

- Recording data exceptions and other notes as required on the POTP Data Sheets.

- Review test documents to validate acceptance

- Prepare post testing documents

2.3.4 Operations Personnel responsibilities:

- Observing testing actịvities for.training purpöses.

- Properly disposing of water at the completion of. test. 


\subsection{CHANGE CONTROL}

2.4.1 Test procedure administrative or editorial changes required during testing may be accommodated as exceptions in the released test report, if the changes will not affect operating facility safety, function, or performance and will not compromise or influence test data.

Requirement changes, changes to acceptance criteria, or changes to Danger. Caution. Special Precautions, or other safety or environmental instructions in test procedures prepared as supporting documents must be made by engineering change notice.

\subsection{EXCEPTIONS}

2.5.1 Exceptions to results or to the test procedure wi 77 be given a sequential number and recorded on Attachment $E$. Test Exception log sheet. A test exception report, Attachment $D$, will be filled out to record and disposition each test exception.

\subsection{REFERENCES}

2.6.1 The following documents were used to write or are referenced in this procedure:

- Project.W-058 Startup Test P1an, WHC-SO-W058-SUP-002

- H-2-822400, P\&ID Legend

- H-2-822409, P\&ID Water Flush System

- H-2-824451. Electrical 252-S Substation One-Line Diagram

- H-2-822500, Sh.2 \& 3. Electrical Partial Plan \& Details "SY" Tank Farm

- H-2-822502, Sh. 1 \& 2, Electrical Elementary Diagrams Flush System

YS-058-Y82. Logic Diagram Miscellaneous Interlocks

- Vendor File 22798 - "Hydroflo" Chemical Feed System

- Vendor File 22798 - "Gould" Flush Pump

- Vendor File 22798 - "Indeeco" Circulation Heater Package

- Calcualtion No. W058-P-050 Sodium Hydroxide Addition 


\subsection{ENVIRONMENTAL}

2.7.1 Spills of hazardous materials should be reported to Environmental Reports group at 373-4942.

\subsection{SAFETY}

Warning - Hot. $140^{\circ} \mathrm{F}$, water will be used during testing: special attention shouid be given to avoiding hot piping and hoses.

Operators should be aware of the possibility of. spiders.

coming into contact with poisonous snakes and

2.8.1 The following administrative procedures control work. performed in this procedure:

- Safety: HNF-PR0-074 thru -096 and HNF-PRO-100 thru 105.

- Industrial Hygiene: HNF-PR0-110, -111, $-115,-119$ thru -121.

- Tank Farm Health and Safety. P1an (HASP), WHC-SD-WM-HSP-002

\subsection{RADIATION AND CONTAMINATION CONTROL}

2.9.1 The work covered by this procedure is performed outside of the tank farm and does not require entry into a radiation/contamination control area.

\subsection{QUALITY ASSURANCE/QUALITY CONTROL}

2.10.1 № Quality Assurance witness or hold points are required in this procedure. Quality Assurance shall review and. approve the test procedure, the final test report and the disposition of al1 test exceptions. LMHC QC will witness

$\therefore \quad \therefore \quad \therefore$ testing performed under this POTP.:

2.11 GENERAL INFORMATION

2.11.1 Al1 Measuring and Test Equipment (M\&TE) used during performance of this procedure to collect qualitative data 
with the exception of timing devices shall meet the following requirements:

- Be within its current calibration cycle as evidenced by an affixed calibration label.

- Be capable of desired range.

- Have an accuracy (consistent with state-of-the-art limitations) equal to or greater than the accuracy specified in the procedure.

2.11.2 Timing measurements shall be made with conmercially available time devices.

2.11.3 All readings are to be taken and recorded for each. location where the capability exists (i.e. : rocal : instrument, PCU, MCS). 


\subsection{LIMITS AND PRECAUTIONS}

2.12.1 If during performance of this procedure, any of the following conditions are found, immediately notify the Test Engineer:

- Any equipment malfunction which could prevent fulfillment of it's functional requirements.

- Personnel error or procedural inadequacy which could prevent fulfillment of procedural requirements.

The Test Engineer may choose to stop work and place equipment in a safe condition based on the significance of the malfunction, error or inadequacy.

2.12.2 The Test Engineer has overall control of the testing process and change authorization for this procedure. The Test Engineer is responsible for running the test, data collection. and ensuring compliance with all requirements in this procedure.

2.12.3 Contact Test Director for additional instructions if changing plant conditions affect work or delays in work extend past end of shift.

2.12.4 If any waste is generated during performance of this instruction consult Facility/Plant/Area Hazardous Waste Coordinator for specific instructions to ensure compliance with HNF and DOE environmental standards, as applicable. for disposal.

2.12.5 Comply with FONW and plant/facility specific lock and tag or over-tagging requirements, as applicable.

2.12.6 Steps in this POTP may be performed out of sequence at the direction of the Test Engineer and Test Director.

\subsection{RECORDS}

3.1 This procedure as weil as a i completed attachments/appendices are kept as a permanent record. Test report will be issued to doucument results in accordance with HNF-PRO-446:

\subsection{PREREQUISITES}


Uniess otherwise specified, prerequisite actionswill be performed in this order.

4.1 The following equipment has been prepared for operation in accordance with vendor manuals:

4.1.1 Chemical Addition Package, inçuding calibration column.

4.1.2 In-7ine Heaters.

4:1.3 Flush Pump.

4.1.4 Sump Pump.

4.1.5 Instrumentation: Flowmeters, thermometers, pressure gages.

Test Engineer: Cuning Shaw

4.2 Perform a walkdown inspection of the systems tested and the temporary hardware and configuration needed by this procedure.

Test Engineer: Cuai Shase

4.3 All open items have been evaluated and verified to mot affect the performance of this POTP (Quality Assurance Nonconformance Reports, Construction Punch Lists, outstanding Engineering or Field Change Notices, Startup-originated Design Change Requests, Test Deficiency Reports, and Master System Punch List items).

* Sas Es Test Engineer Suan Shaw $11-21-97$

4.4 Communications between the control room and field test personnel has been verified.

Test Director Cmaigshur $11-21-97$

4.5 The official copy of this POTP and all other copies that will be used during the test have been verified to be the latest revision.

Test Engineer Araig-Shaw $1 /-2 /-9$ ?

4.6 Perform a pretest briefing for all personmel irvolved in the performance of this test.

Test Director

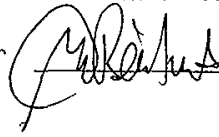

4.7 All personnel who will be involved with this procedure have. provided the required signature verification information in Attachment $B$.

Test Engineer: Cunigh Shew $11 \cdot 21-9 j$.

4.8 The test engineer has verified, by review of the tag $\log$ and $a$ walkdown of the systems being tested, that components within and including the test boundary have been "blue" tagged as appropriate. 


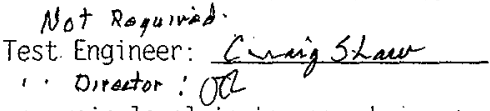

4.9 VERIFY pump P-3100A bearing oil reservoir level is in accordarice with the manufacturer's recommendation.

Test Engineer: Cunaighnow

\subsection{EQUIPMENT/INSTRUMENTS}

Supplied by Test Engineer, as needed, unless otherwise noted.

4.10.1 Clamp-on Ammeter: 0-40 Ampere.

Manufacturer: Amprobe. Model No.
$817-45-02-004$
Lat $4.20-22$
New
Serial No. $250-45-52.038$ Calibration Date
Calibration Due Date $12-9-97$
4.10.2 Multi-meter $0-480 \mathrm{~V}(\Delta-750$ VAL)
Manufacturer: Eluke Model No. 822413
Serial No. $950-45-08-028$.Ca7ibration Date $8-\frac{86.92}{0.628}$
Calibration Due Date $\varepsilon-6-q z$
4.10.3 Ohmmeter (OHM): Quantity of 2 required.
Manufacturer: Elake Model No.8024
Serial No. $950-45-08-0 \times$ Calibration Date $8-6-97$
Calibration Due Date $8-6-97$
4.10.4 Calibration Column:
Maufacturer: Hydrofio - Model 14303-1
Serial No. nome

\subsubsection{Vibration Meter}

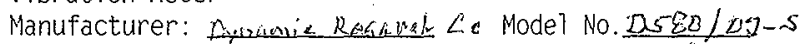
Serial No. 476.3/48.15 Calibration Date $11-24-47$
Calibration Due Date 11-24-98

4.10.6 Temporary test tank ( 4000 ga1), assorted hoses, pipes, fittings, strainers, as per Attachment $F$.

4.10.7 55 gallon drum of water

4.10.8 Contact Pyrometer

Manufacturer: Eluke

Mode] No. 52

Serial No. 4695429 Calibration Date $5-1-97$

Calibration Due Date $5-1-98$ 


$$
-30^{\circ} \mathrm{Hg} \text { to } 60 \text { psig } 201.2298
$$

4.10.9 Pressure Gage - 25 to 50 psig. 1/2" mpt

Manufacturer: Wika Model No.30/0/60

Serial No. Bat-PG-Dal Calibration Date 11-17-97

Calibration Due Date $11-12-28$

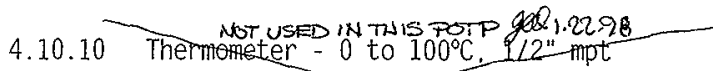

Manufacturer: Calibration Date No.

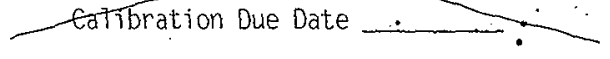

$$
\text { (c5) } 0058-378(t)
$$

5.0 PROCEDURE

5:1 Preoperational testing shall be performed using Attachment $A$ of this procedure.

REF TE-OO4 $\sim$ RESTRICED FLOW METER RANGE PREVENTED DATA COLIECTIOY FOR THE FLLL RANGE OF THE PUMP. 4 RRD DATAA FER PUMP PER FORMANCE

6.0 ACCEPTANCE CRITERIA AT TILE OPERATING PONT WAS COULETED AND TAE 1 PUMP DID MEA TAE STATEO REQUUREMAENT

6.1 Determine the Flush water Pump performance curve as installed; at 1.22 .98 $140 \mathrm{gpm}$ the head must be at least $240 \mathrm{ft}$ per vendor information.

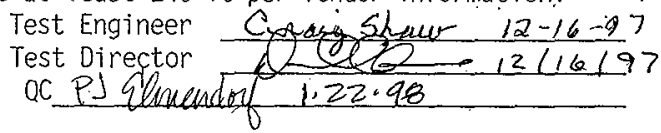

6.2 Verify the Flush water System Sump Pump is operational.

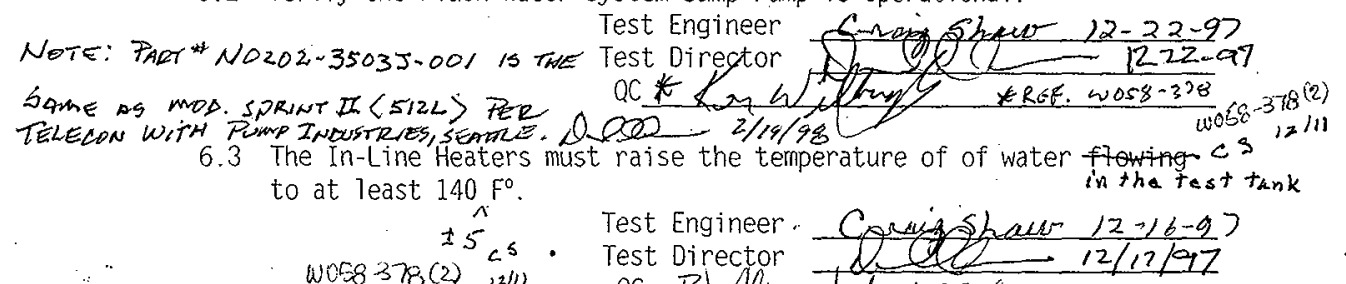

Test Engineer

Test Director

OC $*$

w058 $378(2)<5<$

Test Engineer
Test Director QC 1.22 .48

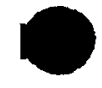

6.4. The Chemical Addition Pump capacity has been verified to deliver 12.4. gph at water flow of $170 \mathrm{gpm}$. The chemical addition $\pm 5 \%$ raw $w 058.376(3)$

HAF -1552 然 $2 / 18 / 98$ $\pi 7$

$$
\text { HNF-1917 Pal8 RevO }
$$


pump shall maintain the corresponding pre-set caustic/water

- injection ratio.

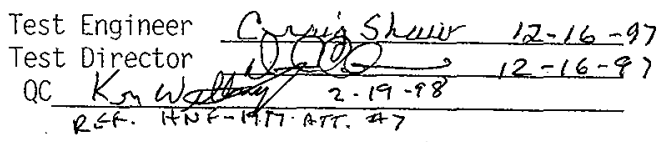

6.5 Local and Remote control devices, instruments and interlocks operate in accordance with design specifications. Specifically: 1) Interlock 18 shuts down pump P-3100 A on low tank level: and 2) Inter lock 19. turns off the heater(s) on the Element Sheath High Limit Controller, the Process High Limit Controller, and Flow Switch. Interlock 19 is provided as part of the vendor package.

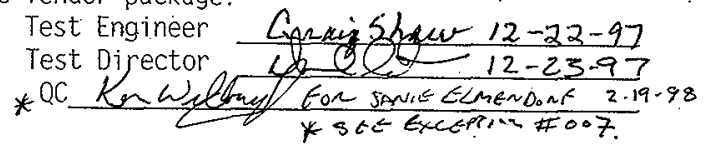


PREOPERATIONAL TEST POTP-001, CROSS SITE TRANSFER FLUSH SYSTEM

Revision No. 0

HNF- 1552

PAGE 1 OF 30

ATTACHMENT A

1.0 - INITIAL CONDITIONS

1.1 VERIFY all system instrumentation in Appendix A is calibrated and has a current calibration tag affixed to each instrument.

Test Engineer: Cunig Shaw

1.2 VERIFY the system is aligned for preoperational testing in accordance with Appendix B.

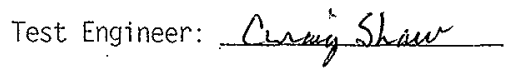

1.3 VERIFY system electrical circuit breakers are aligned in accordance with Appendix $C$.

Test Engineer:

1.4 VERIFY system is configured with the temporary water tank. hoses, and valving as shown in Attachment $F$.

Test Engineer:

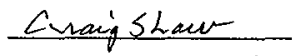

1.5 VERIFY that Hydroflo Chemical Injection Pump is set up per vendor. instructions and temporary test conditions. This includes setting the Back Pressure Valve PRV-302C-3 to 35 psig and installing the calibration column per vendor instructions.

Test Engineer: Cirsig Slow

1.6 VERIFY vibration targets have been attached to pump P-3100A as described in Appendix D-1

Test Engineer: Ciraig Shaw

1.7. STAGE a 55 gallon drum of sanitary water at the Chemical Addition System skid.

Test Engineer: $\frac{\text { Swaigshxw }}{\text { Buckat } 11.20 .97}$

1.8 CONNECT Chemical Addition Pump suction line to the Bucket (c) Dwa56-378

Test Engineer:

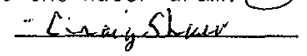

1.9 CONNECT Hydroflo Calibration Column per manufacturers instructions.

Test Engineer: Anaig Shw

4. 10- CONACT Chemical Adtition Punt temporary discharge-line to the water dis shom in Attachent f. 14 (CS) 11-20-97

Q 3058.378 
PREOPERATIONAL TEST POTP.001, CROSS SITE TRANSFER FLUSH SYSTEM

HNF- 1552

PAGE 2 OF 30

Revision No. 0

ATTACHMENT A

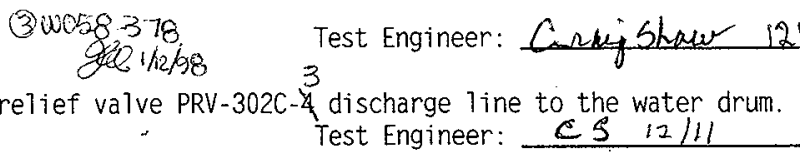

2.0 Chemical Addition System Testing and Calibration with Water

This section will calibrate the flow of the chemical injection pump by means of a factory supplied calibration cylinder. The output of the pump will be manually set to a percentage of its output and the actual flow determined

by timing the flow out of 250 - mit. " Calibration column. SEE TEST LOB DTD 1,22.98

\begin{tabular}{c}
1.11 CONNECT relief valve PRV-302C-4 discharge line to the water drum. \\
Test Engineer: $e^{5} 12 / 11$ \\
\hline
\end{tabular}

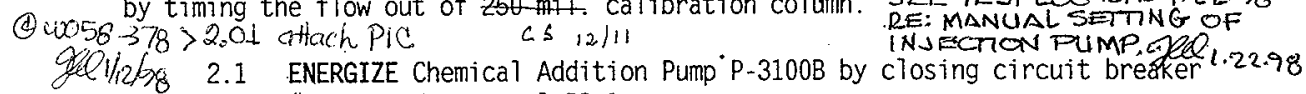
\#3 located in panel PP-1.

2.2 VERIFY Chemical Addition Pump P-3100B STARTS.

Test Engineer: CS 12/11

2.3 OPEN Chemical Addition System injection line vent valve T4, see Attachment $F$.

CS

2.4 CLOSE Chemical Addition System injection line vent valve T4 when water issues from the vent. cs

2.5 STQP Chemica] Addition Pump P-3100B by opening circuit breaker \#3 Wh-058-378 located in panel PP-1. CS

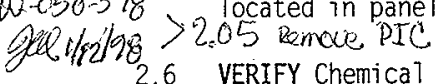

2.6 VERIFY Chemical Addition Pump P-3100B STOPS.

$$
\text { Test Engineer: Curaig Shaw }
$$

2.7 VERIFY Chemical pump calibration column is filled.

Test Engineer:

CS

2.8 Manually set the chemical addition pump P-3100B to $25 \%$ capacity. Test Engineer: cs

2.9 Start (close breaker 3) the chemical addition pump P-3100B and record the time required to empty the calibration column. Seconds

(6) $10056-378$ ate +12198 8.9 [ino increments) $($ tinesc) $] 239 / \mathrm{sec}=3.36 \mathrm{gph}$

26,5 sac $/ 10$ inerament 
PREOPERATIONAL TEST POTP-001, CROSS SITE TRANSFER FLUSH SYSTEM

2.10 Stop (open breaker 3)the chemical addition pump P-3100B.

Test Engineer:

CS

2.11 Refill the chemical-pump calibration column.

$$
\text { Test Engineer: } \frac{\sum S}{12 \mathrm{ma}}
$$

2.12 Manually set the chemical addition pump P-3100B to $50 \%$ capacity.

Test Engineer: CS

2.13 Start (close breaker 3)the chemical addition pump P-3100B and record the time required to empty the calibration column. Seconds 11.75 sectio cuenements

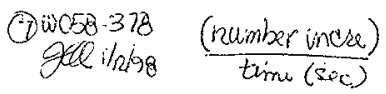

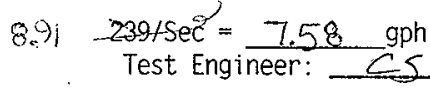

2.14 Stop (open breaker 3 ) the chemical addition pump P-3100B. Test Engineer: CS

2.15 Refill the chemical pump calibration column. Test Engineer: CS

2.16 Manua77y set the chemical addition pump P-3100B to $75 \%$ capacity. Test Engineer: CS

2.17 Start (close breaker 3)the chemical addition pump P-3100B and record the time required to empty the calibration column. seconds $2.6 \mathrm{sed} / 10$ minment

(8) Wove-370 (numberincrements) $897-239 / \mathrm{sec}=11.72 \mathrm{gph}$ QU $1 / 12 \%$ Timol $(\mathrm{sec})$ Test Engineer: CS

2.18 Stop (open breaker 3) the chemical addition pump P-31.00B. Test Engineer: $C S$

2.19 Refill the chemical pump calibration column.

T.est Engineer: cS

2.20 Manually set the chemical addition pump P-3100B to $100 \%$ capacity. Test Engineer: $\propto s$ 
PREOPERATIONAL TEST. POTP-001, CROSS SITE TRANSFER FLUSH SYSTEM

HNF- 1552

Revision No. 은

ATTACHMENT A

PAGE 4 OF 30

2.21 Start (close breaker 3) the chemical addition pump $\mathrm{P}=3100 \mathrm{~B}$ and record the time required to empty the calibration column. Seconds $5.8 \mathrm{sec} / 10$ unimamante.

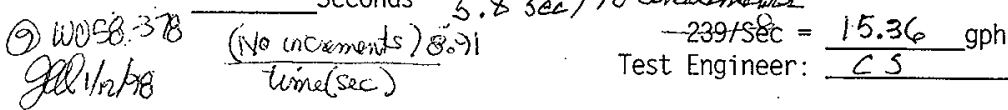

2.22 Stop (open breaker 3 ) the chemical addition pump

Test Engineer:

P-3100B.

CS

FUNCTIONAL TEST OF DRUM HEATER, NO ACCEPTANCE CRITERIA

2.23 Using a calibrated pyrometer. MEASURE and RECORD temperature of the water drum at the Chemical Addition skid.

2.23.1 Water Drum temperature $56{ }^{\circ} \mathrm{F}$ 9:30Time 11-18-67

Test Engineer:

2.24 ENERGIZE the drum heater at the Chemical Addition skid.

2.25 MONITOR drum temperature with pyrometer.

2.26 VERIFY an increasing drum temperature, measure at end of shift (the rest of testing may proceed while drum is warming).

2.26.1 Water Drum temperature $94 \quad{ }^{\circ}$ F 10:15 Time $11-14-97$

Test Engineer: Ainghiow

2.27 DE-ENERGIZE the Chemical Addition skid drum heater.

Test Engineer:

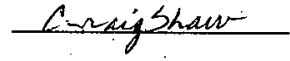

3.0 Temporary Water Tank Fill Testing and Chemical Addition Ratio Test This section of the test will demonstrate the flowmeter measuring the water that filis the flush tank reads out both locally and at the MCS. This section also demonstrates that the chemical injection pump maintains the ratio. set at MCS, between fill rate and chemical injection. In this test a tanker truck will be filled rather that tank $302 \mathrm{C}$

To verify the ratto $(823.1$ )of service to caustic injection (25\% $\mathrm{NaOH}$ ) divide the gpm displayed by FEIFT $3026-1$ by 170 and multiply by 19.3 to calculate the number of seconds expected to empty the $250 \mathrm{ml}$ eatibration cylinder. (10) wo58 as 
PREOPERATIONAL TEST POTP-001, CROSS SITE TRANSFER FLUSH SYSTEM

3.1 SET at the MCS the ratio of service water to caustic addition at

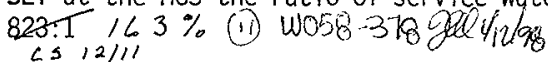

3.2 CLOSE VaTVE TV-1

3.3 OPEN Valve TV-2

Test Engineer: $\quad$ CS

Test Engineer: $\subset S$

Test Engineer: $C S$

3.4 VERIFY flowmeter FE/FT-302C-2 is programmed to display units of gallons per minute (gpm).

Test Engineer:

3.5 RESET FQI -302C-2 to zero at the MCS screen.

Test Engineer:

CS

3.6 RECORD the following data:

Temporary Water Tank level

Seprice Water totalizer.

Service Water Pressure

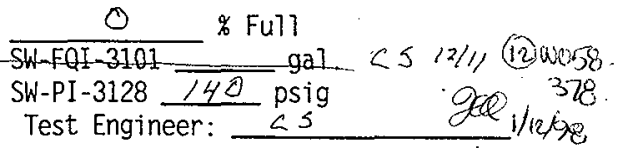

3.7 SLOWLY OPEN Flush Water Tank fill Tine isolation valve $V-3186 A$ to establish a flowrate of approximately 50 gpm.

3.8 RECORD the following data:

Service-Water-Pressure

Water Flush Tank fill flowrate

SW-PI-3128

FIC-302C-2 50 gpm

Test Engineer:

(14) $w 058.378$ ge $1 / 12 / 98$

$5 I C-302 C-2$

3.9 VERIFY AND RECORD Water Flush Tank flowrate display on the ISS equivalent to the display on the local flowmeter. $+/-3 \%$

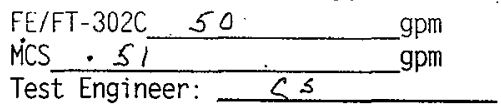

3.10 VERIFY chemical addition pump P-3100B is off.

Test Engineer: _._ $C S$

3.11 Refill calibration column. $a^{6}$ 
PREOPERATIONAL TEST POTP-001, CROSS SITE TRANSFER FLUSH SYSTEM

HNF-1552

PAGE 6 OF 30

Revision No. 0

ATTACHMENT A.

Test Engineer: ¿ $\mathrm{S}$

3.12 Valve calibration column to suction of chemical addition pump $P$ $3100 \mathrm{~B}$.

Test Engineer: $S \mathbb{S}$

3.13 START Chemical Addition Pump P-3100B by closing circuit breaker \#3 located in panel PP-1. EXCEPTION\$10

3.14 VERIFY Chemical Addition Pump starts.

Test Engineer:

3.15 RECORD the following data:

3.15.1 Water Flush Tank fill flowrate FIC-302C-2 51 gpm

3.15.2 Chemical Addition Pump flowrate Empty-Ga7,- column: $\mathrm{Sec}^{2}$ -

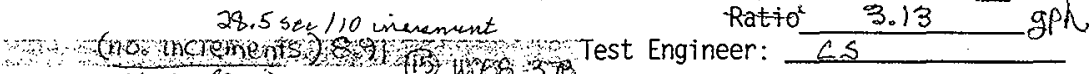

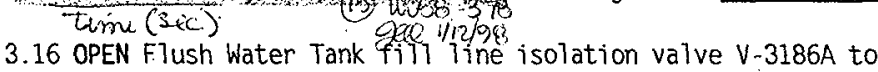

establish a flowrate of approximately $100 \mathrm{gpm}$.

3.17 RECORD the following data:

(16) Wo58-378-Service Water Pressure-SW-PI-3128

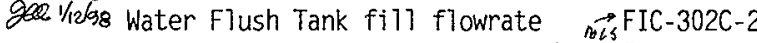

Test Engineer:

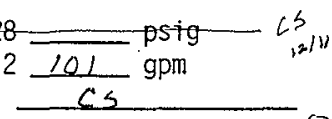

FIC-302C-2 (17)w058. 378

3.18 VERIFY AND RECORD Water Flush Tank flowrate display on the MES is $1 / 12198$ equivalent to the display on the local flowmeter. $+1-3 \%$

w058-378.(18) FEIFT-302C-210l gpm

gea $1 / 12198$ MCS

Test Engineer:

gpm

$\left.\left.c^{5} i^{\prime \prime \prime \prime} s^{x}+a^{x}\right)^{2}\right)^{2 \prime \prime}$

Q)

C.5

3 ST Stop chemical addition pump P-3100B by opening breaker \#3.

Test Engineer:

es

3.20 Refill calibration column.

Test Engineer: \&S

3.21 Valve calibration. column to suction of chemical addition pump P3100B.

Test Engineer: 63

3.22 START Chemical Addition Pump P-3100B by closing circuit breaker \#3 
PREOPERATIONAL TEST POTP-001, CROSS SITE TRANSFER FLUSH SYSTEM

Tocated in panel PP-1.

3.23 VERIFY Chemical Addition Pump starts.

Test Engineer: $\mathrm{CS}$

3.24 RECORD the following data:

3.24.1 Water Flush Tank fill flowrate

3.24.2 Chemical Addition Pump flowrate 12.9 sec 110 increments (no increments) $8.91=\div$ gph Test Engineer time (sec) (19) wos8-378ge2 1/12/98

FIC-302C-2 121 gpm

Empty Cal-Colum - Sece Ratio Q.91 gph

3.25 SLOWLY OPEN Flush water Tank fill line isolation valve $V-3186 \mathrm{~A}$ to establish a flowrate of approximately $150 \mathrm{gpm}$.

$$
170 \underset{12111}{250} \text { w058-378 } 262.1 / 196
$$

3.26 MEASURE AND RECORD the following data:

Sepvice-water Pressure

$\mathrm{SW}-\mathrm{PI}=3128$

Water Flush Tank fill flowrate

Test Engineer:

3.27 VERIFY Water Flush Tank flowrate display on the MCS is equivalent to the display on the local flowmeter. $+/-3 \% 17.3$

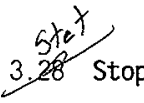

Stop chemical addition pump

Test Engineer:

cs

Test Engineer: $\operatorname{cs}$

3.29 Refill calibration column.

Test Engineer: $\mathrm{CS}$

3.30 Valve calibration column to suction of chemical addition pump $\mathrm{P}$ $3100 \mathrm{~B}$.

Test Engineer: $\mathrm{CS}$

3.31 START Chemical Addition Pump P-3100B by closing circuit breaker \#3 located in panel PP-1.

3.32 VERIFY Chemical Addition Pump starts.

Test Engineer:

3.33 RECORD the following data:

3.33.1 Water Flush Tank fill flowrate FIC-302C-2 171.. gpm

3.33.2 Chemical Addition Pump flowrate Emy ca7. colum sece

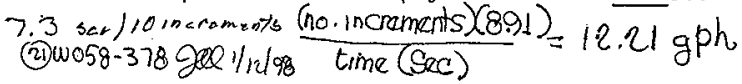


PREOPERATIONAL TEST POTP-001, CROSS SITE TRANSFER FLUSH SYSTEM

HNF - 1552

PAGE 8 OF 30

Revision No. 0

ATTACHMENT A

Test Engineer:

$i^{5}$

3.34 SLOWL MOPEN Flush water Tank fill line isolation valve $V-3186 \mathrm{~A}$ to

: establish a flowrate of approximately $200 \mathrm{gpm}$.

ch

3.35 RECORD the following data:

Service Water Pressure

Water Flush Tank fill flowrate

SW-PI-3128

FIC-302C-2

psig gpm

Test Engineer:

\section{$c^{5} /$}

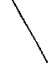

Test Engineer:

3.36 VERIFY water Flush Tank flowrate display on the MCS is equivalent to the display on the local flowmeter. $+/-3 \%$

Test Engineer:

3.37 Stop chemical addition pump P-3100B by opening breaker \#3.

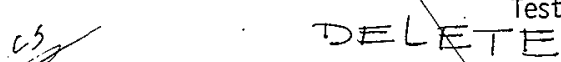

Test Engineer:

3,38 Refill calibration column.

3.89

Valve calibration column to suction of chemical addition pump P$3100 \mathrm{~B}$.

3. 50 START Chemical Addition Pump P-3100B by closing circuit breaker \#3 Test Engineer:

Test Engineer:

located in panel PP-1.
3.4. VERIFY Chemical Addition Pump starts.

3. RECORD the following data:

3.42.1 Water Flush Tank fill flowrate

3.42.2 Chemical Addition Pump flowrate

o-(22) $10058-378$ gee $1 / 12 / 98$

Test Engineer:

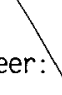

: 
PREOPERATIONAL TEST POTP-001, CROSS SITE TRANSFER FLUSH SYSTEM

Revision No. 0 HNF -1552

PAGE 9 OF. 30

ATTACHMENT A

3.45 VERIFY temporary flush tank is full. 100 \% Full 8099 c5
$12 / 8$

Test Engineer: Cuaig SLaw

4.0 Flush Pump P.3100A

This section of the test measures the characteristic curve at six points for the $20 \mathrm{hp}$ flush pump. At each test point electric data of amps and volts is measured for each motor phase and the pump vibration is measured. This test will verify the pump meets the process requirement of delivering $140 \mathrm{gpm}$ at $240 \mathrm{ft}$ as claimed by the vendor. This test also gathers benchmark data on pump performance for future use.

This wi77 require a permit to work on an energized circuit!

Adjust software to by pass tank low laval $(\angle 2 T-302 C-1)$. (30) wo58. 378

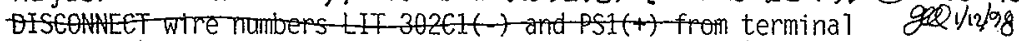
block PCU-1-781 lerminats.37-38-located in PGU $=1$.

4.2 COAHECT the Process-Inst tument-Eal ibrator (PIC) to PCU-1-TBI teminats 37 and 38.

(3) $1058-37898 v_{12} 98$

4.3 SET the PIC for an of $16 \mathrm{~mA}$.

4.4 CLOSE the Flush Pump disconnect located at the local motor controller.

Test Engineer: Cuaighaw

4.5 VERIFY valve V-3186A closed.

Test Engineer: Cuarighuer \& 45

4.6 VERIFY Valve V-3187A closed.

4.7 VERIFY valve $V-3188 D$ open. .

Test Engineer: Curasi Shaw $r^{2 s / 12 / 8}$ Test Engineer: Cuais SLwe $\because 65 / 12 / 8$

4.8 VERIFY vaTve $V-3188 \mathrm{C}$ open.

Test Engineer: $05 / 2 x / x$ 
PREOPERATIONAL TEST POTP-001, CROSS SITE TRANSFER FLUSH SYSTEM

Revision No. e

4.9 VERIFY the Flush Pump motor controller indicates pump is stopped, $-c^{S}$ both MCS and local.

Test Engineer: Cuagh Shaw .

4.10 VERIFY the following on the MCS for flush pump P-3100A:

4.10.1 - The STOP button under the label "Pump Controls" CS 97 on the P $3100 \mathrm{~A}$ screen is illuminated.

$11^{-26}$ (23) w-058.378ge81/268 Test Engineer: Cusag SLaur
4.10 .2
Pump Status OFF button is illuminated.
Test Engineer: Cunaig Sham

25
4.10 .3
P-3100A FAILURE button is NOT i17uminated.
Test Engineer:

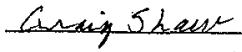

4.11 VERIFY flowmeter FE/FT-302C-1 is programmed to show flow rate on its local digital screen and the MCS, in units of gałlons per minute (gpm).

\section{Test Engineer: Cvaig Shaw}

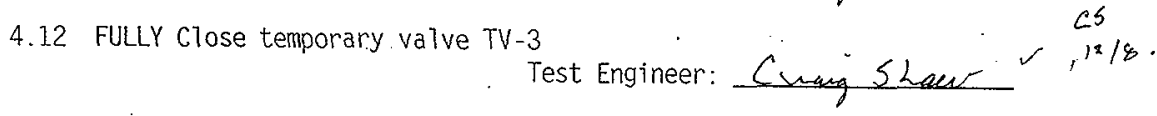

\section{"EILLING AND VENTING"}

4.13 FULLY OPEN temporary valves TV-1 and TV-2 in order to fill pump suction piping with water from the temporary test tanker.

Test Engineer: Curaig Shaw

4.14. FULLY OPEN V-31888 to vent the air from the system.

Test Engineer: Cunaig Shaw

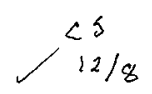


PREOPERATIONAL TEST POTP-001, CROSS SITE TRANSFER FLUSH SYSTEM

Revision No. 0 HNF 1552

ATTACHMENT A

PAGE 11 OF 30

Fest-Engineer:___ $<51218$

Note: Pump operating curve is documented in the following steps. When recording pump shut-off head, minimize the length of time that $V-31878$ is closed. Step 4.18, closing $v-3187 B$, measures pump data at shutoff conditions.

4.19 CLOSE Flush System recirculation valve V-3187B.

4.20 RECORD required data for Flush Pump P-3100A in Appendix D-1 data. sheet:

Test Engineer: Cuarg Shaw 12/8

4.21 OPEN Flush System recirculation valve $V-31878$ to establish a system flowrate of approximately $50 \mathrm{gpm}$.

4.22 RECORD data for Flush Pump P-3100A in Appendix D-1 data sheet:

Test Engineer: Cwaig Shaw 12/8

4.23 ADJUST Flush System recirculation valve $V-3187 B$ to establish a system flowrate of approximately $100 \mathrm{gpm}$.

4.24 RECORD data for Flush Pump P-3100A in Appendix 'D-1 data sheet:

Test Engineer: Curaig 5Lm 12/8

4.25 ADJUST Flush System recirculation valve $V-3187 B$ to establish a system flowrate of approximately $140 \mathrm{gpm}$.

4.26 RECORD data for Flush Pump P-3100A in Appendix D-1 data sheet:

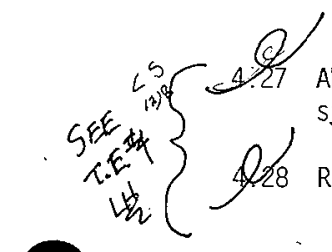

Test Engineer: Curaig Sheur 12/8

ADJUST Filash System recirculation valve $V$-3187B to establish a system flowkate of approximately $200 \mathrm{gpm}$.

\section{TDECPE}

RECORD data for Fush Pump P-3100A in Appendix D-1 data sheet:

Test Engineer:

(26) wo $58-378 \mathrm{ggl}$ 1/198 
PREOPERATIONAL TEST POTP-001, CROSS SITE TRANSFER FLUSH SYSTEM

Revision No. $\underline{0}$

ATTACHMENT A

PAGE 12 OF 30

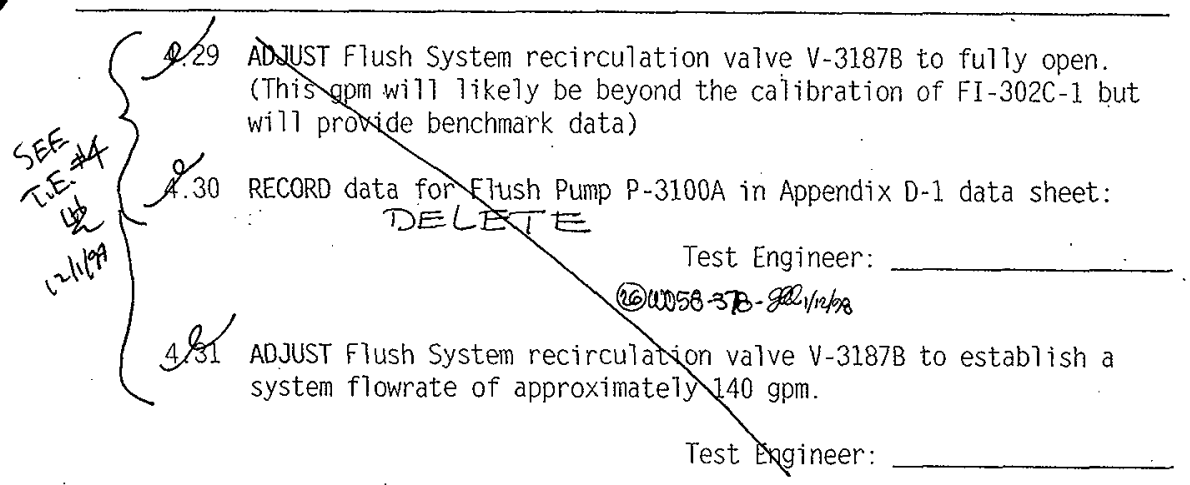

4.32 PRESS the Flush Pump P-3100A local control STOP button.

VERIFY Flush Pump P-3100A STOPS.

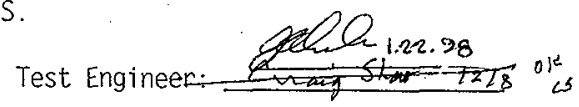

4.33 VERIFY Pump Status OFF button is illuminated on the MCS.

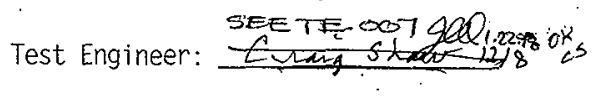

4.34 START Flush Pump P-3100A from the remote control START button at the MCS.

4.35 VERIFY Flush Pump P-3100A STARTS.

$$
\text { Test Engineer: Cuang Shaw }
$$

4.36 VERIFY Pump Status ON button is illuminated on the MCS.

$$
\text { Test Engineer: Cmaj Shaw }
$$

This next step domonstrates Tow tank Tevel inter lock 18 .

4.37 SIMULATE a flush tank level of 5 feet at LIT-302C-1.

(32) Wo58-378 Refep back to $\sec 4.1,4.2,4.3$ where the PIC output was set at $16 \mathrm{~mA}$ ger regs to allow plimp $P$-3100A to-operate:

Removed software over mide on low Tanteloval lesed earlier

To do curva.

$$
H N+1017 \text { PQ } 31 \text { RevO } 25 \text { of } 51
$$


PREOPERATIONAL TEST P0TP-001, CROSS SITE TRANSFER FLUSH SYSTEM

HNF - 1552

PAGE 13 OF 30

Revision No. $\underline{0}$

ATTACHMENT A

4.38 SET PIC for an output of $8 \mathrm{~mA}$. 2,5 mosedesect

Test Engineer: Enaig Shaw 12-8

4.39 VERIFY Flush Pump P=3100A STOPS. Interlock 18 verified to stop pump on low tank level.

Test Engineer: Craig Shew 12-8

4.40 VERIFY alarm indication is shown on MCS.

Test Engineer: Curaig Shaw 12-8

4.41 VERIFY Pump Status on MCS indicates OFF. ExeAption $\$ 8$

Test Engineer: $\frac{\text { Curay Shrur pew 12-8-97 }}{\text { Resclution of exception }{ }^{2} 8}$

\subsection{Circulation Heater Testing}

This section energizes the heaters and demonstrates their capability of heating the water to $140^{\circ} \mathrm{F}$. This section also verifies and demonstrates "Interlock 19" that was supplied by the vendor as part of the heater package. The Interlock 19 turns off the heater(s): 1) Element Sheath High Limit Contro7ler, $375^{\circ} \mathrm{F}$, the Process High Limit Control7er, $180^{\circ} \mathrm{F}$,

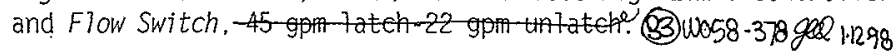

Adjust software to bypass tank 3026 low leved in put from LIT-302C-1 (34) WO58-378

5.1 SET the PIC for an output of 16 mA. (This-allows pump-P-3100A to operate)(See Sec 4.1-4.3 Software overiden

5.2 POSITION VALVES

5.2.1 Temporary Valve TV-1 open

5.Z2.2 Temporary Valve TV-2 open

$5.2 .3 \mathrm{~V}-3187 \mathrm{~B} 1 / 8$ open

$5.2 .4 \mathrm{~V}-3188 \mathrm{C}$ closed

$5.2 .5 \mathrm{~V}-31880$ closed

$5.2 .6 \mathrm{~V}$-3188E open

52.7 V-3188F open

$52.8 \mathrm{~V}-3188 \mathrm{G}$ open

Test Engineer: CS $12-9$

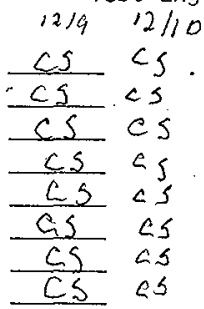


PREOPERATIONAL TEST POTP-001, CROSS SITE TRANSFER FLUSH SYSTEM

HNF- 1552

Revision No. 0

ATTACHMENT A

PAGE 14 OF 30

$5.2 .9 \mathrm{~V}-3188 \mathrm{H}$ open

5.2.10 V-3187A closed

5.2. 11 Tempoarary Valve TV-3 closed

5.2. 12 V-3186A closed

$12 / 912 / 10$

(30)

is.9 $_{129} 5.2 .13$ Closed disconnect P3100A ES 12/9 (35) wo5t Engineer: Cuag shaw gew

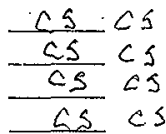

5.3 START Flush Pump P-3100A from the remote control START button at the MCS. SEE EXCEPTION TE-CO7 CONTROLLEO LOCALLY 1.22 .98

1.1290

5.4. Adjust $V-31878$ until a flow of $140+/-10$ gpm is show on FE/FT

$c^{5}$ $12-9$ 302C-1. CS Rla

Foiled CS 1219

5.4.1 Stop pump locally 5.4.2 Start pump ramote Gpm $138<512 / 9$

Test Engineer: cs $12 / 9$

5.5 Operate at this flow for 15 minutes to purge air from heaters.

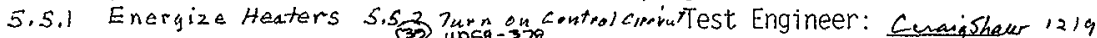

5.6 Slowly Close valve $V-3187 B^{405}$ unt $i$ flow switches FSL $302 C-4 A$ \& $4 B$

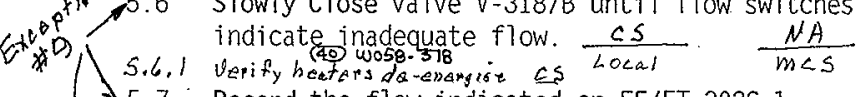

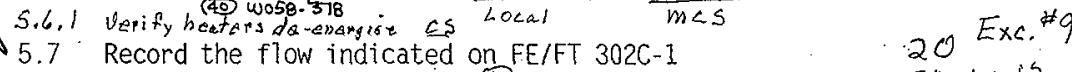

(41) $w_{00} 8-378$

(22 gpm+t $5450-60$ is

Test Engineer: Cuaig Shaw

5.8 STowly Open valve $V-31878$ until flow switches FSL $302 C-4 A$ \& $4 B$ indicate flow.

$\frac{C S}{\text { Local }} \frac{N A}{m C S}$

5.9 Record the flow indicated on FE/FT. 302C-1

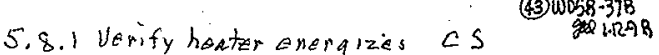

5.10 Adjust flow to $140+/-10$ gpm with $V-3187 B$ as read on FE/FT $302 C-1$

Test Engineer:

: $\{$.

HEATER \#12 per ECM WOS8-340 E.P

5.11 VERIFY Circulation Heater \#12Jocal control switch is in the OFF position.

Test Engineer: cS

5.12 CLOSE Circulation Heater $\# \times 27$ ocal disconnect switch located next to the heater control pane]. es.

5.13 RECORD the following data:

WAE 1552 . 
PREOPERATIONAL TEST POTP.001, CROSS SITE TRANSFER FLUSH SYSTEM

Revision No. 0

5.13.1 Recirc line water temp. (from MCS) TI-302C-2 $58{ }^{\circ}{ }^{\circ}$.

5.13.2 Recirc line water temp.

(local) TE-302C 238 . 58 .

(50) $\operatorname{los}_{0.0} 1.37 .2 \%$

Test Engineer: is $11^{\circ} 2$ Craig Shaw.

This will require a permit to work on an energized circuit!

2 per ECN W-058-340 EA

5.14 ADJUST Circulation Heater $\# \chi$ Process Temperature Controller to approximately $10^{\circ} \mathrm{F}$ below the lowest temperature recorded in Step above. $C S$

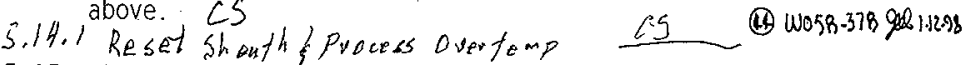
5.15 PLACE Circulation Heater $\# 1_{2}$ control switch in the oN position. $C S$

5.16 VERIFY Circulation Heater \#Z DOES NOT ENERGIZE by observing that the starter for Circulation Heater \#1, does notose.

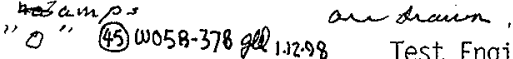

Test Engineer: Cuaig Shaw -

5.17 ADJUST Circulation Heater $\# \alpha^{2}$ Process Temperature Controller to approximately $10^{\circ} \mathrm{F}$ above the lowest temperature recorded in Step 5.10 above.

5.18 VERIFY Circulation Heater $21^{2}$ ENERGIZES by ampenes are drown

5.18 VERIFY Circulation Heater \#1 ENERGIZES by observing the-starter contac for Circulation Heater \#1-chosing. 464058.378 go 1.298 ampar $(300+)$ REFge

i.2298 Test Engineer: Smaig Shar

5. 19 SIMULATE a low inlet flow condition in Circulation Heater \#1 by s lifting the P16 lead at the flow switch terminal block.

5.20 VERIFY Circulation Heater $\# 2$ DEENERGIZES by observing the starter contactor for Cikculation Heater \#1 opening.

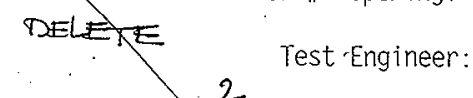

5.21 , PLACE Circulation Heater control switch in the OFF position.

5.22 RECONNECT the P16 lead.

(47) w058-378g2Q1:1208

Test Engineer:

HAF 1552 
PREOPERATIONAL TEST POTP-001, CROSS SITE TRANSFER FLUSH SYSTEM

Revision No. Q

PAGE 16 OF 30

ATTACHMENT A

i. (47) $1058-378$ g8 1.12 .08

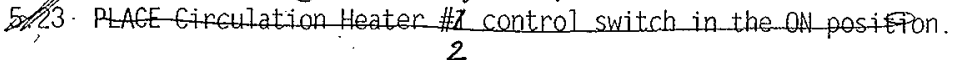

2 per ECN W058-340 E.P

5.24 RE.SET the Circulation Heater \# $\mathcal{A}$ Process Temperature Controller to $\cdot 140^{\circ} \mathrm{F}$.

2

Test Engineer:

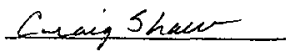

5.25 VERIFY Circulation Heater $\# \chi$ ENERGIZES by observing starter entacter for Circulation Heater \#12closing. is amps $(285)$ are drawn Test Engineer:

Testing Process High Temperature Limit Thermocouple Ref 48 w059-379 2001.12 .98
gemperature Limit Thermocouple

5.26 SET the process high limit controller to $180{ }^{\circ} \mathrm{F}$.

Test Engineer: CS

\section{2}

5.27 PLACE Circulation Heater \#Z control switch in the OFF position. $C S$

5.28 DISCONNECT the type J Process High Limit Thermocouple, TE302C-4C. from tèrminals TC3(Red wire) and TC4 (White wire). CS

5.29 CONNECT the Automated Temperature Calibrator to terminals TC3 and TC4. ¿S

5.30 PROGRAM the thermocouple input instrument for a type $J$ thermocouple. Cs

5.31 PLACE Circulation Heater 2

5.32 VERIFY Circulation Heater \#1 ENERGIZES by observing amperes are drawn. contactor for Eirculation Heatep th elosing. c) ampr (49) W.058-378 9001.12.98 Test Engineer: C.S

5.33 PROGRAM a temperature of $180^{\circ} \mathrm{F}$ on the Automated Temperature Calibrator.

5.34 VERIFY the following:

5.34.1. Circulation Heater $\#$ out let temperature high alarm $\sqrt{ }$ TAH-302E18 annunciates at the MCS. $c^{5}$ outlat $A$ Test Engineer:

Eungis shaw (51) $w 058-378 g 061.12 .98$ 
PREOPERATIONAL TEST POTP-001. CROSS SITE TRANSFER FLUSH SYSTEM

HNF - 1552

PAGE 17 OF 30

Revision No. 0

ATTACHMENT A

\subsubsection{Circulation Heater \#x DEENERGIZES.}

2 per ECN WOS $8-340$ E.P

\section{2}

Test Engineer:

5.35 PLACE Circulation Heater \#A control switch in the OFF position. $C$ S

5.36 DISCONNECT the Automated Temperature Calibrator from terminals TC3 and TC4.

5.37 RE-CONNECT the type $]$ Process High Limit Thermocouple, TE302C-4C, \&S to terminals TC3(Red wire) and TC4 (White wire).

5.38 PLACE Circulation Heater $\# \AA^{2}$ control switch in the ON position. <s

5.39 VERIFY the following:

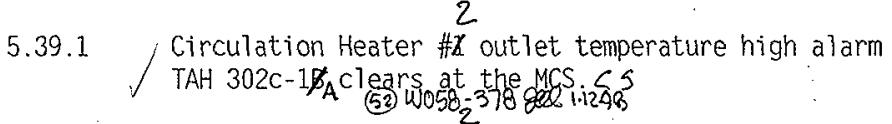

5.39.2 Circulation Heater \#1 ENERGIZES.

Test Engineer:

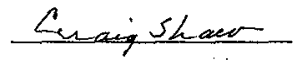

5.40 PLACE Circulation Heater $\#{ }^{2}$ control switch in the OFF position.

Testing Sheath High Tempeature Limit Thermocouple

5.41 DISCONNECT the type J Sheath High Limit Thermocouple. TE302C-4E, from terminals TC5(Red Wire) and TC6(White Wire). CS

5.42 CONNECT the Automated Temperature Calibrator to terminals TC5 and $C^{S}$ TC6.

5.43 VERIFY the sheath high limit controller is set at $375^{\circ} 0^{\circ} \mathrm{F}$.

Test Engineer: CS

5.43 .1 Reset sheath and process over temperature (53) W058.378g01.12.98

5.44 PROGRAM the thermocouple input instrument for a type $]$

thermocouple. cs

2

5.45 PLACE Circulation Heater \#I control switch in the ON position.

2 amperes aredrawn

5. 46. VERIFY Circulation Heater \#Z ENERGIZES by observing the-starter for Circulation Heater \#1 closing. (34) w058-378 gel 1.1298 amps 
PREOPERATIONAL TEST POTP-001, CROSS SITE TRANSFER FLUSH SYSTEM

Test Engineer: Beraiy Show

5.47 PROGRAM a temperature of $375 \%$ F on the Automated Temperature Calibrator.

5.48 VERIFY the following:

$$
2 \text { per ECM wOS8-340 E,A }
$$

5.48.1 Circulation Heater \# sheath temperature high alarm TAH 302C-18 annunciates at the MCS.

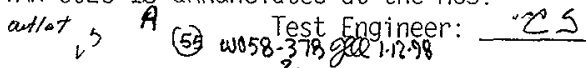

5.48.2 Circulation Heater \#x DEENERGIZES.

\section{2}

Test Engineer: CI

5.49 PLACE Circulation Heater $\# y$ control switch in the OFF position.

Test Engineer

5.50 DISCONNECT the Automated Temperature Calibrator from terminals TC5 and $T C 6$.

$$
\text { CS }
$$

5.51 RE-CONNECT the type J Process High Limit Thermocouple, TE302C-4C, to terminals TC5(Red wire) and TC6 (White wire). CS

\section{2}

5.52 PLACE Circulation Heater $\# \chi$ control switch in the ON position.

5.53 VERIFY the following:

5.53.1 Circulation Heater 2 ourler g201.22.98

clears at the MCS. CS

5.53.2 Circulation Heater \#Z ENERGIZES.

Test Engineer: CS

5. 5 PLACE Circulation Heater $\$ y^{2}$ control switch in the OFF position.

5.55 ALLOW Circulatidr Heater $\# x^{2}$ to operate long enough to cycle on and b) off via temperature controller TIC-302C-4A.

5. 66 PLACE Circulation Heatex $\# x^{2}$ control switch in the OfF position.

(56) w058-378 9201.12.98

HEATER \#7 1 per ECD WOS8 -340

E.P 
PREOPERATIONAL TEST POTP-001, CROSS SITE TRANSFER FLUSH SYSTEM

HNF. 1552

PAGE 19 OF 30

Revision No. : 0

ATTACHMENT A

1 per ECN WO5\&-34O E.P

5.57 ADJUST Circulation Heater \#2 Process Temperature Controller to approximately $10^{\circ} \mathrm{F}$ below the lowest temperature recorded in Step 5.4 above.

1 es

5.58 VERIFY Circulation Heater \#2 local control switch is in the OFF position.

Test Engineer:

1

5.59 CLOSE Circulation Heater $\# \mathcal{Z}$ local disconnect switch located next to the heater control panel.

5.59 .1 Reset Alarms (57) w058-378 112.98

5.60 RECORD the following data:

5.59 .2 Tum on heater control circuit (58) wo58-378 $2001.12 \%$

5.60.1 Recirc line water temp. (from MCS) TI-302C-2 $100^{\circ}{ }^{\circ}$.

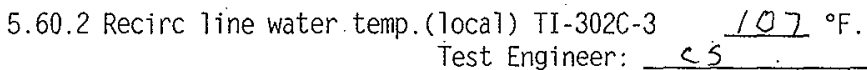

\section{1}

5.61 PLACE Circulation Heater \#2 control switch in the ON position. CS 1

5.62 VERIFY Circulation Heater \#2 DOES NOT ENERGIZE by observing that the starter contor forculat Heater $\# 2$ does not close

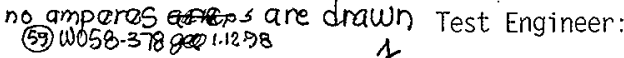
1 $\leq s$

5.63 AD.JUST Circulation Heater \#2 Process Temperature Controller to approximately $10^{\circ} \mathrm{F}$ above the lowest temperature recorded in Step above.

5.64 VERIFY Circulation Heater \#2 ENERGIZES by observing amperes ane drawn cs entator for Circulation Heater \#z closing. (6) wo58-378 200 1.12 .98 Test Engineer:

c.s 5. 55. SIMULATE a low inlet flow condition in Circulation Heater \#2 by
lifting the P16 lead at the flow switch terminal block.

5. 66 VERIFY Circulation Heater \#2 DEENERGIZES by observing the starter contactor for Circulation Heater \#L্opening. \begin{tabular}{l} 
Test Engineer: \\
(6) wo58.378 ged 1.12 .98 \\
\hline 1
\end{tabular}
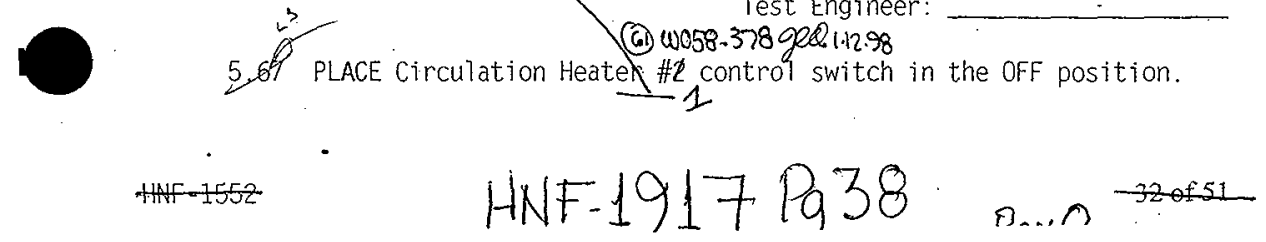
PREOPERATIONAL TEST POTP-001, CROSS SITE TRANSFER FLUSH SYSTEM

Revision No. $\underline{0}$

L5.68 RECONNEXT the P16 lead.

(6) wo58-378.2021.12.98 Test Engineer:

5 , 89 PLACE Circulation Heater \#2 control switch in the ON position.

1 per ECN wOS8-340 E.P

5.70 RE-SET the Circulation Heater \#声 Process Temperature Controller to $140^{\circ} \mathrm{F}$. CS

5.71 VERIFY Circulation Heater \#2 ENERGIZES by observing amperas aredrawn

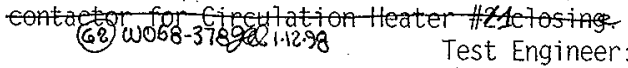

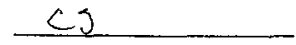

Testing Process High Temperature Limit Thermocouple

5.72 SET the process high limit controtler to $180^{\circ} \mathrm{F}$.

Test Engineer:

CS

5.73 PLACE Circulation Heater \#2 control switch in the OFF position. $\mathrm{C}$

5.74 DISCONNECT the type J Process High Limit Thermocouple, TE302C-4D, from terminals TC3(Red wire) and TC4 (White wire).

5.75 CONNECT the Automated Temperature Calibrator to terminals TC3 and TC4.

5.76 PROGRAM the thermocouple input instrument for a type $\mathrm{J} \cdots \mathrm{C}$ thermocouple.

5.77 PLACE Circulation Heater $\# 2$ control switch in the ON position. CS

5.78 VERIFY Circulation Heater \#2. ENERGIZES by observing omperesaredrown for firethation Heater \#z-efosinge ampos cs(63) wos8-3789091.1298 Test Engineer: ¿cs

5.79 PROGRAM a temperature of $180^{\circ} \mathrm{F}$ on the Automated Temperature Calibrator. CS

5.80 VERIFY the following:

5.80.1 Circulation Heater $\frac{1}{\# 2}$ outlet temperature high alarm 
PREOPERATIONAL TEST POTP-001, CROSS SITE TRANSFER FLUSH SYSTEM

Revision No. 0

HNF - 1552

ATTACHMENT A

PAGE 21 OF 30

\section{B.}

TAH-302C-1A annunciates at the MCS. Test

Engineer cs

5.80.2 Circulation Heater \#2 DEENERGIZES.

1 per ECW wors-340 ED

Test Engineer:

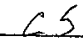

5.81 PLACE Circulation Heater $\$ 2$ control switch in the OFF position. es

5.82 DISCONNECT the Automated. Temperature Calibrator from terminals TC3 and TC4. CS $^{5}$

5.83 RE-CONNECT the type J Process High Limit Thermocouple. TE302C-4D. to terminals TC3(Red wire) and TC4 (White wire). 2S

5.84 PLACE Circulation Heater $\frac{1}{\# \mathbb{Z}}$ control switch in the ON position:

5.85 VERIFY the following:

5.85.1 Circulation Heater \#2 outlet temperature high alarm TAH-302C-1A clears at the MCS.
(65) $C$ w058 Test Engineer:
CS

5.85.2 Circulation Heater \#1 ENERGIZES:

Test Engineer:

5.86 PLACE Circulation Heater \# control switch in the OFF position. CS

Testing Sheath High Tempeature Limit Thermocouple

5.87 DISCONNECT the type J Sheath High Limit Thermocouple, TE302C-4?, $F$ from terminals TC5(Red Wire) and TC6(White Wire). CS

5.88 CONNECT the Automated Temperature Calibrator to termina TS TC5 and TC6. C.S

5.89 VERIFY the sheath high limit controller is set at $375^{\circ} \mathrm{F}$. Test Engineer: Cs

5.90 PROGRAM the thermocouple input instrument for a type $\mathrm{J}$ thermocouple. cs 
PREOPERATIONAL TEST POTP-001, CROSS SITE TRANSFER FLUSH SYSTEM

Revision No. $\underline{0}$

HNF -1552

PAGE 22 OF 30

ATTACHMENT A

5.9.1 PLACE Circulation Heater \#2 control switch in the ON position. CS

5.92 VERIFY Circulation Heater \#2 ENERGIZES by observing ampenes aredrawn contactor for Circulation Heater \#t Closing. (66) w058-378g20 1.1298 Test Engineer:

cs

5.93 PROGRAM a temperature of $375 \%^{\circ} \mathrm{F}$ on the Automated Temperature Calibrator. cS

5.94 VERIFY the following:

$5.94 .1 \quad$ Circulation Heater 12 OuTLE gOP

5.94.1 Circulation Heater \#2 sth temperature high alarm TAH-302C-1A annunciates at the MCS.

$$
\text { B } 5 \text { (60) wo58.378 Engineer: CS }
$$

5.94.2 Circulation Heater \#施 DEENERGIZES.

Test Engineer: CS

1

5.95 PLACE Circulation Heater \#2 control switch in the OFF position.es

5.96 DISCONNECT the Automated Temperature Calibrator from terminals TC5 and TC6. CS

5.97 RE-CONNECT the type J Process High Limit Thermocouple, TE302C-4D. to terminais TC5(Red wire) and TCG (White wire). CS

\section{1}

5.98 PLACE Circulation Heater \#2 control switch in the ON position.

5.99 VERIFY the following:

5.99 .1 Circulation Heater Ho 1 outer 901.2298

5.99.1 Circulation Heater \#2 sheath temperature high alarm TAH-302C-1X clears at the MCS.

$\therefore=$

$$
\begin{aligned}
& \text { B Test Engineer: CS }
\end{aligned}
$$

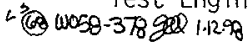

5.99.2 Circulation Heater \#2 ENERGIZES.

5. T00 PLACE Circutation Heater \#2 controt switeh-in the OfF positione

(6) $4058-378-9204278$

Test Engineer: 
PREOPERATIONAL TEST POTP-001, CROSS SITE TRANSFER FLUSH SYSTEM

Revision No. 0

HNF- 1552

PAGE 23 OF 30

ATTACHMENT A

5.101 RECORD the following data:

5.101.1 Recirc line water temp. (from MCS) TI-302C-2 $109{ }^{\circ} \mathrm{F}$.

5.101.2 Recirc line water temp. (local) $302 \mathrm{C}-32$ 102 ${ }^{\circ} \mathrm{F}$. TI-302C-3

Test Engineer: Cs

(90) $w 058-378-9201 \cdot 1298$

2001.22 .98

5.102 Check water flow on FE/FT 302C-1, adjust to $140+/-10$ gpm.

Gpm 139

Test engineer: 25

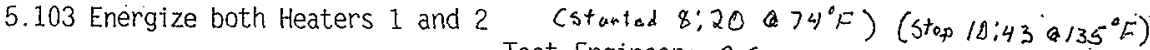

Test Engineer: CS

5.104 Operate heaters until water reaches $140^{\circ} \mathrm{F} . \pm 10 \mathrm{cs}$ (11) wo58.378 $90 Q_{1.1298}$

on Tamp Water Tank TE CS $_{12} 11102 \mathrm{C}-2$ Test Engineer: CF 12111

5.105 Verify operation of temperature controller observing contactors and for 30 minutes.

Test Engineer Cunaig Shawe 12/11

5.106 De-Energize Heaters 1 and 2

Test Engineer Cuan 5Luw 12/m

6.107. Af7ow pump P-3100A to rum for 10 mutes after heaters are-deenergized

$$
\text { CS } 12111
$$

(12) 1058.3782201 .1298

Iest Engineer

5.108 Turn Off pump P-3100A

Test Engineer CS 12/11

6.0 Water Flush Tank Sump Pump Testing

This test is a simple demonstration that the sump pump operates. TS $12 / 11$

(73) $\omega 058.3782221,1298$

Sum Pump P-302C-3 transfers waterios if $/ 11$.

6.1 VERIFY the fith Tank Sump is etere of debris that could configuration. eause fouting of the pump-suction.

Qusig Shaw $12-22-97$

-6.2-AOD water, if necssary to the Hater Flush-Fank Sump until Sump C $512 / 11$

(14) $0058-378-9821.12 .98$ 
PREOPERATIONAL TEST POTP-001, CROSS SITE TRANSFER FLUSH SYSTEM

HNF - 1552

Revision No: 0

ATTACHMENT A

PAGE 24 OF 30

Pump P-302C-3 suction 7 ine is covered by 4 to 6 inches of water.

6.3 QPEN the Sump Pump P-302C-3 discharge valve to the water Flush

Tank.

C.4 Close the power supply breaker to Sump Pump P-302C-3.

CSPS START Sump Pump P-302C-3 with local control switch.

136.6. MEASURE amps and volts

(74) 1058.378

921.12 .98

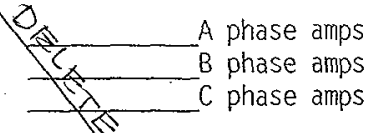

volts $A-B$

volts $A-C$

volts $B-C$

Test Engineer:

CS VERIFY Sump Pump P-302C-3 transfers water from the water Flush Tank Sump to the Water Flush Tank.

6.8. STOP Sump Pump P-302C-3 with the local dentrol switch when the sump pump loses suction.

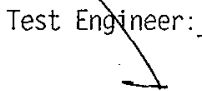

est Engineer: 
PREOPERATIONAL TEST POTP-001, CROSS SITE TRANSFER FLUSH SYSTEM

HNF -1552

PAGE 25 OF 30

Revision No. 0

ATTACHMENT A

APPENDIX A - Instrumentation Requiring Calibration Verification

\begin{tabular}{|c|c|c|c|c|}
\hline $\begin{array}{l}\text { Equipment } \\
\text { Number promp }\end{array}$ & $\begin{array}{l}\text { Functional Description } \\
05 \\
\left.c^{9}, A^{-9}\right]\end{array}$ & $\begin{array}{l}\text { Calibration } \\
\text { Date and Number }\end{array}$ & $\begin{array}{l}\text { Due } \\
\text { Date }\end{array}$ & $\begin{array}{l}\text { Sig. } \\
\text { Dates }\end{array}$ \\
\hline LIT-302C-1 Not $\begin{array}{c}\mathrm{No} \\
\mathrm{Rag}\end{array}$ & Water Flush Tank level indicatingtransmitter & $D A$ & & \\
\hline $\mathrm{TE}-302 \mathrm{C}-1 \quad 00$ & Water Flush Tank temperature element & $N A$ & & \\
\hline P. $-302 C-1$ & Flush Pump discharge pressure indicator & $\begin{array}{l}799-31-204-035 \\
5-21-97\end{array}$ & $(5-2)-5)$ & \\
\hline FT-302C-1 & Water Flush System flow transmitter. & $\begin{array}{c}\text { Caseade Anto } 17-14-27 \\
0-142 \mathrm{ggm}\end{array}$ & & \\
\hline$T E-302 C-4 A$ & Circulation Heater \#12outlet temperature element & $\begin{array}{l}11-18-47 \\
4 a / 1297-120\end{array}$ & $11-18-8$ & Gangin \\
\hline TIC-302C-4A & $\begin{array}{l}\text { Circulation Heater } \# x^{2} \text { outlet temperature } \\
\text { indicating controller }\end{array}$ & $\begin{array}{l}97102 \mathrm{Cm} . \\
8-29-97\end{array}$ & $8-27-x 8$ & $\angle s$ \\
\hline FSL $-302 C-4 A$ & Circulation Heater $\# x^{2}{ }_{\text {inlet low flow switch }}$ & N/A FUNGTONAL \&TEOOOS & $2,-5.6$ & \\
\hline TE-302C-48 & Circulation Heater $\# 2^{1^{*}}$ out let temperature element & $\begin{array}{l}11-18-47 \\
6,1+27-119 \\
\end{array}$ & & \\
\hline $\begin{array}{l}302 C-48 \\
T / C\end{array}$ & $\begin{array}{l}\text { Circulation Heater } \$ 21 \text { outlet temperature }^{*} \\
\text { indicating controller }\end{array}$ & $\begin{array}{l}9-29-97 \\
97-98\end{array}$ & $3-24-98$ & \\
\hline FSL-302C-4B & Circulation Heater \#23 inlet low flow switch & NA FUNCTROWALTE & 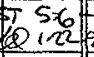 & 98.8 \\
\hline$T E-302 C-3\}$ Conth & $\begin{array}{l}\text { Water Flush Tank recirc header temperature } \\
\text { element }\end{array}$ & $\begin{array}{l}1-18-97 \\
(a)+97-121\end{array}$ & $1.88-3$ & $\operatorname{cs}$ \\
\hline TI $-302 C-3$ & $\begin{array}{l}\text { Water Flush Tank recirc header temperature } \\
\text { indicator }\end{array}$ & $\begin{array}{l}11+18+97 \\
621 \neq 97-121\end{array}$ & $11-898$ & $\angle 3$ \\
\hline$T E-302 C-2$ & $\begin{array}{l}\text { Water Flush Tank recirc header temperature } \\
\text { element }\end{array}$ & $\begin{array}{l}11-18-47 \\
\text { col } 47118\end{array}$ & $1 \ln 8.80$ & Cunety \\
\hline$\equiv P I-302 C-2$ & $\begin{array}{l}\text { Water Flush Tank recirc header pressure } \\
\text { indicator }\end{array}$ & $\begin{array}{l}399-31.04-036 \\
5-27-97\end{array}$ & $5-23-98$ & $\operatorname{cin} 3$ \\
\hline $\mathrm{PI}-302 \mathrm{C}-3$ & $\begin{array}{l}\text { Chemical Addition Pump discharge pulsation } \\
\text { dampener pressure indicator }\end{array}$ & $9-24-9.7$ & & 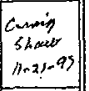 \\
\hline$P I-302 C-4$ & $\begin{array}{l}\text { Chemjcal Addition Pump discharge pressure } \\
\text { indicator }\end{array}$ & $9-24-97$ & 1 & 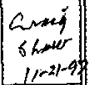 \\
\hline $\mathrm{FE} / \mathrm{FT}-302 \mathrm{C}-2$ & Water Flush Tank fill line flow transmitter & 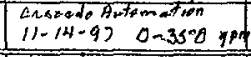 & $11-14-9$ & Condent \\
\hline $302 \mathrm{C}-3$ & Chem Injec. Backpressure valve & FELBST PER का & P 1.5 & \\
\hline
\end{tabular}

* per ECN N058-340 See fach of Page

EP

HNF-1552

HNF-1917 Pa 44 Revo

38 of 51 


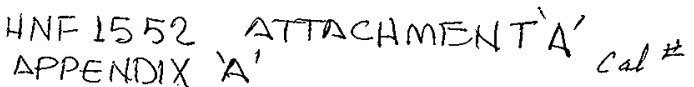

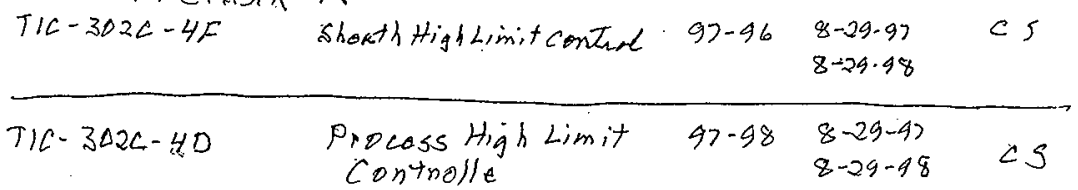

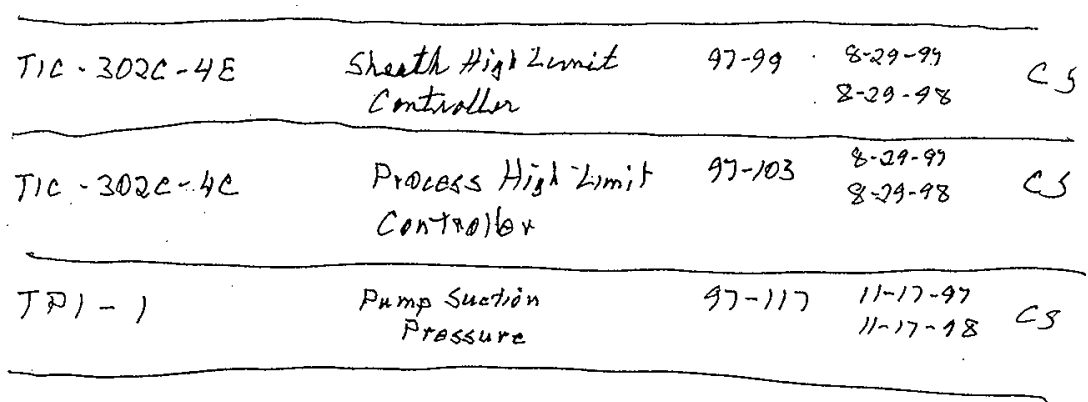

added per (27) w-058.378 $\mathrm{gell}_{1 / 1298}$

HNF-1917 P 945 Revo 
PREOPERATIONAL TEST POTP-001, CROSS SITE TRANSFER FLUSH SYSTEM

HNF- 1552

Revision No. 0

ATTACHMENT A

PAGE 26 OF 30

\begin{tabular}{|c|c|c|c|c|}
\hline \multicolumn{4}{|c|}{ APPENDIX A - Instrumentation Requiring Calibration Verification } & \\
\hline $\begin{array}{l}\text { Equipment } \\
\text { Number }\end{array}$ & Functional Description & $\begin{array}{l}\text { Calibration } \\
\text { Date and Number }\end{array}$ & $\begin{array}{l}\text { Due } \\
\text { Date }\end{array}$ & $\begin{array}{l}\text { Sig. } \\
\text { Date }\end{array}$ \\
\hline PRV $-302 C-1$ & Heater relief & Lead sealad & & 45 \\
\hline PRV $-302 C-2$ & Heater Relief & Lend Sanled & & cs \\
\hline
\end{tabular}

\begin{tabular}{|c|c|c|c|c|}
\hline \multicolumn{4}{|c|}{ APPENDIX B -Cross Site Transfer Flush System Valve Initial Alignment } & \multirow[b]{2}{*}{$12 / 8$} \\
\hline $\begin{array}{c}\text { VALVE } \\
\text { NUMBER } \\
\end{array}$ & VALVE NAME & $\begin{array}{l}\text { REQUIRED } \\
\text { POSITION }\end{array}$ & INITIALS & \\
\hline 2" drain valve & Water Flush Tank drain valve & CLOSED & cs & 2 \\
\hline$V-3188 \mathrm{~A}$ & Flush Pump suction valve & CLOSED & CS & 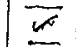 \\
\hline V. $3188 B$ & Flush Pump discharge line drain valve & CLOSED & $c s$ & $=$ \\
\hline$V-3188 \mathrm{C}$ & Circulation Heater \# $I^{2}$ bypass valve & OPEN & $c s$ & $\approx$ \\
\hline$V-31880$ & Circulation Heater \#2 '́nypass vaive & OPEN & $<s$ & $\simeq$ \\
\hline V-3188E & Circulation Heater $\# \boldsymbol{l}$ out let valve & CLOSED & CS & $\widetilde{r}$ \\
\hline V. $3188 \mathrm{~F}$ & Circulation Heater $\# Z$ innjet valve & CLOSED & $\angle s$ & $\nabla$ \\
\hline V-3188G & Circulation Heater \#zloutlet valve & CLOSED & cs & $\bar{\tau}$ \\
\hline $\mathrm{V}-3188 \mathrm{H}$ & Circulation Heater \#z liñlet valve & CLOSED & cs & 2 \\
\hline$V-3187 \mathrm{~A}$ & $\begin{array}{l}\text { Flush System recirc header isolation to } \\
\text { Water Flush Tank. }\end{array}$ & $\begin{array}{l}\text { CLOSED \& } \\
\text { LOCKED }\end{array}$ & cs & $\sim$ \\
\hline$V \cdot 3187 \mathrm{~B}$ & $\begin{array}{l}\text { Flush System recirc header isolation valve } \\
\text { to transfer headers }\end{array}$ & CLOSED & cs & $\checkmark$ \\
\hline$V-31876 \frac{11.27}{O^{R}(c)}$ & 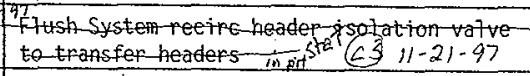 & CLOSED & $c 5$ & \\
\hline SW-V. 3130 & $\begin{array}{l}\text { Service water isolation to transfer } \\
\text { headers, (28) w958-378200/h2tis }\end{array}$ & CLOSED & CS & \\
\hline SW-V-311595 @i-221 & osservice water main isolation valve & OPEN & CS & \\
\hline$S W-V-3131$ & $\begin{array}{l}\text { Flush water Tank fi1] ine flow } \\
\text { transmitter FE/FT-302C-2 inlet isolation } \\
\text { valve }\end{array}$ & OPEN & $\operatorname{cs}$ & $\checkmark$ \\
\hline$V-3186 C$ & Flush Water Tank fill line drain valve & CLOSED & 65 & $\sqrt{ }$ \\
\hline V-3186B & $\begin{array}{l}\text { Flush water Tank fill line flow } \\
\text { transmitter } \mathrm{FE} / \mathrm{FT}-302 \mathrm{C}-2 \text { outlet isolation } \\
\text { valve }\end{array}$ & OPEN. & CS. & \\
\hline $\mathrm{V}-3186 \mathrm{~A}$ & Flush Water Tank fill line isolation valve & CLOSED & 05 & $\underline{E}$ \\
\hline $\begin{array}{l}\text { Swav-3198 } \\
\text { * per ECM } \\
\text { HAF- } 1552\end{array}$ & $\begin{array}{l}\text { SW Pressara gajo isoletion valua } \\
\text { wo58-340 EP }\end{array}$ & open & CS & \\
\hline
\end{tabular}


PREOPERATIONAL TEST POTP-001, CROSS SITE TRANSFER FLUSH SYSTEM

Revision No. 0

HNF -1552

ATTACHMENT A

PAGE 27 OF 30

\begin{tabular}{|c|c|c|c|}
\hline \multicolumn{4}{|c|}{$\begin{array}{l}\text { APPENDIX } \dot{B} \text {-Cross Site Transfer Flush System Valve Initial Alignment } \\
\text { VAI VF }\end{array}$} \\
\hline $\begin{array}{l}\text { VALVE } \\
\text { NUMBER } \quad 11-2 \\
\end{array}$ & 10 & $\begin{array}{l}\text { REQUIRED } \\
\text { POSITION }\end{array}$ & INITIALS \\
\hline $\begin{array}{r}V-302 C-1704 \\
\text { Removed for Tos }\end{array}$ & $\begin{array}{l}\text { Chemica? Addition Systém injection line } \\
\text { vent valve }\end{array}$ & $\begin{array}{l}\text { OPEN } \\
\text { Removod }\end{array}$ & $N A$ \\
\hline$V \cdot 302 C-3$ & $\begin{array}{l}\text { Chemical Addition System injection line } \\
\text { drain valve }\end{array}$ & CLOSED & ¿s \\
\hline$V-302 C-5$ & $\begin{array}{l}\text { Chemical Addition Pump discharge line } \\
\text { drain valve. }\end{array}$ & CLOSEO & $<S$ \\
\hline$V \cdot 302 C \cdot 4$ & $\begin{array}{l}\text { Chemical Addition Pump discharge pressure } \\
\text { gauge PI }-302 \mathrm{C}-4 \text { isolation valve }\end{array}$ & OPEN & es \\
\hline TV -1 & Temporary Flush Pump Suction Valve & CLOSED & $<s$ \\
\hline TV-2 & Temporary Tank fill/Recirc. Valve & CLOSED & $C S$ \\
\hline TV.3 & Temporary Block valve & Closed & cs \\
\hline TV -4 & Temporary Vent Valve for Chem Add. & Closed & 69 \\
\hline$T V-5$ & Tamp Block ualve for cham Pump (S) $x$ h & closed & $c s$ \\
\hline$V-302 C-4$ & $\begin{array}{l}\text { Chemical Addition Pump discharge pressure } \\
\text { gauge PI-302C-4 isolation valve }\end{array}$ & OPEN & 6.5 \\
\hline
\end{tabular}

A vishau, Verified
PRINT NAME
$\frac{C S}{\text { TIALS }}-\frac{11.24-4 Z^{B Y}}{\text { DATE }}$
$\frac{\text { Reictmongt }}{\text { PRINT NAME }}$
$\frac{Q P 2}{\text { INITIALS }}$
1 per ECO WOS8-340 EP
U $302<-2$
Heater $z$ Drain value
No Tag
Heater ${ }_{2}$ Drain $V_{a} l_{0}$
closed
CS
closed
$<5$
$v-322 c-8$
Cham Supply $V_{a}$ ) ve
$\Delta$ pon
cs
$\$ 540-v-3196$ Water Supply
open

$\frac{11-24-97}{D A T E}$

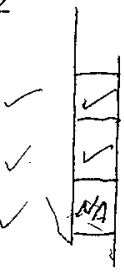


PREOPERATIONAL TEST POTP-001, CROSS SITE TRANSFER FLUSH SYSTEM

HNF - 1552

Revision No. 0

ATTACHMENT A

PAGE 26 OF 30

APPENDIX A - Instrumentation Requiring Calibration Verification

\begin{tabular}{|c|c|c|c|c|}
\hline $\begin{array}{l}\text { jipment } \\
\text { mber } \\
J-302 C-1\end{array}$ & $\begin{array}{l}\text { Functional Description } \\
\text { Heater relief }\end{array}$ & $\begin{array}{l}\text { Calibration } \\
\text { Date and Number } \\
\text { see page } 46\end{array}$ & $\begin{array}{l}\text { Due } \\
\text { Date }\end{array}$ & $\begin{array}{l}\text { Sig. } \\
\text { Oate }\end{array}$ \\
\hline & & see-page 46 & & \\
\hline$d-302 C-2$ & Heater Relief & & & \\
\hline
\end{tabular}

APPENDIX B - Cross Site Transfer Flush System Valve Initial Alignment

\begin{tabular}{|c|c|c|c|c|c|}
\hline $\begin{array}{l}\text { VALVE } \\
\text { NUMBER } \\
\end{array}$ & VALVE NAME & $\begin{array}{l}\text { REQUIRED } \\
\text { POSITION } \\
\end{array}$ & $\begin{array}{l}\text { INITIALS } \\
12 / 9 / 47 \\
\end{array}$ & $12 / 10 / 27$ & $12 / 11 / 27$ \\
\hline 2" drain valve & Water Flush Tank drain valve & CLOSEO & $N A$ & $N A$ & $N A$ \\
\hline$V-3188 \mathrm{~A}$ & Flush Pump suction valve & CLOSED & $N A$ & $N A$ & $N A$ \\
\hline V.3188B & Flush Pump discharge line drain valve & CLOSED & CS & $c 5$ & $c s$ \\
\hline V.3188C & Circulation Heater $\# x^{2}$ bypass valve & OPEN & as & $<5$ & cS. \\
\hline$V-31880$ & Circulation Heater $\mathbb{Z} 2$ bypass valve & OPEN & CS & CS & $c s$ \\
\hline$V-3188 E$ & Circulation Heater $\# l^{2}$ outlet valve & CLOSED & Cs & $<s$ & $\mathrm{Cs}^{2}$ \\
\hline V.3188F & Circulation Heater $\# x^{2}$ inlet valve & CLOSED & Cs & $\operatorname{cs}$ & cs \\
\hline$V-3188 G$ & Circulation Heater Hz outlet valve & CLOSED & es & cs & es \\
\hline V.3188H & Circulation Heater $\#$ ? Inlet valve & CLOSED & $C S$ & 45 & $\leqslant s$ \\
\hline$V \cdot 3187 \mathrm{~A}$ & $\begin{array}{l}\text { Flush System recirc header isolation to } \\
\text { Water Flush Tank }\end{array}$ & $\begin{array}{l}\text { CLOSED \& } \\
\text { LOCKEO }\end{array}$ & cs & cs & $c s$ \\
\hline V-3187B & $\begin{array}{l}\text { Flush System recirc header isolation valve } \\
\text { to transfer headers }\end{array}$ & CLOSED & es & cs & $c s$ \\
\hline$V-3187 \mathrm{C}$ & $\begin{array}{l}\text { Flush System recirc header isolation valve } \\
\text { to transfer headers }\end{array}$ & CLOSED & $<s$ & $c^{5}$ & $\mathrm{CS}$ \\
\hline SW-V.3130 & $\begin{array}{l}\text { Service water isolation to transfer } \\
\text { headers. }\end{array}$ & CLOSEO & es & $<s$ & $<s$ \\
\hline$S W \cdot V-312595$ & Service water main isolation valve & OPEN & $c s$ & $c 5$ & $c s$ \\
\hline SW-V-3131 & $\begin{array}{l}\text { Flush Water Tank fill line flow } \\
\text { transmitter FE/FT-302C-2 inlet isolation } \\
\text { valve }\end{array}$ & OPEN & $c s$ & ds & $c s$ \\
\hline$V-3186 C$ & Flush water Tank fill line drain valve & CLOSED & cs & $c^{s}$ & Cs \\
\hline$V \cdot 3186 B$ & $\begin{array}{l}\text { Flush Water Tank fill line flow } \\
\text { transmitter FE/FT-302C.2 outlet isolation } \\
\text { valve }\end{array}$ & OPEN & $\operatorname{cs}$ & Cs & $C S$ \\
\hline$V \cdot 3186 \mathrm{~A}$ & Flush Water Tank fill line isolation valve & CLOSED & ES & $<s$ & $\operatorname{cs}$ \\
\hline
\end{tabular}

* per ecau wo58-340 e.s

$+4+1552$ 
PREOPERATIONAL TEST.POTP-001, CROSS SITE TRANSFER FLUSH SYSTEM

Revision No. 0 HNF - 1552

ATTACHMENT A

\begin{tabular}{|c|c|c|c|}
\hline \multicolumn{4}{|c|}{ APPENDIX C - Cross Site Transfer Flush System Electrical Aligniment } \\
\hline $\begin{array}{l}\text { BREAKER } \\
\text { NUMBER }\end{array}$ & BREAKER NAME AND LOCATION & $\begin{array}{l}\text { REQUIRED } \\
\text { POSITION }\end{array}$ & INITIALS \\
\hline $3 B$ & $\begin{array}{l}\text { FTush Tank Feeder Breaker in } \\
\text { Switchgear SWG-E-001, Bus \#2 } 1\end{array}$ & CLOSED/ON & \\
\hline $5 B$ & $\begin{array}{l}\text { Flush Tank Feeder Breaker in } \\
\text { Switchgear SWG-E-001, Bus } 2\end{array}$ & CLOSED/ON & \\
\hline$z$ & $\begin{array}{l}\text { Circulation Heater \#l local ON/OFF' } \\
\text { switch labeled "Control circuit" on } \\
\text { heater control panel }\end{array}$ & OPEN/OFF & \\
\hline$?$ & $\begin{array}{l}\text { Circulation Heater \#2 local ON/OFF } \\
\text { switch labeled "Control Circuit" } \\
\text { switch on heater control panel }\end{array}$ & OPEN/OFF & \\
\hline$?$ & $\begin{array}{l}\text { Flush Pump P-3100A local disconnect } \\
\text { on pump control panel }\end{array}$ & OPEN/OFF & \\
\hline$\not 2$ & $\begin{array}{l}\text { Panelboard PP-1 main feeder breaker } \\
\text { in PP.1 }\end{array}$ & CLOSED/ON & \\
\hline Breaker \#3 & $\begin{array}{l}\text { Panelboard PP - } 1 \text { feeder breaker to } \\
\text { the Chemical Addition Pump skid }\end{array}$ & OPEN/OFF & \\
\hline Breaker \#5 & $\begin{array}{l}\text { Panelboard PP-1 feeder breaker to } \\
\text { FE/FT-302C-1 }\end{array}$ & CLOSED $/ O N$ & \\
\hline Breaker \#7 & $\begin{array}{l}\text { Panelboard PP-1 feeder breaker to } \\
\text { FE/FT-302C-1 }\end{array}$ & CLOSED/ON & \\
\hline Breaker \#2 & $\begin{array}{l}\text { Panelboard PP-1 feeder breaker to } \\
\text { pipe heat trace }\end{array}$ & CLOSED/ON & \\
\hline Breaker \#4 & $\begin{array}{l}\text { Panelboard PP-1 feeder breaker to } \\
\text { drum heater }\end{array}$ & OPEN/OFF & \\
\hline Breaker \#6 & $\begin{array}{l}\text { Panelboard PP-I feeder breaker to } \\
\text { double pipe heat trace }\end{array}$ & CLOSED/ON & \\
\hline & & & \\
\hline & & & \\
\hline
\end{tabular}

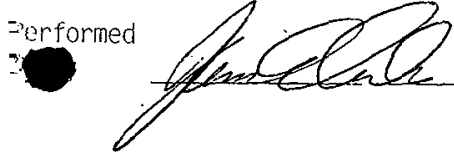

HAF- 1552
$11 / 21 / 97$ BY $^{\text {verified }}$ Plomatol 11.21 .97 HWF-1917 Pg 50 Revo 
PREOPERATIONAL TEST POTP-001, CROSS SITE TRANSFER FLUSH SYSTEM

Revision No. 0 HNF - 1552

ATTACHMENT A
PRINT NAME INITIALS DATE

APPENDIX D-1 OPERATION DATA SHEET
PRINT NAME INITIALS DATE MOTOR NAMEPGATE DATA DIEK 9804

Frame N: 256T

Sorich $\mathrm{Y}^{\circ}$ : 0.3970205839

Finsulation: crmbicnt $40^{\circ} \mathrm{C}$ EMC-T ifP 20

RPr 35.10 230/460 V

nup $471230 \cdot 29.51460 \quad 60 \mathrm{~Hz}$ CAdPC SF 1.15 DESV NEATA 90.5 NAMEPLATE DATA: AA govides puMe - IMe o $7.62=140 \mathrm{gam}$

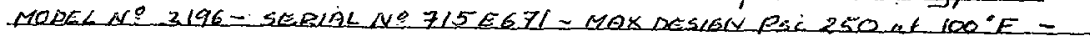
DUNY centivivers BEARRCOSS: $\angle O B C O Z \quad 45 B C O B$ $X P P X 30 X$

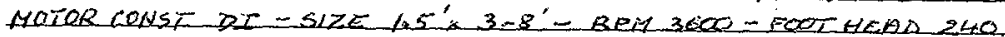
Attach four targets to the pump to establish the locations for vibration measurements. Att
target number 1 to the top of the motor end bearing housing, and target number 2 pump end Attach four targets to the pump to establish the 70 cations. for vibration measurements. Attach
target number 1 to the top of the motor end bearing housing, and target number 2 pump end bearing housing. Attach target number 3 to the discharge flange inline with the suction. Attach target number 4 on the discharge flange $90^{\circ}$ from target number 3 .

SEE EXCEPTION TIE-003

Flow to be within $+1-10 \%$

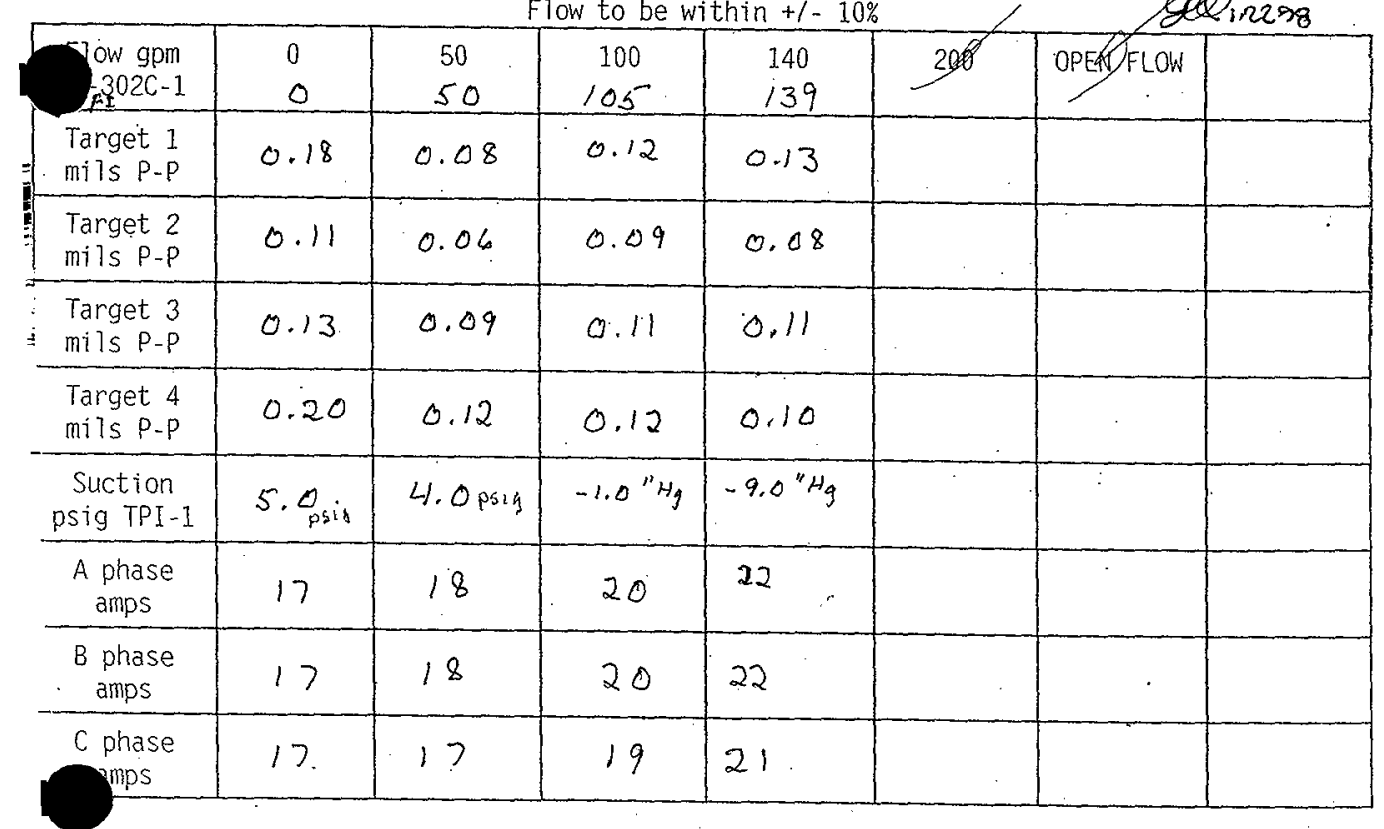

$H A F=1552$ 
PREOPERATIONAL TEST POTP-001, CROSS SITE TRANSFER FLUSH SYSTEM $\begin{array}{ll}\text { Revision No. } 0 & \text { HNF-1552 } \\ \text { ATTACHMENT A }\end{array}$

\begin{tabular}{|c|c|c|c|c|c|c|}
\hline $\begin{array}{c}\text { Voltage A- } \\
\text { B }\end{array}$ & 503 & 504 & $5 \Delta 3$ & 503 & 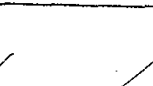 & \\
\hline $\begin{array}{r}\text { Flow gpm } \\
\text { FI-302C-1 } \\
\end{array}$ & 0 & $\begin{array}{l}50 \\
50 \\
\end{array}$ & $\begin{array}{l}100 \\
105 \\
\end{array}$ & $\begin{array}{l}150 / 40 \\
139\end{array}$ & OPEN F KOW & 140 \\
\hline $\begin{array}{c}\text { Voltage A- } \\
C\end{array}$ & 503 & 502 & 501 & 501 & & · \\
\hline $\begin{array}{c}\text { voltage B- } \\
\mathrm{C}\end{array}$ & 499 & 500 & 501 & 499 & & \\
\hline $\begin{array}{l}\text { Discharge } \\
\text { psig (PI- } \\
302 \mathrm{C}-1)\end{array}$ & 120 & 120 & 100 & 100 & & \\
\hline $\begin{array}{c}\text { Static } \\
\text { correction } \\
(\mathrm{ft})\end{array}$ & $N A$ & $N A$ & $N A$ & $N A$ & & \\
\hline
\end{tabular}

Record Bearing Housing temperature after completing last vibration measurement. at-200 gpm Temperature: 73.4 of (amb $45^{\circ} \mathrm{F}$ )

REMARKS: FLOW, STE SUCTON AND DISCHARGE PRESSURES REQUIRED TO ESTABLSH PUMP - PERFoRnADNCE UIBRDTION LESS THAN l.5 mils P-P ACCEPTABLE.

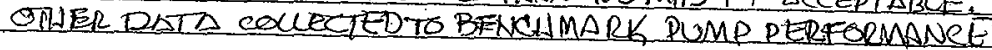
2e सियक्ष

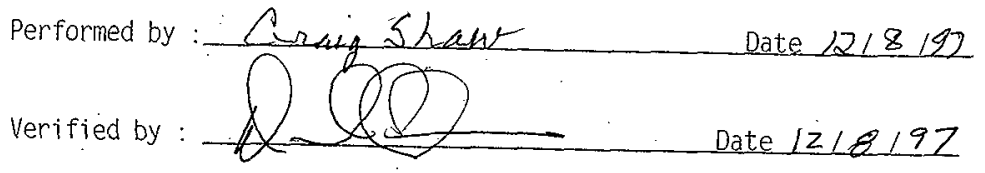




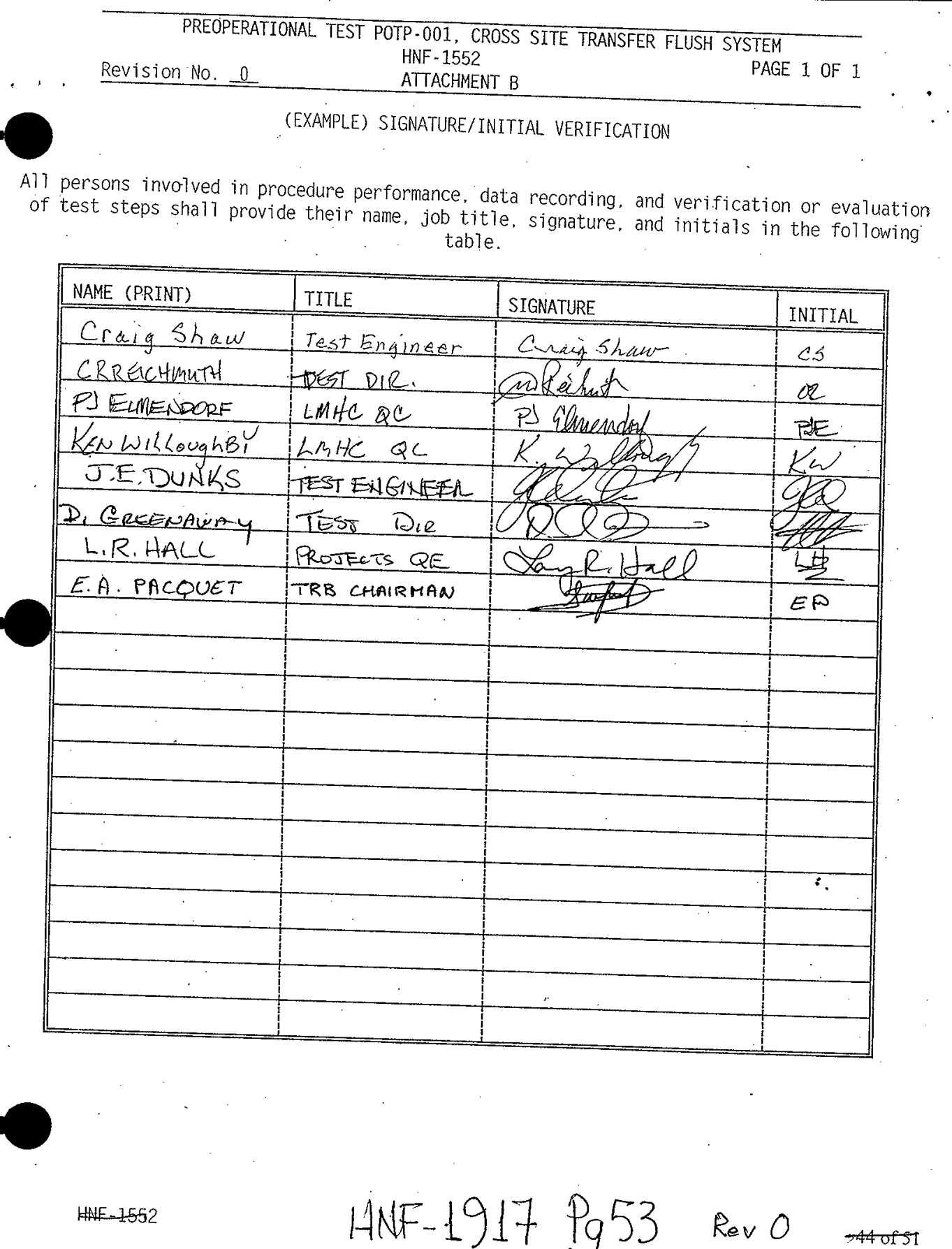


Revision No.. 0

ATTACHMENT $C$

PAGE 1 OF 1

\section{TEST LOG}

TEST TITLE:

TIME/DATE

EVENT DESCRIPTION/SIGNATURE

$(1-2)-9)$

$11-21.97$

1) $-21-97$

FE/FT $302 \mathrm{c-1}$ calib mated $0-142 \mathrm{gpm}$

$11-24-47$

(1) $-241-97$

add instrument cal dete to back of $38 / 51$ for

for $T / C-302 C-4 F, T / C-302 C-4 D$,
TDL- $T / C-302 C-4 E, T / C-302 C-4 E$

added to page $39 / 51$.

$v-3196$ Valve $s \omega-v-3 / 98$ Eisolation valua for $5 w-0 /-3 / 28$ pess, gags.

"m

$(1-24-4)$

$11-24-17$

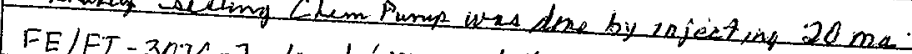

$11.24-97$

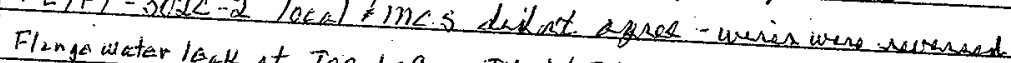

Flonge watar lakk at Tea bafere TV-LISTU-2

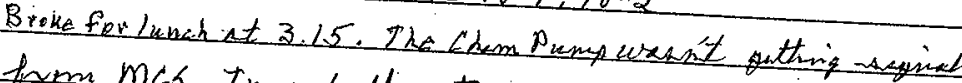

$11-24-97$ fom MCb. Twamed of whter.

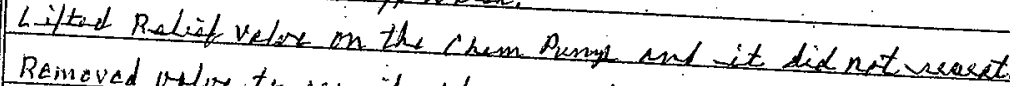

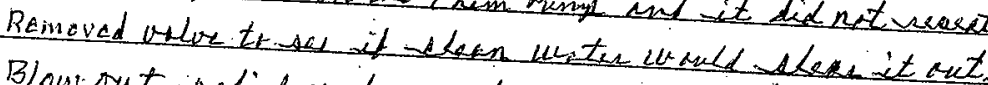

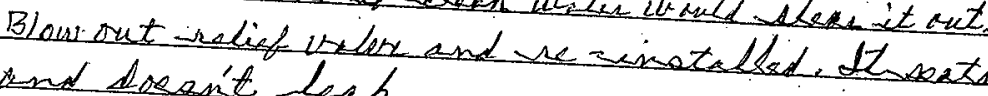
rond Losen't Leak.

$11-22 \cdot 97$ stoped $s_{A}<3,0$ - treme the

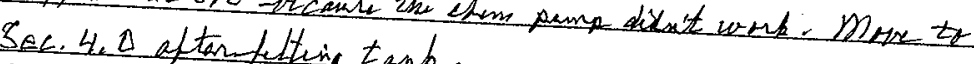

$11-25.97$ sech telting $\tanh$.

Steps $4.1 \rightarrow 4.3$ ware dome vis Soltwene 
PREOPERATIONAL TEST POTP-001, CROSS SITE TRANSFER FLUSH SYSTEM HNF-1552

Revision No. 0 ATTACHMENT $C$

TEST LOG

ST TIRE:

TIME/DATE EVENT DESCRIPTION/SIGNATURE

11-26-47 Movfind stap 4,17 to bump P3/20A and chend antation. adbl step 4.17.1 to run P3/20A to paige air fiom loop. 14.26-97 p3100A Starter Keot fripingout millimunt sated

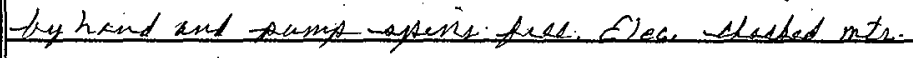

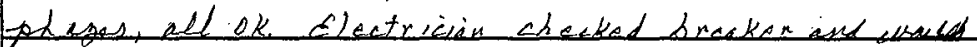

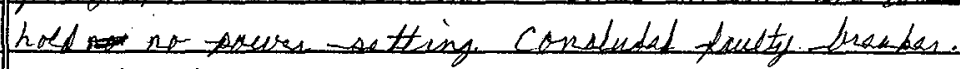
Notified van Natwik (NHE) and "Muser Mike at FonW. Gave "Dner mikh" catalog on of sreaker. 2-1-97 Redaced breaker for p3100 A. Kent tripoine. Findly determined motor was wired for low voltige. Wired for high roltage. Sot 8 raker at 300 becouse that ures

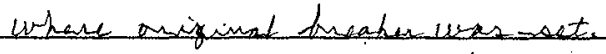

2:1-.97 Punched biole in pump dischange rubbax lidnows due to ovensized wushers. Stopoed test pending neplacmol of bellows due tounsopenditum. 
PREOPERATIONAL TEST POTP-001, CROSS SITE TRANSFER FLUSH SYSTEM

Revision No. 0 HNF - 1552

PAGE 1 OF 1 ATTACHMENT C

TEST LOG

TEST MUMER:
TEST LOG

PAGE NUMBER:

4 of 4

ST TIRE:

TIME/DATE EVENT DESCRIPTION/SIGNATURE

12-10-47 Unable to run new Chem pump teesere of nonil for operation undex $50^{\circ} \mathrm{F}$ obtained oil of correct viscosity for $<50^{\circ} \mathrm{F}$.

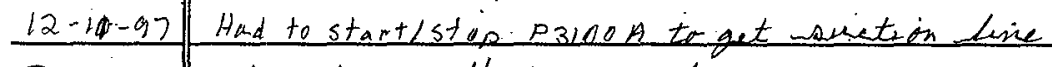
chened and all ain purach

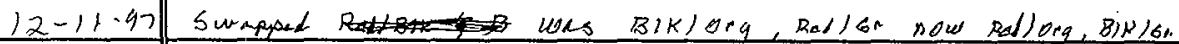
teads to cham pump centrol.

(.22.98 RE: INJECTION PUMP "MANUAL"SETTNB. THE TESTED DUMPWAS NOT CAPABLE CF

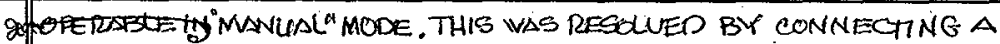
PROCESSINSTRUMENTCALRRATOR AND MANUAUUK INFUTTING THE DESIRESD SETTING, (REF, SEC? 

ATTACHMENT E

\section{TEST EXCEPTION LOG}

\begin{tabular}{|c|c|c|c|c|}
\hline TE \# & DATE & DESCRIPTION & DISPOSITIONED & DATE CLOSED \\
\hline 1 & $11+21-97$ & 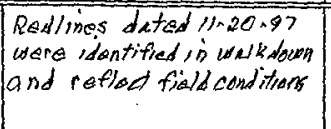 & $\begin{array}{l}\text { This is not an Exapption } \\
\text { Connet wia ESN }\end{array}$ & $N A$ \\
\hline 2. & $|1-21-9|$ & 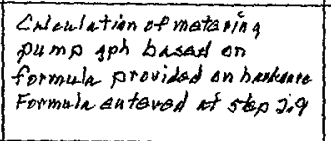 & 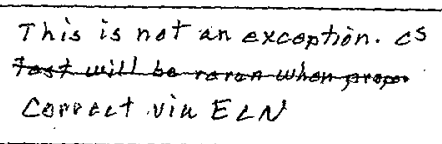 & NA \\
\hline 3 & $\mid 11-31-9)$ & $\begin{array}{l}p_{\text {hmp }} p-3 / 00 B \text { usill be } \\
\text { rad aced by proparpamp }\end{array}$ & This is not an exeeption. es & $N A$ \\
\hline 4 & $11-21-97$ & $\begin{array}{l}\text { FE/FT }-302 c-1 \text { was } \\
\text { found calid rated } 0-142 \text { grow }\end{array}$ & Yes & $12-1-97$ \\
\hline 5 & $11-26-97$ & $\begin{array}{l}\text { Bumping p3/00A, }(4.17) \\
\text { tripped breakkar }\end{array}$ & Yes & $12+2-97$ \\
\hline 6 & $\mid 2-1-47$ & $\begin{array}{l}\text { Pump dischuirge bellows } \\
\text { failed. }\end{array}$ & yes & $12-8.97$ \\
\hline 7 & $12 \cdot 8 \cdot 97$ & 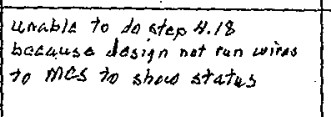 & 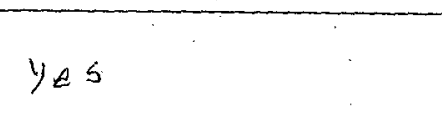 & $12-17 \cdot 97$ \\
\hline 8 & $12-8-97$ & $\begin{array}{l}\text { Step } 4.41 \text { did not } \\
\text { execute. }\end{array}$ & Yes & $12-17+47$ \\
\hline
\end{tabular}




Revision No. $0 \quad$ HNF- 2552
ATTACHMENT E. PAGE 1 OF 1

Revision No. 0 ATTACHMENT E

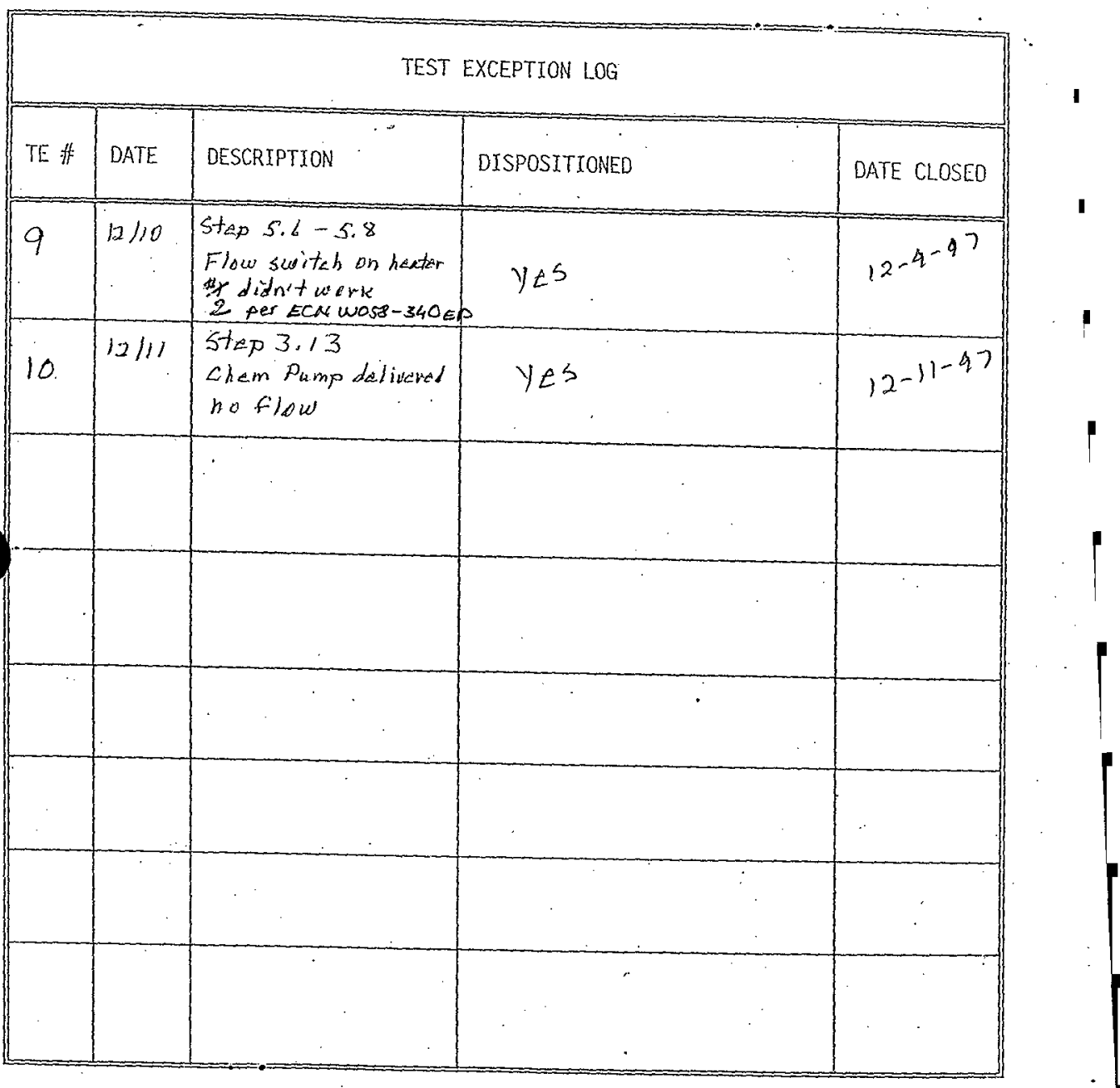


PREOPERATIONAL TEST POTP-001, CROSS SITE TRANSFER FLUSH SYSTEM INF - 1552

PAGE 1 OF 1

Revision No. 0

ATTACHMENT D

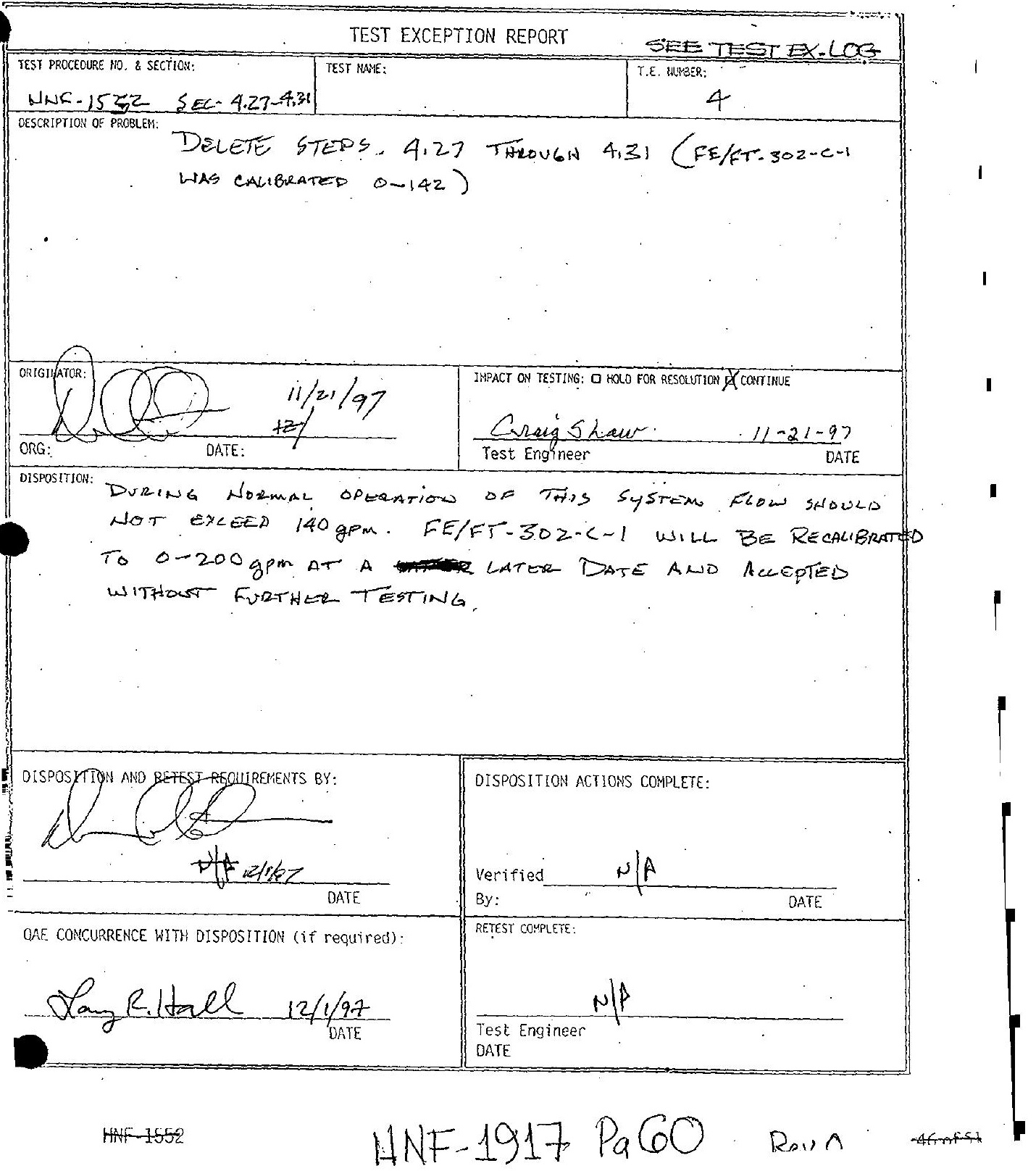




PREOPERATIONAL TEST POTP-001, CROSS SITE TRANSFER FLUSH SYSTEM
HNF-1552
ATTACHMENT D
Revision No. 0

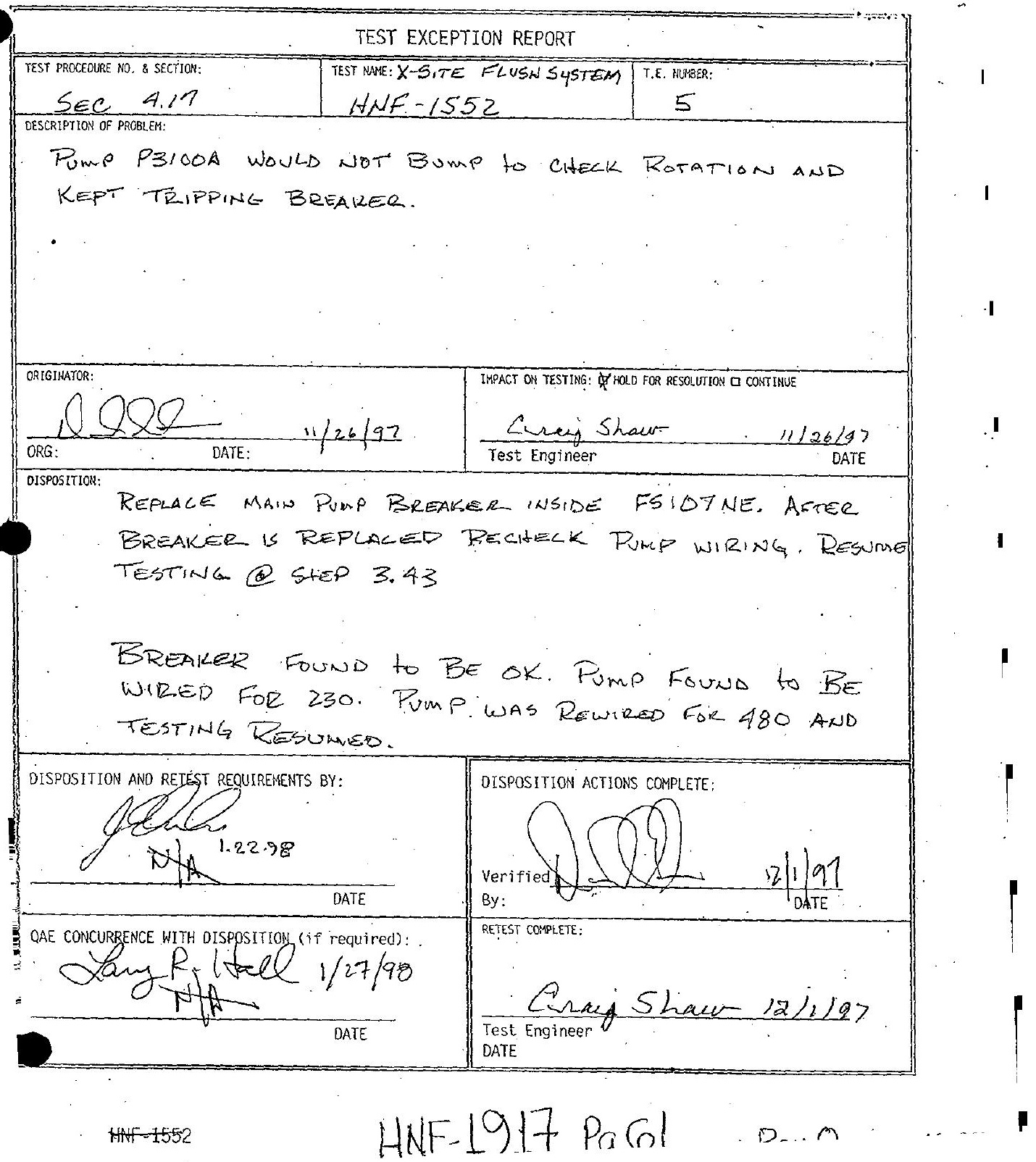




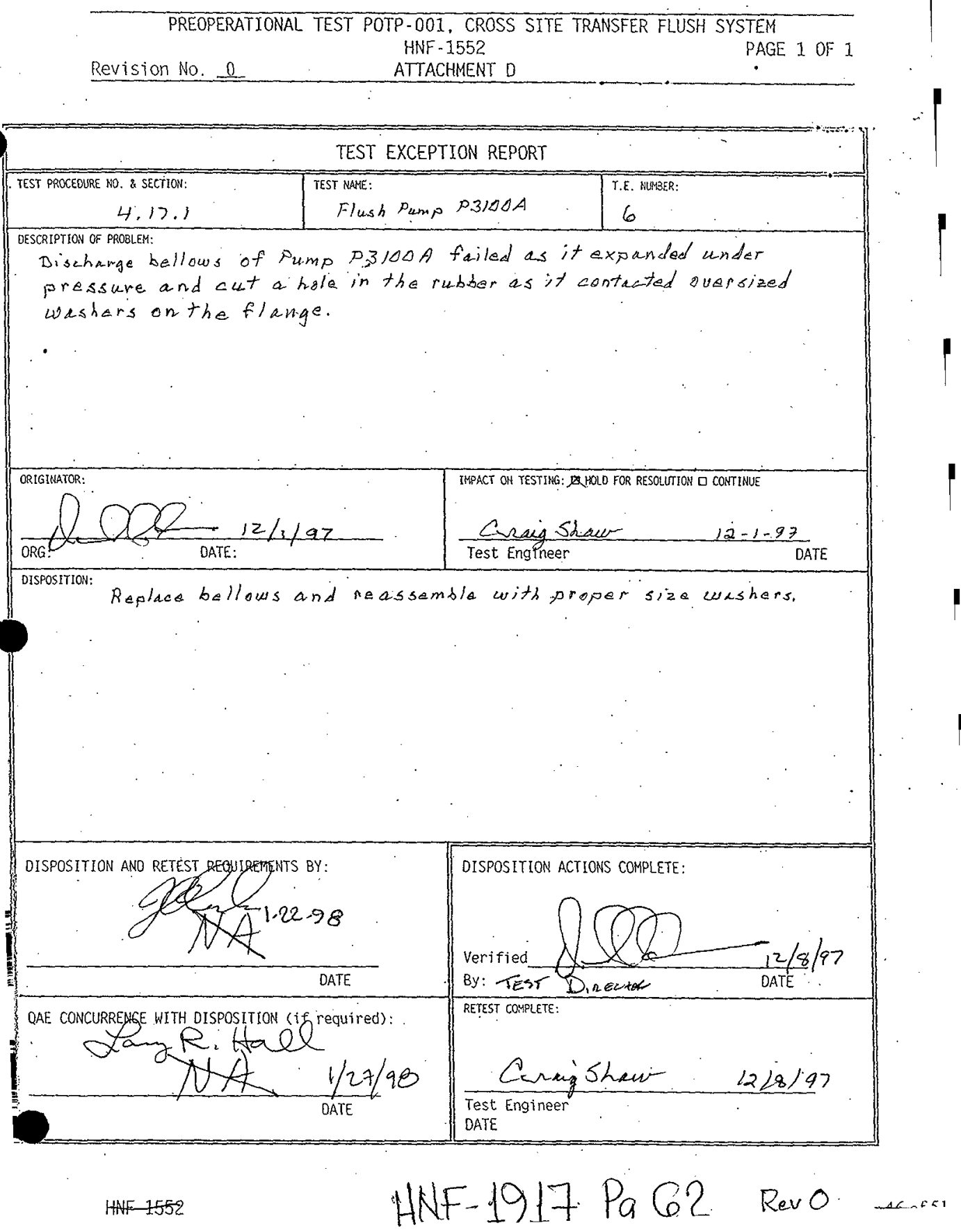




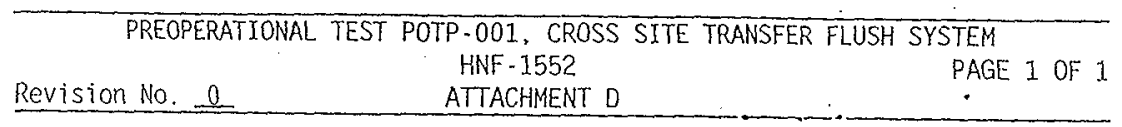

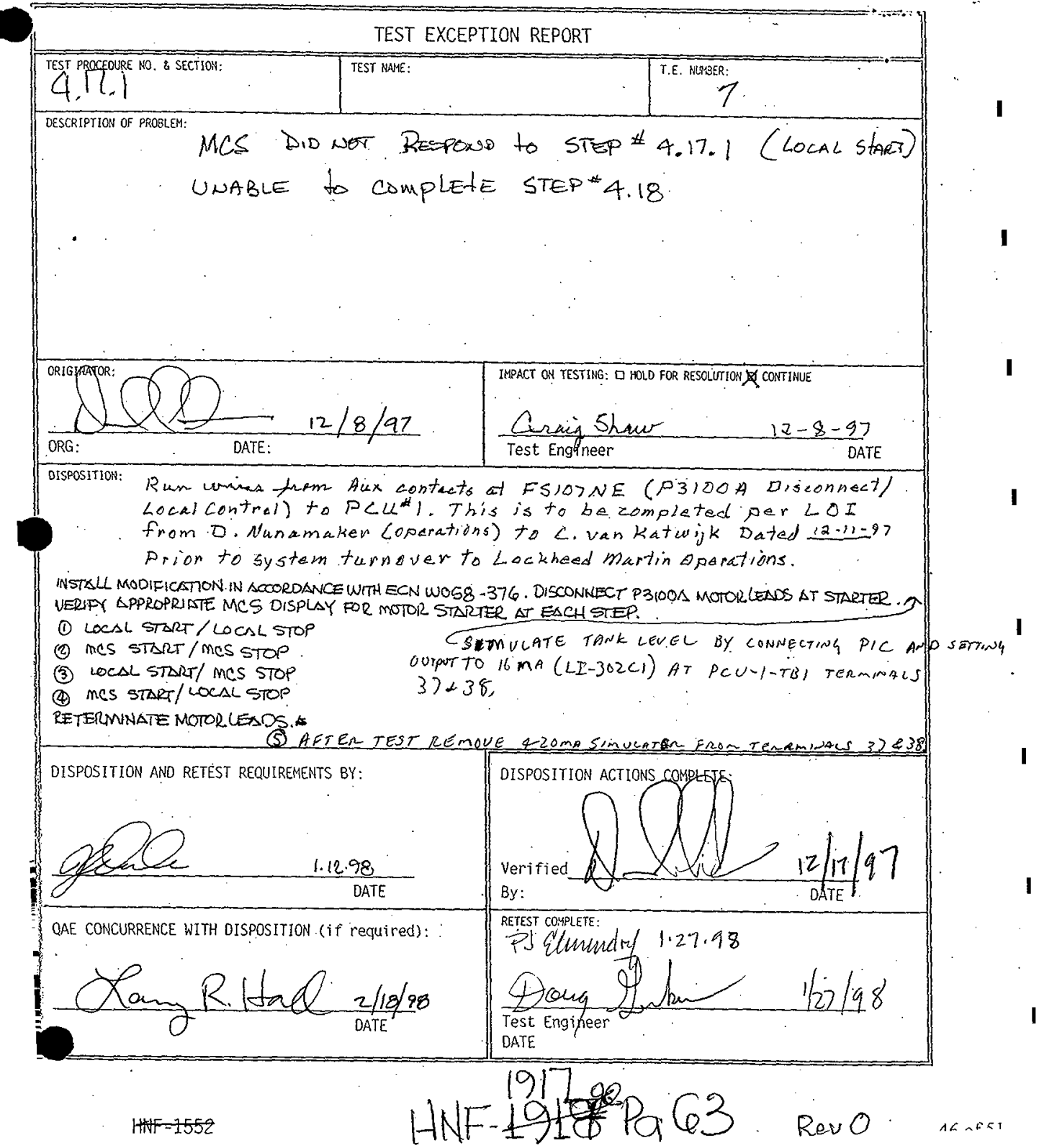




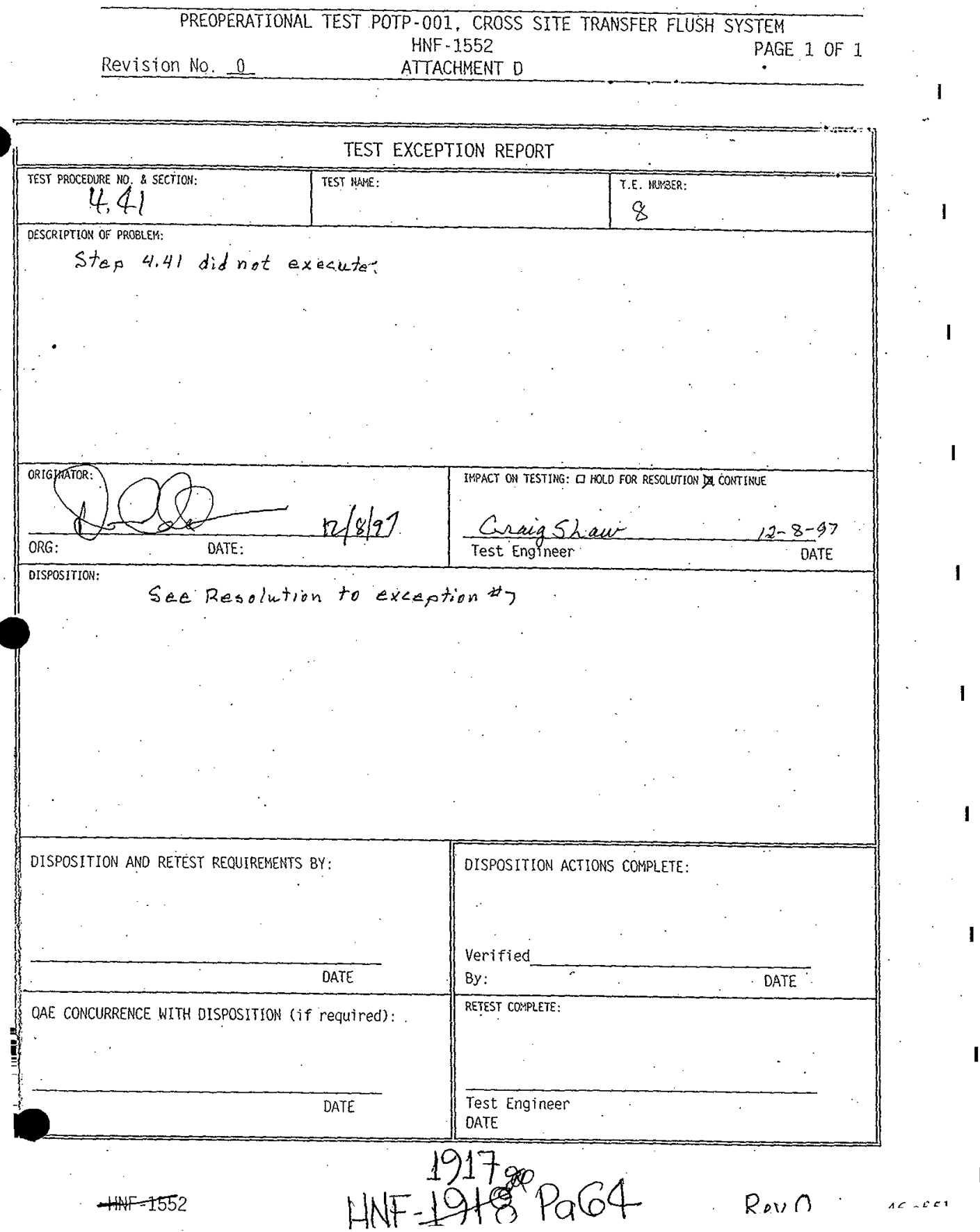




PREOPERATIONAL TEST POTP-001, CROSS SITE TRANSFER FLUSH SYSTEM
HNF-1552
ATTACHMENT D

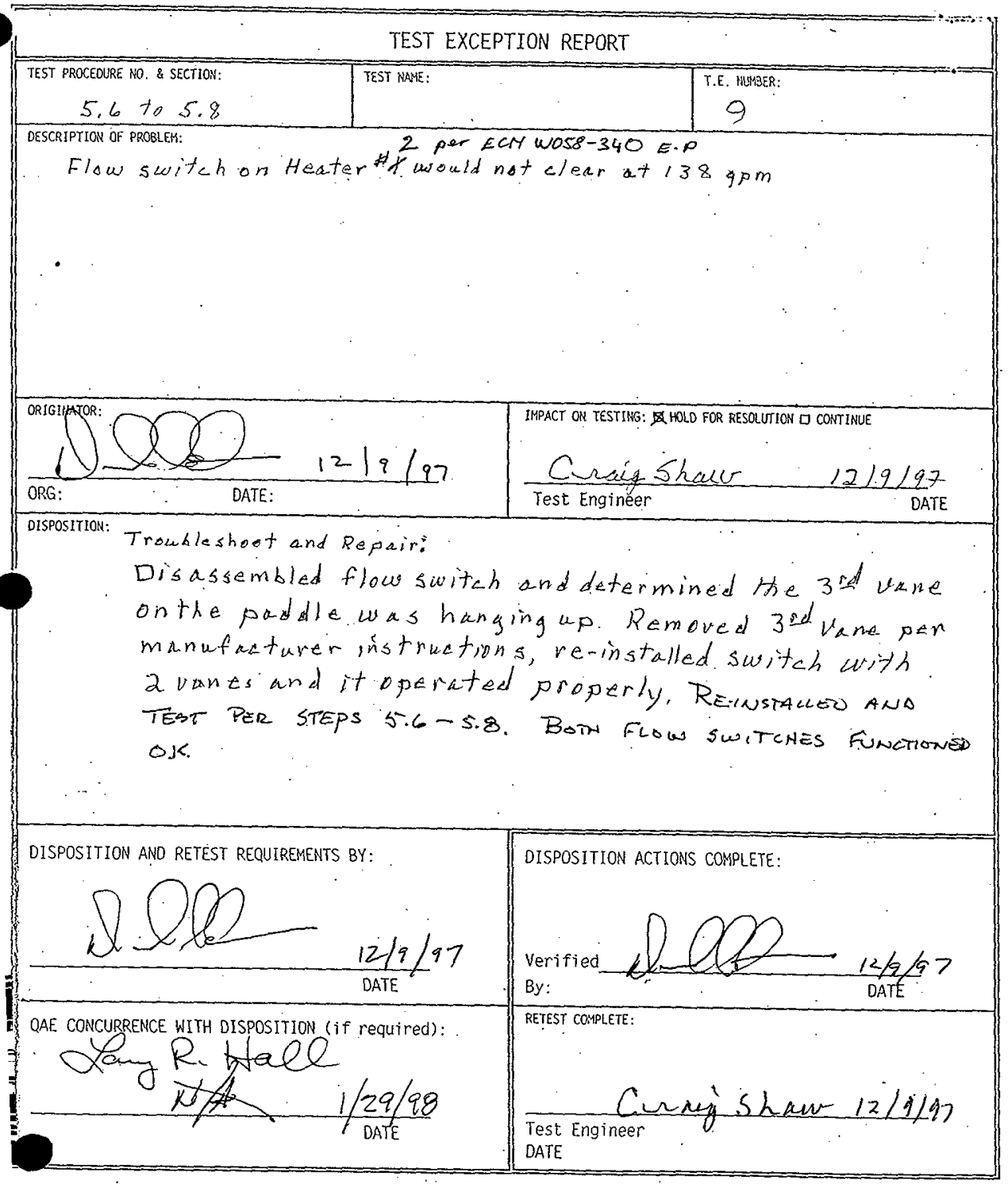

$$
H+1552
$$$$
\text { HNF-1917 Pg65 Revo n.... }
$$ 


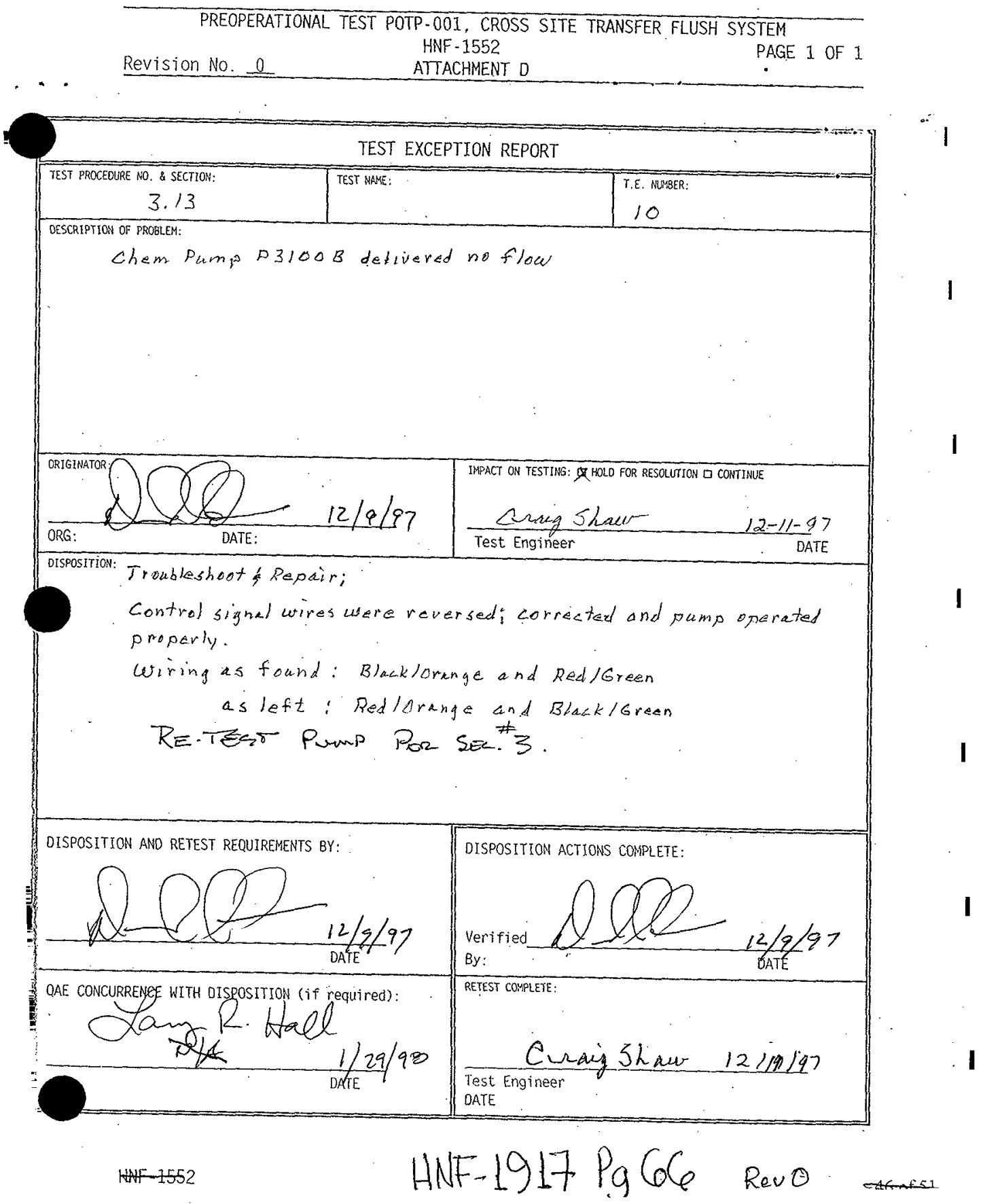


Cenfiguration for Testing

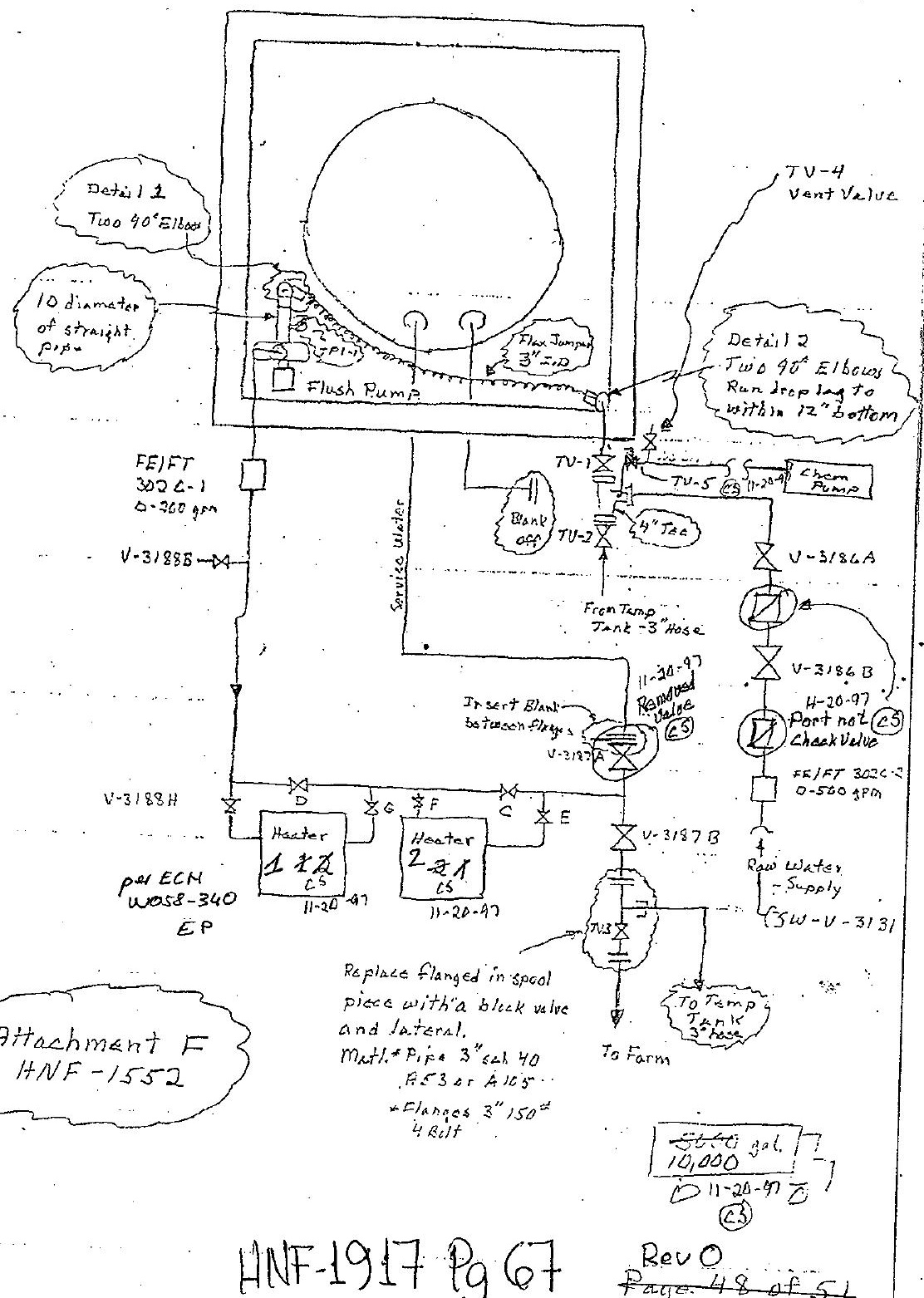




\section{Installation}

1. Install the calibralion column verlically in the suction tine betweon the motering pump and the feed tank as showr. Since the celibration column is filied by gravily, tho feed lank musi havo sulficiont volune in order lo perform an accurate calibration lest.

2. Two cuslomer supplied full.porl ball yalves must be installed as shown. (Those aro availablo lroin Hydrollo.)

3. Install a venvoverllow line to feod lanix as shown. This line musi nol be vạlveo.

Noto: Nover uso a calibrallon column on tho dischargo sldo of a pump. Thls le not a prossure vassel - maximum pressuro is 20 psig. Thls unit must be venied to almosphore vhen in use.

\section{Operating Instructions}

A sloowstcin (or a wristwatch with an accurale second hand) and a callbration column sizod lo a minimum of a 15 second run are requirod for the procedure bolow.

With sufflctont fluld lovel in the fees tonk, valvo A open, and thio pump operaling normally, open valye $B$ to thithe calibration column.

2. Clase valvo $A$ whon liquid lavel in calibration column reachos zoro mark and siarl slopwalch. Allow llquld level in column lo drop for a minimum of is seconds beforc opening valvo $A$,

\section{Hydroflo Dellvers.}

A Siydrollo, cuslomer salisloction has always beon our lirst concern. lis why wave designed all ol our producls lo glve you troublo-fseo pcilormanco. low mainienanct, and oxtrerno accuracy. And il's why wo offor last cielivery - nearly all of out producls can bo delivered wilhin a week, with one-day dolivery avaliablo whon noeded.

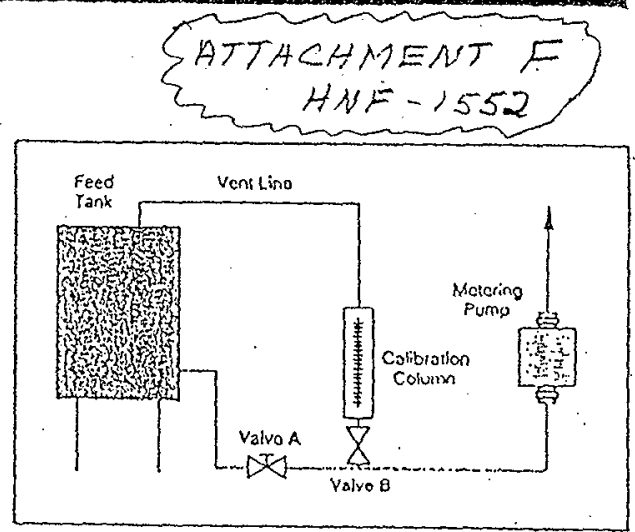

Typical installation
3. Divide the number of incroments that tho fluid has ctropped by tho number of seconds of the lest, and mulliply by the faclor shown on the calibration column dala plate lo calculate the flow race.

4. When the calibration columr is nol in uso it should bo tseo of process lluid and valvo 0 should bo kapl closed, Valve A should remain open al all thes $\cdots$ excepi white. perlorming calibration losis.
- MolcringPumps

- Tanks

- Agllators

- Dissolving Baskels

- Gauge Giasses

- Pulsalion Darnpeners

Your representallvals...
- Salely Rellel Valves

- Backpressure Valves

- Picssuro Gaugos

- Calioration Colunins

- Valves

- Strainers

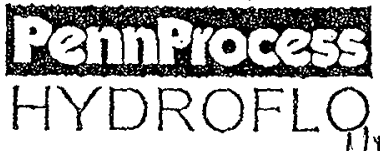

Pern Process Technologies, linc. 6100 Easton Rozd, 8.0. Box 427 Plumsteadville, PA 18949.0127 Plione: $(215) \% 66.7766$

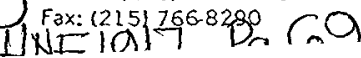

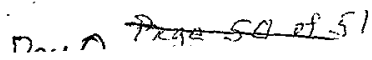




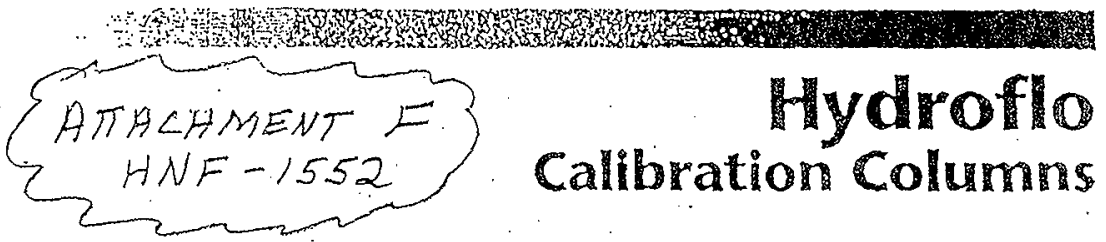

\section{Features}

- rull transparene viow ol lluid leval.

- Easy lo sizo and install.

- Riugged PVC construclion.

- Easylo clean.

- Sizos for mosl pumping requirements.

Hydrollo Calibration Columns ofler eflicient, economical flow verilicalion boyond the range of ordinacy columns.

Dosignod to check tho flows rates of chemical melering pumps, Hydrollo Catibration Columns provide fasl, teliablo porformance, easy oporation, and easy installation.
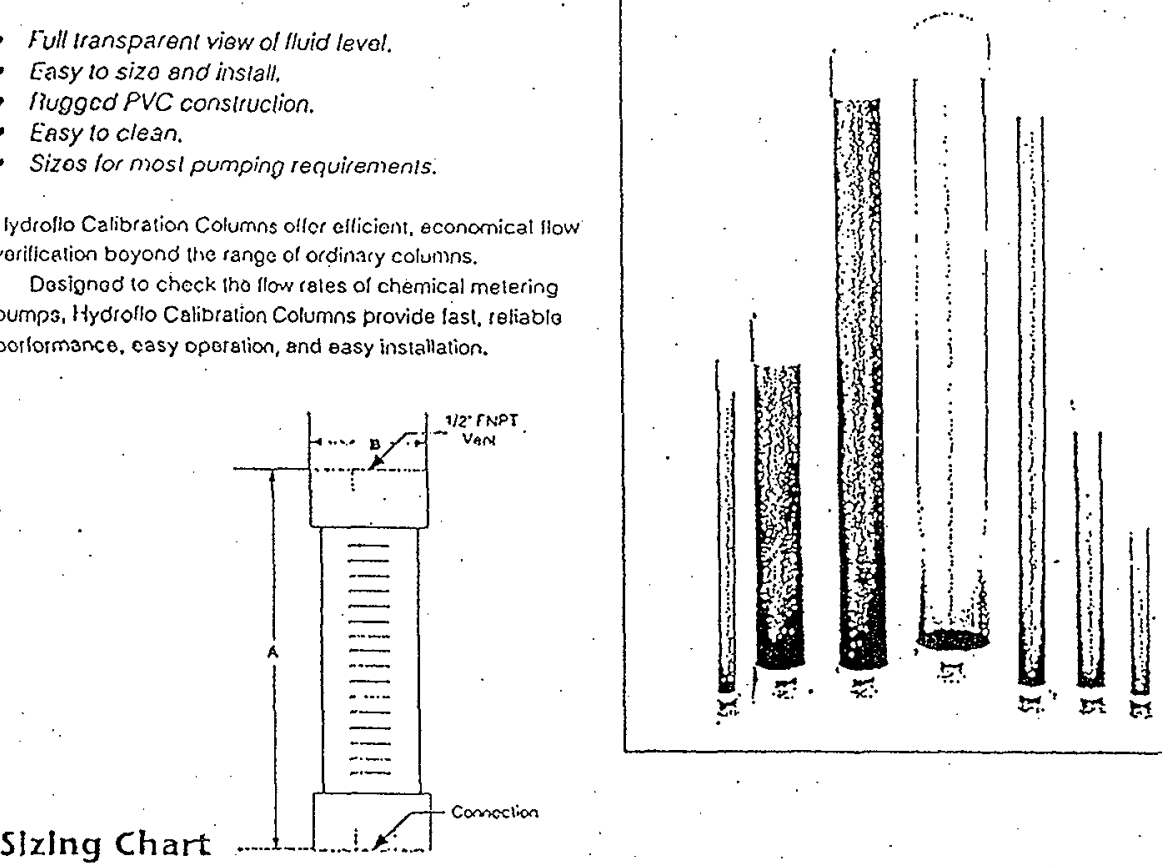

\begin{tabular}{|c|c|c|c|c|c|}
\hline $\begin{array}{l}\text { Model } \\
\text { Number }\end{array}$ & $\begin{array}{l}\text { Column } \\
\text { Capacity }\end{array}$ & $\begin{array}{c}\text { Maximum* } \\
\text { Pump Capacity }\end{array}$ & $\begin{array}{l}\text { Connection } \\
\text { FNPT }\end{array}$ & $A \pm t^{\prime \prime}$ & $B$ \\
\hline 14303.1 & $250 \mathrm{ml}$ & $8.5 \mathrm{GPH}$ & $1 / 2^{*}$ & $20 \cdot 1 / 4^{*}$ & 2 \\
\hline 19303.2 & $500 \mathrm{ml}$ & $17 \mathrm{GPH}$ & $.1 / 2^{\circ}$ & $32-1 / 1^{\circ}$ & 2 \\
\hline $14304-1$ & 1000 i & 32 GPI1 & 3/4: & $29^{\circ}$ & $2.3 / 4^{\circ}$ \\
\hline 14304.2 & $2500 \mathrm{nI}$ & $78 \mathrm{GPH}$ & $3 / 4^{\circ}$ & $56-3 / 4^{*}$ & $2-3 / 4^{\circ}$ \\
\hline 14305.1 & Sliter & 150 GFI: & 2 & $38^{\circ}$ & $5-1 / 8^{\circ}$ \\
\hline 11305.2 & 10 fiter & $300 \mathrm{GPH}$ & 3 & $81.1 / 4^{\prime}$ & $5-1 / 8^{\circ}$ \\
\hline $14305 \cdot 1$ & 25 liner & $750 \mathrm{GPH}$ & i & $63.1 / 4^{\circ}$ & $7.1 / 2^{\circ}$ \\
\hline
\end{tabular}

- Maxirnum pump capacities shown ar bosco on thitly sccond lost. ll ono minule lest is desited, decrease lisled capacities by $1 / 2$. Calibcatlon column blzing basod on usablo scajo longth. 


\begin{tabular}{|c|c|c|c|c|c|c|}
\hline \multirow{3}{*}{$\begin{array}{l}\text { 2. ECN Category } \\
\text { (mark one) } \\
\text { Supplemental } \\
\text { Direct Revision } \\
\text { Change ECN } \\
\text { Temporary } \\
\text { Standby } \\
\text { Supersedure } \\
\text { Cancel/Noid }\end{array}$} & \multirow{3}{*}{$\begin{array}{r}{[x]} \\
{[]} \\
{[]} \\
{[]} \\
{[]} \\
{[]} \\
{[]}\end{array}$} & \multicolumn{2}{|c|}{$\begin{array}{l}\text { 3. Originator's Name, Organization, MSIN, } \\
\text { and Telephone No. } \\
\text { Craig Shaw, 08E00, R3-47, 372- } \\
1757\end{array}$} & \multicolumn{2}{|c|}{$\begin{array}{l}\text { 4. USQ Required? } \\
\text { [] Yes [X] No }\end{array}$} & $\begin{array}{l}\text { 5. Date } \\
12 / 22 / 97\end{array}$ \\
\hline & & \multicolumn{2}{|c|}{$\begin{array}{l}\text { 6. Project ritle/No./Work order No. } \\
\text { W-058 Flush System }\end{array}$} & \multicolumn{2}{|c|}{$\begin{array}{c}\text { 7. Bldg./Sys./Fac. No. } \\
302 \mathrm{C}\end{array}$} & $\begin{array}{c}\text { 8. Approval Designator } \\
\text { SQ }\end{array}$ \\
\hline & & \multicolumn{2}{|c|}{$\begin{array}{l}\text { 9. Document Numbers Changed by this ECN } \\
\text { (includes sheet no. and rev.) } \\
\text { Preoperational Testing, } \\
\text { P0TP001, Water Flush System } \\
\text { HNF-1552, Rev 0 }\end{array}$} & \multicolumn{2}{|c|}{$\begin{array}{l}\text { 10. Related ECN No(s). } \\
\text { NA }\end{array}$} & $\begin{array}{l}\text { 11. Related PO No. } \\
\text { NA }\end{array}$ \\
\hline \multirow{2}{*}{\multicolumn{2}{|c|}{$\begin{array}{l}\text { 12a. Modification Work } \\
\text { [] Yes (fill out Blk. } \\
\text { 12b) } \\
{[x] \text { No (NA } 8(\mathrm{ks} .12 \mathrm{~b} \text {, }} \\
12 \mathrm{c}, 12 \mathrm{~d} \text { ) }\end{array}$}} & \multirow[t]{2}{*}{$\begin{array}{l}\text { 12b. Work Package } \\
\text { No. } \\
\text { NA }\end{array}$} & \multicolumn{2}{|c|}{$\begin{array}{l}\text { 12c. Modification Work Complete } \\
\text { NA }\end{array}$} & \multicolumn{2}{|c|}{$\begin{array}{c}\text { 12d. Restored to Original Condi- } \\
\text { tion (Temp. or Standby ECN only) } \\
\text { NA }\end{array}$} \\
\hline & & & \multicolumn{2}{|c|}{$\begin{array}{l}\text { Design Authority/Cog. Engineer } \\
\text { Signature \& Date }\end{array}$} & \multicolumn{2}{|c|}{$\begin{array}{c}\text { Design Authority/Cog. Engineer } \\
\text { Signature \& Date }\end{array}$} \\
\hline
\end{tabular}

14a. Justification (mark one)

Criteria Change [] Design tmprovement

As-Found

[]

Facilitate const

[] Environmental

[]

Facility Deactivation []

14b. Justification Details

[] Const. Error/Omission

[x]

Design Error/Omission

This ECN corrects errors/omissions in the test procedure uncovered during testing.

15. Distribution (include name, MSIN, and no. of copies)

Craig Shaw R3-47

Dave Greenaway T4-08

Curt Reichmuth T4-07

Eric Pacquet R3-47

Greg Parsons R3-47

Lanny Hall R3-47

C. van Katwijk R3-47
MJ SUTEY T4-08

pey.jice Rl-2q

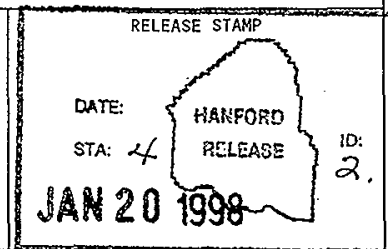

A-7900-013-2 (05/96) GEF095

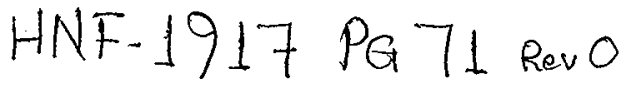

A.7900.013.1 


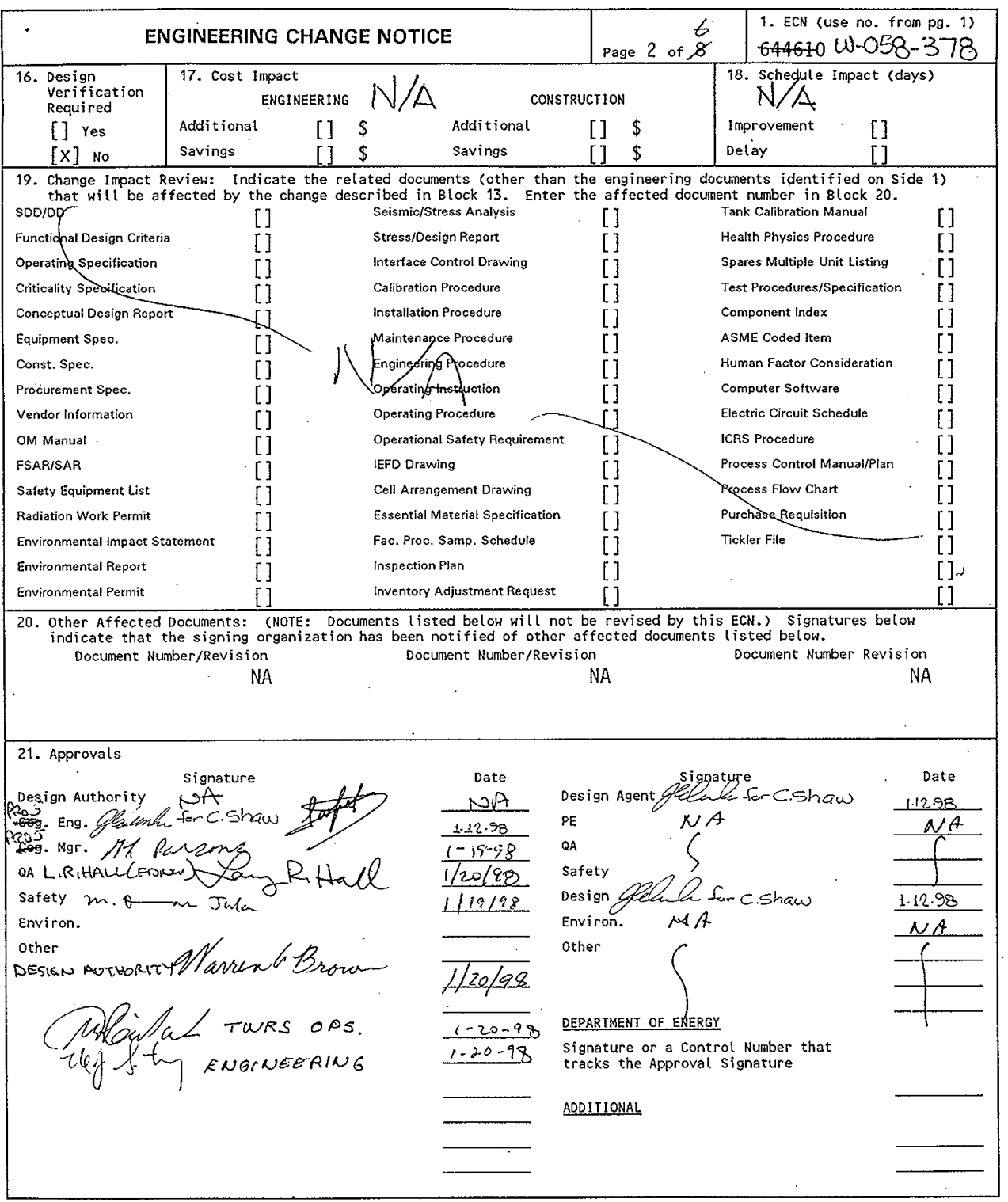

\section{HNF-1917 PG72 Revo ATIMU?}


1) Delete section 4.10.10 (thermometer not needed, delta $T$ across heaters not required)

2) Section 6.3: replace the word ..."flowing"... with ..." in the test tank"..., and ..140... with ...140+/-5 ("flowing" does not describe the test objective which was to raise the tank temperature)

3) Section 6.4 : change the word ..."service"... to ..."raw"... (changed to match field 7abe $7 s$ )

\section{ATTACHMENT A}

1) In section 1.8 change "water drum" to "bucket"

2) Delete section 1.10 (discharge attached to piping per sketch)

3) In section 1.11 change "PRV-302C-4" to "PRV-302C-3"

4) Between section 2.0 and 2.1 insert section 2.01 that reads: "Manually set pump P$3100 \mathrm{~B}$ to $100 \%$ capacity by using a PIC to supply a $20 \mathrm{ma}$ signal" (without raw water flow the pump would stay at $0 \%$ )

5) Between section 2.5 and 2.6 insert section 2.05 that reads: "Remove PIC and reconnect pump P-3100B"

In section 2.9 change "239/sec" to read "(No. of increments)/(Time(sec)) $\times 8.91 "$. (equation changed to that provided on the Hydroflo calibration column)

7) In section 2.13 change "239/sec" to read "(No. of increments)/(Time(sec)) $\times 8.91 "$.

8) In section 2.17 change "239/sec" to read "(No. of increments)/(Time(sec)) $\times 8.91 "$ ".

9) In section 2.21 change " $239 / \mathrm{sec"} \mathrm{to} \mathrm{read} \mathrm{"(No.} \mathrm{of} \mathrm{increments)/(Time(sec))} \times 8.91 "$ "

10) Section 3.0: Delete paragraph in italics (equation changed to that provided on the Hydroflo calibration column, explanation in this paragraph no longer needed)

11) Section 3.1, change " $823: 1 "$ to $163 \%$ (the MCS does not recognize the volume ratio of water to caustic, but rather ma. from flowmeter to ma into caustic pump)

12) Section 3.6, delete line "Service Water Totalizer........" (not needed, total flow measured at MCS)

13) Section 3.8: delete the Tine with "Service Water Pressure..."

14) Section 3.9 , change "MCS" to "FIC-302C-2"

15) Section 3.15.2, delete "Empty Cal. column Sec" and "ratio". Add: "(No. of increments $) /($ Time $(\mathrm{sec})) \times 8.91=$ Hydroflo calibration column)

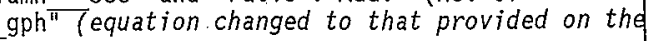

16) Section 3.17: delete the line with "Service Water Pressure..." 
17) Section 3.18 , change "MCS" to "FIC-302C-2"

18) Section 3.18: change FE/FT-302C to FE/FT-302C-2

19) Section 3.24.2, delete "Empty Cal. column Sec" and "ratio". Add: "(No. of increments $) /($ Time $(\mathrm{sec})) \times 8.91=$ $\mathrm{gph}^{\overline{1}}$

20) Section 3.25: change 150 to 170.

21) Section 3.33.2, delete "Empty Cal. column Sec" and "ratio". Add: "(No. of increments $) /($ Time $(\mathrm{sec})) \times 8.91=$ $\mathrm{gph}^{\pi}$

22) Delete section 3.34 to 3.42 . (these steps would have tested the caustic addition pump beyond its capacity)

23) Delete section 4.10 .1 (not consistent with MCS operation)

24) Change section 4.17 to read: "Bump the flush pump P-3100A by pressing local START button and verify correct rotation". (rotation had not been checked prior to test)

25) Insert section 4.17.1 that reads: "Start pump P-3100A by pressing local START button and operate until air is purged from test loop".

26) Delete sections 4.27 thru 4.31. (these steps were beyond calibration range of flowmeter)

27) Appendix A - add the following instruments:

TIC $-302 \mathrm{C}-4 \mathrm{~F}$

TIC $-302 C-4 D$

Sheath High Limit Control

TIC $-302 C-4 \mathrm{E}$ Process High Limit Control

TIC $-302 C-4 C$ Sheath High Limit Control

TPI-1 Process High Limit Control Pump Suction Pressure

28) Appendix B - change SW-V-3115 to SW-V-3195

29) Appendix $B$ - add the following valves:

SW-V-3198 SW Pressure Gage Isolation Valve

OPEN

TV -5 Temp Chem Pump Block Valve

CLOSED

$\checkmark-302 C-2$

Heater \#2 drain valve

CLOSED

NO TAG

Heater \#1 drain valve

CLOSED

$\checkmark-302 C-8$

Chem Pump Supply valve

OPEN

30) Change 4.1 to read "Adjust software to by pass tank $302 \mathrm{C}$ low level input from LIT302C-1." (simplified testing)

31) Delete $4.2,4.3,4.18$ (4.18 deleted for same reason as 4.10.1)

32) Sec 4.37 - delete "Refer back to Sec 4.1,4.2,4.3 where the PIC was set at 16mA to allow pump P-3100A to operate." add "Remove software by pass from sec 4.1 ". (simplified testing) 
33) Sec 5.0 - Delete the following words from the paragraph....."45 gpm 1atch-22 gpm unlatch". (not consistent with flow switch final configuration, see exception 9)

34) Change 5.1 to read "Adjust software to by pass tank 302C Tow level input from LIT302C-1." (simplify testing)

35) Add sec - "5.2.13CTose disconnect for pump P-3100A"

36) Add sec - "5.4.1 Stop pump locally"

37) Add sec - "5.4.2 Start pump remotely"

38) Add sec - "5.5.1 Energize Heaters"

39) Add sec - "5.5.2 Turn on heater control circuit"

40) Add sec - "5.6.1 Verify heaters de-energize"

41) In sec 5.7 delete ....(22 gpm+/-5)...(not consistent with flow switch final configuration, see exception 9)

42) Add sec - "5.8.1 Verify heaters de-energize"

43) In $\sec 5.9$ delete $\ldots(45 \mathrm{gpm}+/-5) \ldots$ (not consistent with flow switch final configuration, see exception 9$)$

44) Add sec - "5.14.1 Reset sheath and process over temperature"

45) Change 5.16 to read: "VERIFY circulation heater \#1 DOES NOT ENERGIZE by observing that no amperes are drawn."

46) Change 5.18 to read: "VERIFY circulation heater \#1 ENERGIZES by observing amperes are drawn."

47) Delete the following sections: $5.19,5.20,5.21,5.22,5.23$ (simplify testing, these were actual $7 y$ verified in steps 5.6 thru 5.9)

48) Change 5.25 to read: "VERIFY circulation heater \#1 ENERGIZES by observing amperes are drawn."

49) Change 5.32 to read: "VERIFY circulation heater \#1 ENERGIZES by observing amperes are drawn."

50) In $\sec 5.13 .2$ change TI-302C- 2 to TE-302C-2

51) In sec 5.34 .1 change $\mathrm{TAH}-302-1 \mathrm{~B}$ to $\mathrm{TAH}-302 \mathrm{C}-1 \mathrm{~A}$

52) In sec 5.39 .1 change $\mathrm{TAH}-302-1 \mathrm{~B}$ to $\mathrm{TAH}-302 \mathrm{C}-1 \mathrm{~A}$

53) Add sec - "5.43.1 Reset sheath and process over temperature"

54) Change 5.46 to read: "VERIFY circulation heater \#1. ENERGIZES by observing amperes are drawn." 地. 120148

55) In sec 5.48 .1 change ...TAH-30Z-1B... to ...TAH-302C-1A... $302^{c}$

A-7900-013-4 (04/94) GEF094 
56) Delete the following sections: $5.54,5.55,5.55$ (error in original test plan, steps not needed)

57) Add sec - "5.59.1 Reset ATarms"

58) Add sec - "5.59.2 Turn on heater control circuit"

59) Change 5.62 to read: "VERIFY circulation heater \#2 DOES NOT ENERGIZE by observing that no amperes are drawn."

60) Change 5.64 to read: "VERIFY circulation heater \#2 ENERGIZES by observing amperes are drawn."

61) Delete the following sections: 5.65 to 5.69 (simplify testing, these were actually verified in steps 5.6 thru 5.9)

62) Change 5.71 to read: "VERIFY circulation heater \#2 ENERGIZES by observing amperes are drawn."

63) Change 5.78 to read: "VERIFY circulation heater \#2 ENERGIZES by observing amperes are drawn."

$$
\text { EP } 120198
$$

64) In sec 5.80 .1 change $T A H-302 C-1 \stackrel{A}{B}$ to...-1AB

65) In $\sec 5.85 .1$ change $\ldots$-1A to $\ldots-1 B$

66) Change 5.92 to read: "VERIFY circulation heater \#2 ENERGIZES by observing amperes are drawn."

67) In $\sec 5.94 .1$ change $\ldots-1 \mathrm{~A}$ to $\ldots-1 \mathrm{~B}$

68) In sec 5.99 .1 change $\ldots-1 \mathrm{~A}$ to $\ldots-1 \mathrm{~B}$

69) Delete 5.100 (error in original test plan, step not needed)

70) In sec 5.101 .1 change TI-302C $-\not 3$ to $\mathrm{TE}-302 \mathrm{C}-2$

71) Change 5.104: Operate heaters unti water reaches $140 \mathrm{~F}+/-10$ on temporary water tank.

72) Delete 5.107 (step not needed, afterheat remova7 not a problem)

73) Change 6. Th to read: VERIFY Sump Pump P-302C-3 transfers water in its final approved configuration.

74) Delete $\sec 6.2$ to 6.8 (change in step 6.1 made them unnecessary) 


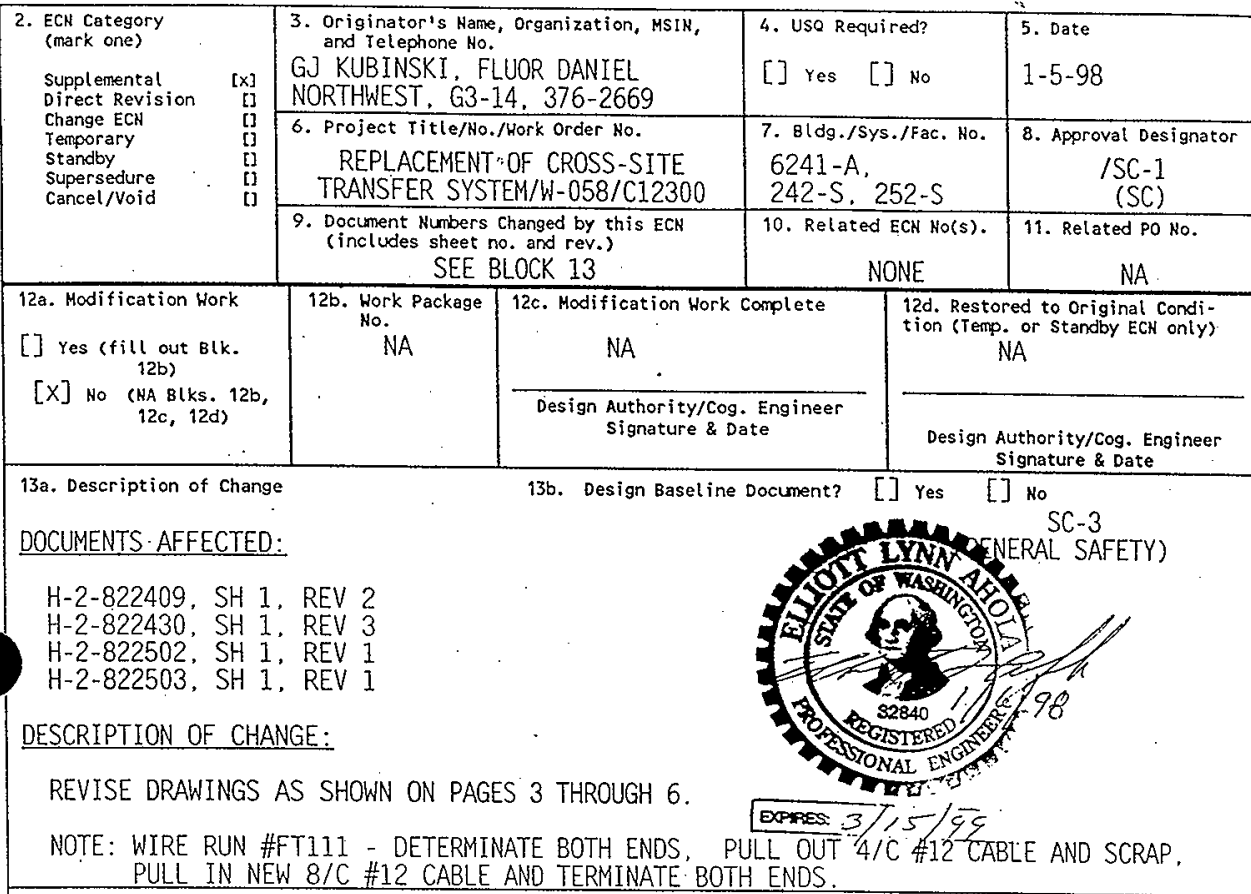

14a. Justification (mark one)

Criteria Change $[X]$ Design improvement [] Environmental [] Facility Deactivation []

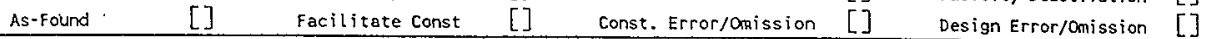

14b. Justification Details

ADO LOCAL RUN STATUS FOR FLUSH PUMP P3100A PER CUSTOMER REQUEST.

15. Distribution (include name, MSIN, and no, of copies)

RELEASE STAMP 


\section{ELUOR DANIEL NORTHWEST, INC. ENGINEERING CHANGE NOTICE SKETCH}

\begin{tabular}{|c|c|c|c|c|c|c|}
\hline $\mathrm{H}-2$ & $\begin{array}{c}\text { sn. } \\
1\end{array}$ & $\begin{array}{r}\text { Rev. } \\
2\end{array}$ & $\begin{array}{l}\text { Prepared By } \\
\text { GJ KUBINSKI }\end{array}$ & 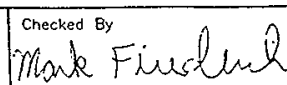 & $\begin{array}{l}\text { ECN No. } \\
W-058=376\end{array}$ & $\begin{array}{l}\text { Page } \\
3 / 6\end{array}$ \\
\hline
\end{tabular}

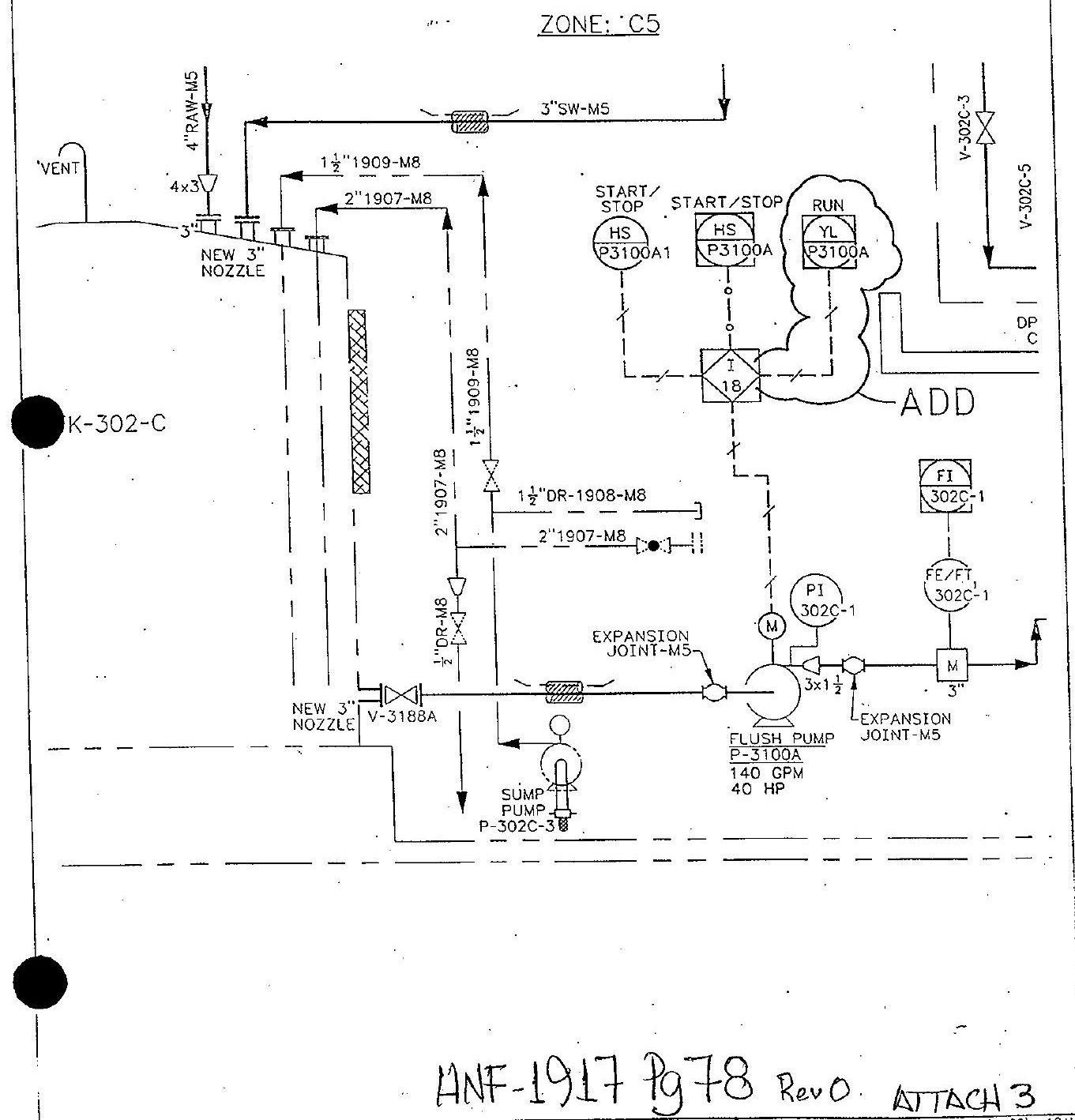


FLUOR DANIEL NORTHWEST, INC.

ENGINEERING CHANGE NOTICE SKETCH

\begin{tabular}{|c|c|c|c|c|c|c|}
\hline$-2-822430$ & $\begin{array}{r}\text { sn. } \\
1\end{array}$ & $\begin{array}{r}\text { Rev. } \\
3\end{array}$ & $\begin{array}{l}\text { Prepared By } \\
\text { GJ KUBINSKI }\end{array}$ & checked By & $\begin{array}{l}\text { ECN No. } \\
W-058-376\end{array}$ & $\begin{array}{l}\text { Page } \\
4 / 6\end{array}$ \\
\hline
\end{tabular}

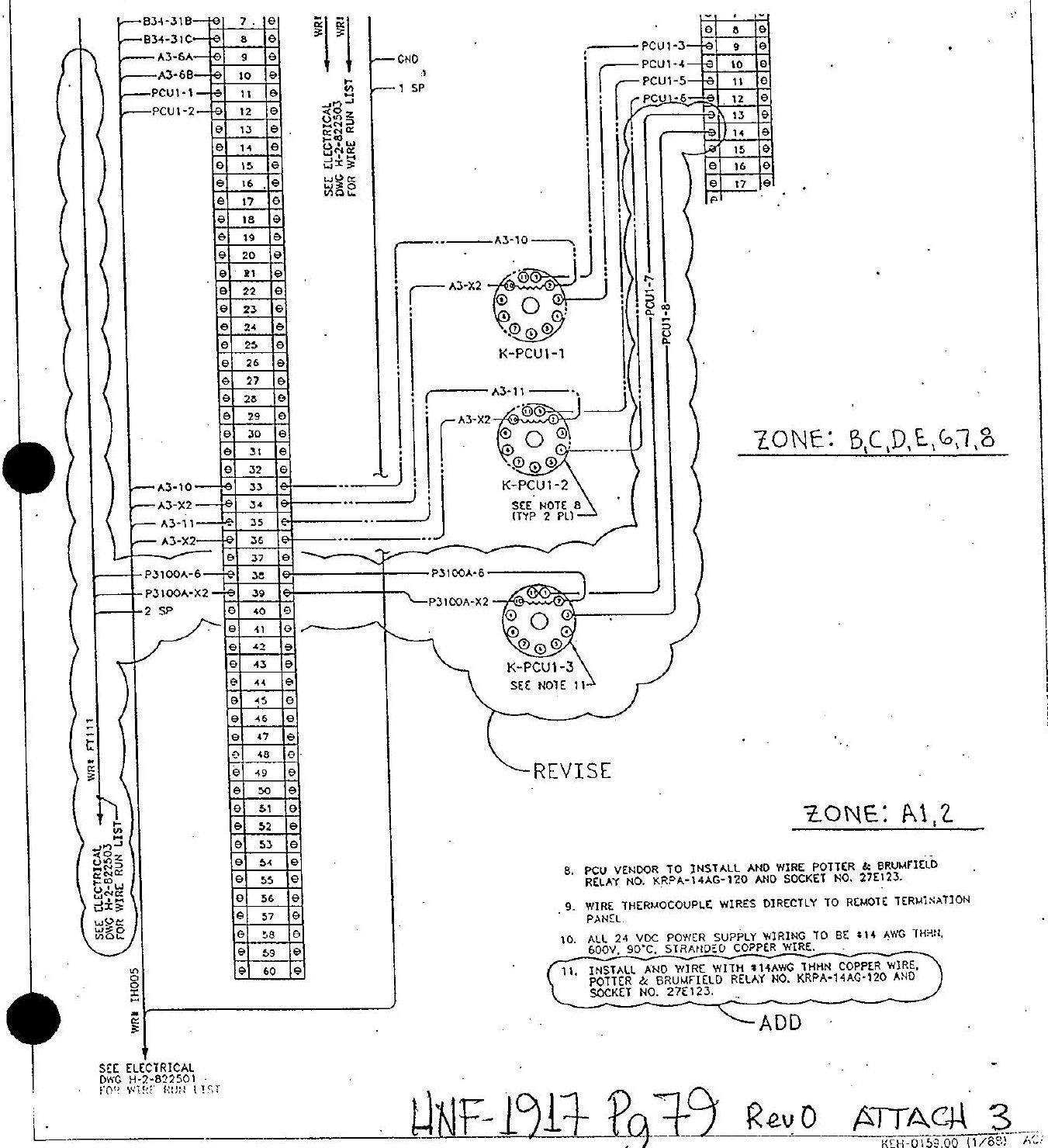




\section{ELUOR DANIEL NORTHWEST, INC.}

\section{ENGINEERING CHANGE NOTICE SKETCH}

\begin{tabular}{|c|c|c|c|c|c|c|}
\hline $\mathrm{H}-2-8225$ & $\begin{array}{c}\text { sh, } \\
1\end{array}$ & $\begin{array}{r}\text { Rev. } \\
1\end{array}$ & $\begin{array}{l}\text { Prepared 8y } \\
\text { GJ KUBINSKI }\end{array}$ & Checked By & $\begin{array}{l}\varepsilon C N \text { No. } \\
W-058-376\end{array}$ & \begin{tabular}{|l|} 
Page \\
$5 / 0$
\end{tabular} \\
\hline
\end{tabular}

ZONE: D6, D7

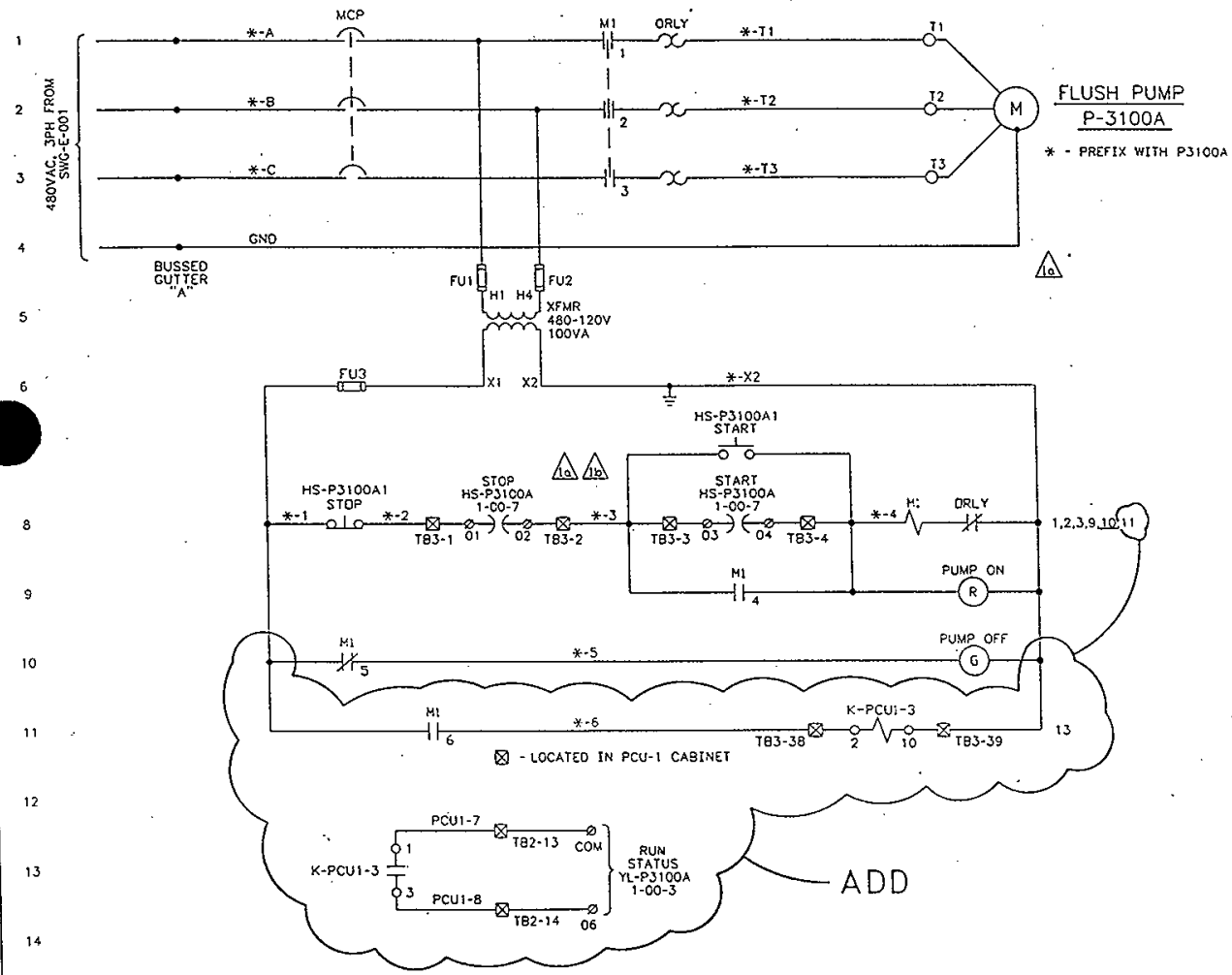




\section{FLUOR DANIEL NORTHWEST, INC. ENGINEERING CHANGE NOTICE SKETCH}

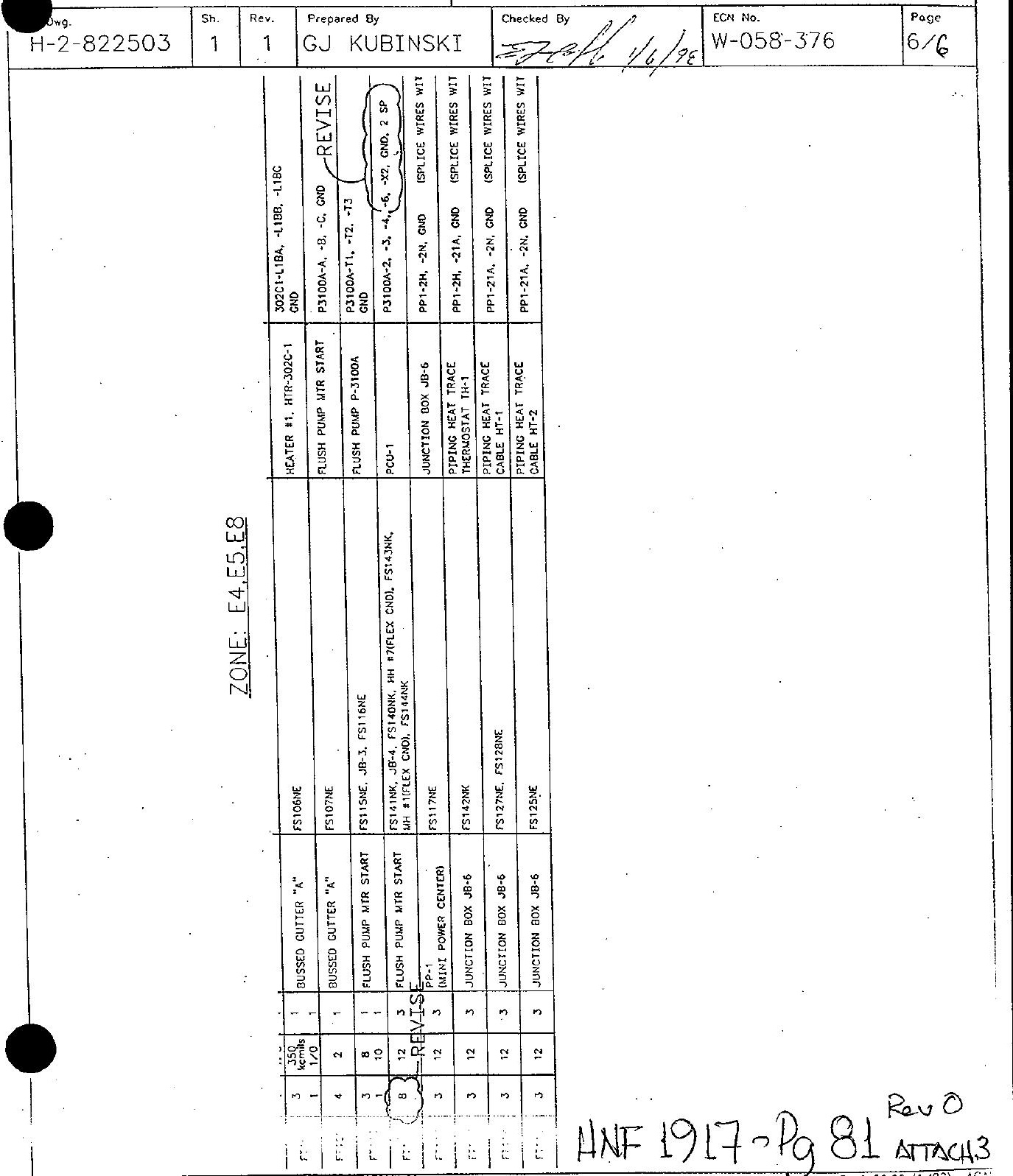




\section{ATTACHMENT - 4}

\section{MCS CAUSTIC RAW WATER FLOW RATIO SETTING}

1) Reference \# 3 (Calculation No. W058-P-050, pH Adjustment of Water Using Sodium Hydroxide/Pump Injection rate.), on page 4, specifies that at raw water flow rate of 170 gpm the required caustic flow is $12.4 \mathrm{gph}$ to raise the $\mathrm{pH}$ to 11 .

2) The MCS receives a 4-20mA signal from raw water flowmeter (FE/FT-302C-2) and sends a 4-20mA signal to caustic pump (P3100B)

In order to obtain the desired raw water to caustic flow ratio the corresponding $\mathrm{mA}$ signal ratio must be entered at the MCS.

\begin{tabular}{|l|l|l|l|}
\hline & DEVICE & FLOW RANGE & SIGNAL RANGE \\
\hline Raw water & FE/FT-302C-2 & $0-350 \mathrm{gpm}$ & $4-20 \mathrm{~mA}$ \\
\hline Caustic & P3100B & $0-13 \mathrm{gph}$ & $4-20 \mathrm{~mA}$ \\
\hline & & & \\
\hline
\end{tabular}

To obtain a caustic flow of $12.4 \mathrm{gph}$ for a raw water flow of $170 \mathrm{gpm}$ in order to raise the $\mathrm{pH}$ to 11 , the MCS ratio setting is calculated as follows:

$\mathrm{R}=[(12.4 / 13) \times 16+4] /[(170 / 350) \times 16+4]$

$\mathrm{R}=19.3 \mathrm{ma} / 11.8 \mathrm{ma}$

$\mathrm{R}=1.63$

$\mathrm{R}=163 \%$ 
HNF-1917

ATTACHMENT - 5

PUMP P3100A PERFORMANCE DESIGN POINT

The required performance of pump P3100A: @140 gem TDH >240 ft.

From Appendix D-1 data, @139gpm: suction pressure = -9.0" $\mathrm{Hg}$ and discharge pressure = 100 prig.

TDH is the difference between suction pressure and discharge pressure measured in feet of fluid flowing.

Discharge: $\quad 100 \mathrm{psi} \times 2.31 \mathrm{ft}-\mathrm{H}_{2} \mathrm{O} / \mathrm{psi}=231 \mathrm{ft}-\mathrm{H}_{2} \mathrm{O}$

Suction: $\quad 14.7 \mathrm{psi} / 29.92 \mathrm{hg} \times-9.0^{\mathrm{h}} \mathrm{hg} \times 2.31 \mathrm{ft}-\mathrm{H}_{2} \mathrm{O} / \mathrm{psi}=-10.2 \mathrm{ft}-\mathrm{H}_{2} \mathrm{O}$

TDH: $\quad 231-(-10.2)=241.2 \mathrm{ft}-\mathrm{H}_{2} \mathrm{O}$

HNE-1917 Pg $83^{\operatorname{Rev} O} \Delta T T \Delta C H 5$ 


\section{W-058 Interlock Test Listing}

INTERLOCK LOGIC (H-2-822400, Sh 1, Rev 5)

1. If a leak is detected shutdown operating Booster Pump, P-3125A or P-3125B, Transfer Pump P-102-SY-02A, and input signal to 200 West Master Pump Circuit. (Software)

2. On high pressure shutdown operating Booster Pump, P-3125A or P-3125B. (Software)

T.

3. $\frac{Z}{T}$

44. I Sump pump will not be permitted to operate if associated outlet valve is not 1 open. (Software)

5. 1 On positive pressure (gage), in transfer line, vent valves will not be permitted to open. (Software)

T)

16. I The operating Booster Pump, P-3125A or P-3125B, will shutdown:

A) On high pump bearing temperature. (Software)

B) On high motor winding temperature. (Software)

$f_{C}$ ) On high vibration. (Software)

D) On pump sear failure. (Software)

E) On low oil level. (Software)

$\mathrm{X}$ ) On local control. (Software)

7. The Booster Pump will not be permitted to operate if the inlet pressure is lower Than 10psig. (Software)

8. I Shutdown operating Booster Pump when rupture disk PSE 841 or PSE 842 fails. $6)^{\text {(Software) }}$

19. Transfer Pump P-102-SY-SY-02A, will not be permitted to operate if operating Booster Pump is shutdown. (Software)

\section{$(1 / 14 / 98)$}

10. Upstream transfer pump P-102-SY-02A, will be shutdown if inlet pressure reaches 70 psig. (Software)

11. On leak detection, shutdown Booster Pump P-3125A and P-3125B. (Hardwired)

12. On leak detection, shutdown Transfer Pump P-102-SY-02A. (Hardwired)

13. On leak detection, input signal to 200East and 200West Master Shutdown Circuits. See Drawings H-2-822440 sh1 and 442 sh 1 . (Hardwired)

14. On high discharge pressure shutdown appropriate operating pump. (Software)

15. The Booster Pump will not be permitted to operate is the associated vent and drain valves are not closed. (Software)

16. On high pressure, input signal to 200West Master Shutdown circuits. (Hardwired)

17. If valve is open, input signal to 200 West Master Shutdown circuits. (Hardwired)

18. On low level, shutdown flush pump P-3100A. (Software)

19. On high process temperature, high heater sheath temperature, or low flow heater is shutdown. (Hardwired)

20. On high pressure, shutdown transfer pump P-102-SY-02A. (Software)

21. On positive pressure (gage), in transfer line, sump pump valves will not be permitted to open. (Software) 


\begin{tabular}{|c|c|c|c|c|c|c|c|c|c|}
\hline IL & SYS & DEVICE & P\&ID & ALARM & IL $\triangle$ CTION/(HW or SW) & FUNCTION & LOCATION & TESTED & COMMENTS \\
\hline 01 & SNL/SLL & LDE 3150 & 403 & LEAK & STOP P3125A/B \& 2W MPS/S & SUMP LD & DB PUMP RM & ATP004//POTP005 & $9.10(\mathrm{~A}) / 10.10(\mathrm{~B}) / / 12(\mathrm{MPS})$ \\
\hline 01 & SNL/SLL & LDE3151 & 404 & LEAK & STOP P3125A/B \& 2W MPS/S & SUMP LD & VS VAULT & ATP004//POTP005 & $9.10(\mathrm{~A}) / 10.10(\mathrm{~B}) / / 12(\mathrm{MPS})$ \\
\hline 01 & SNL/SLL & LDE3160A & 403 & LEAK & STOP P3L25A/B \& 2W MPS/S & ENCASEMENT LD & DB ŚWGR RM & ATP004//POTP005 & $9.10(\mathrm{~A}) / 10.10(\mathrm{~B}) / / 12(\mathrm{MPS})$ \\
\hline 01 & SNL/SLL & LDE3160B & 403 & LEAK & STOP P3125A/B \& 2W MPS/S & ENCASEMENT LD & DB SWGR RM & ATP004//POTP005 & $9.10(\mathrm{~A}) / 10.10(\mathrm{~B}) / / 12(\mathrm{MPS})$ \\
\hline 01 & $\mathrm{SNL} / \mathrm{SLE}$ & LDE3 $3160 \mathrm{C}$ & 403 & LEAK & STOP P3L25A/B \& 2W MPS/S & ENCASEMENT LD & DB SWGR RM & ATP004//POTP005 & $9.10(\mathrm{~A}) / 10.10(\mathrm{~B}) / / 12(\mathrm{MPS})$ \\
\hline 01 & SNL/SLL & LDE3160D & 403 & LEAK & STOP P3125A/B \& 2W MPS/S & ENCASEMENT LD & DB SWGR RM & ATP004//POTP005 & $9.10(\mathrm{~A}) / 10.10(\mathrm{~B}) / / 12(\mathrm{MPS})$ \\
\hline 01 & SNL/SLL & LDE3161A & 404 & LEAK & STOP P3I25ABB \& 2W MPS/S & ENCASEMENT LD & VS SWGR RM & ATP004//POTP005 & $9.10(\mathrm{~A}) / 10.10(\mathrm{~B}) / / 12(\mathrm{MPS})$ \\
\hline 01 & SNL/SLL & LDE3 161B & 404 & LEAK & STOP P3125A/B \& 2W MPS/S & ENCASEMENT LD & VS SWGR RM & ATP004//POTP005 & $9.10(\mathrm{~A}) / 10.10(\mathrm{~B}) / / 12(\mathrm{MPS})$ \\
\hline 01 & SNL/SLLL & LDE3161C & 404 & LEAK & STOP P3I25A/B \& 2W MPS/S & ENCASEMENT LD & VS SWGR RM & ATP004//POTP005 & $9.10(\mathrm{~A}) / 10.10(\mathrm{~B}) / / 12(\mathrm{MPS})$ \\
\hline 01 & SNL/SLL & LDE3161D & 404 & LEAK & STOP P3125A/B \& 2W MPS/S & ENCASEMENT LD & VS SWGR RM & ATP004//POTP005 & $9.10(\mathrm{~A}) / 10.10(\mathrm{~B}) / / 12(\mathrm{MPS})$ \\
\hline 01 & SNL/SLL & LDE3162A & 405 & LEAK & STOP P3125A/B \& 2W MPS/S & ENCASEMENT LD & CAB6241 & A.TP004//POTP005 & $9.10(\mathrm{~A}) / 10.10(\mathrm{~B}) / / 12(\mathrm{MPS})$ \\
\hline 01 & SNL/SLL & LDE3162B & 405 & LEAK & STOP P3l25A/B \& 2W MPS/S & ENCASEMENT LD & $\mathrm{CAB} 6241$ & ATP004//POTP005 & $9.10(\mathrm{~A}) / 10.10(\mathrm{~B}) / 12(\mathrm{MPS})$ \\
\hline 01 & SNL/SLL & LDEPP & 405 & LEAK & STOP P3125N/B \& 2W MPS/S & LIFT STATION LD & 244A LIFT STA & POTP-004 & $9.34(\mathrm{~A})(\mathrm{MPS}) / 10.34(\mathrm{~B})(\mathrm{MPS})$ \\
\hline 02 & SLL & PT3168 & 404 & $\mathrm{P}>10 \mathrm{PSIG}$ & SHUT DOWN P3I25A OR B/S & PROTECT VS HEPA & VS VAULT & ATP-004//POTP007 & $9.10 / 10.10 / 2.37 / 3.37$ \\
\hline 02 & SLL & PT 842 & 405 & $\mathrm{P}>200 \mathrm{PSIG}$ & SHUT DOWN P3125A OR B/S & PROTECT EXST TF & 244A LIFT STA & POTP-004 & $9.49(\mathrm{~A}) / 10.49(\mathrm{~B})$ (Note 1$)$ \\
\hline 03 & SNL & LSL3102 & 401 & LEVEL LO & P102SYO2A PERMSVE/S & XFER PUMP LEVEL & SY 102 & ATP- 003 & 9.1 (Note 2) \\
\hline 04 & SNL & SOV3167A & 404 & $\neq \mathrm{OPEN}$ & INHIBIT SUMP PUMP/S & SUMP DISCHARGE & VS VAULT & POTP-005 & $11.12-11.24$ \\
\hline 04 & SNL & SOV3167B & 404 & $\neq$ OPEN & INHIBIT SUMP PUMP/S & SUMP DISCHARGE & VS VAULT & POTP-005 & $11.12-11.24$ \\
\hline 04 & SNL & SOV $3173 \mathrm{~A}$ & 403 & $\neq \mathrm{OPEN}$ & INHIBIT SUMP PP/S & SUMP DISCHARGE & DB PUMP RM & POTP-005 & $9.12-9.24$ \\
\hline 04 & SNL & SOV $3173 B$ & 403 & *OPEN & INHIBIT SUMP PP/S & SUMP DISCHARGE & DB PUMP RM & POTP-005 & $9.12-9.24$ \\
\hline 05 & SNL & РT3126A & 404 & $p>0 P S I G$ & INHIB VENT VALVE OPEN/S & SUPER PRESSURE & VS VAULT & POTP-005 & 4.0 \\
\hline 05 & SLL & $\mathrm{P} T 3126 \mathrm{~B}$ & 404 & $\mathrm{P}>0 \mathrm{PSIG}$ & INHBB VENT VALVE OPEN/S & SLURRY PRESS & VS VAULT & POTP-004 & 5.0 \\
\hline 06A & SLL & TE3125A1 & $400 / 2$ & $\mathrm{~T}>200^{\circ} \mathrm{F}$ & SHUTDOWN P3L25A/S & BP BRG TEMP & DB PUMP RM & POTP-007 & 2.26 \\
\hline 06A & SLL & TE3125A2 & $400 / 2$ & $\mathrm{~T}>200^{\circ} \mathrm{F}$ & SHUTDOWN P3125A/S & BP BRG TEMP & DB PUMP RM & POTP-007 & 2.27 \\
\hline 06A & SLL & $\mathrm{TE} 3125 \mathrm{~B} 1$ & $400 / 2$ & $\mathrm{~T}>200^{\circ} \mathrm{F}$ & SHUTDOWN P-3125B/S & BP BRG TEMP & DB PUMP RM & POTP-007 & 3.26 \\
\hline $06 \AA$ & SLL & TE3125B2 & $400 / 2$ & $\mathrm{~T}>200^{\circ} \mathrm{F}$ & SHUTDOWN P-3125B/S & BP BRG TEMP & DB PUMP RM & POTP-007 & 3.27 \\
\hline
\end{tabular}




\begin{tabular}{|c|c|c|c|c|c|c|c|c|c|}
\hline IL & SYS & DEVICE & P\&ID & ALARM & IL ACTION/(HW or SW) & FUNCTION & LOCATION & TESTED & COMMENTS \\
\hline $06 \mathrm{~B}$ & SLL & TSH $3125 \mathrm{~A}$ & $400 / 2$ & $\mathrm{D}>175^{\circ} \mathrm{F}$ & SHUTDOWN P3125A/S & BP MOTOR TEMP & DB PUMP RM & POTP-007 & 2.28 \\
\hline $06 \mathrm{~B}$ & SLL & TSH $3125 \mathrm{~B}$ & $400 / 2$ & $\mathrm{~T}>175^{\circ} \mathrm{F}$ & SHUTDOWN P-3125B/S & BP MOTOR TEMP & DB PUMP RM & POTP-007 & 3.28 \\
\hline $06 \mathrm{C}$ & SLL & VT3125Al & $400 / 1$ & $\mathrm{~V}>.6 \mathrm{IN} / \mathrm{S}$ & SHUTDOWN P3125A/S & BP VIBRATION & DB PUMP RM & POTP-007 & 2.29 \\
\hline $06 \mathrm{C}$ & SLL & VT3125A2 & $400 / 2$ & $\mathrm{~V}>6 \mathrm{IN} / \mathrm{S}$ & SHUTDOWN P3125A/S & BP VIBRATION & DB PUMP RM & POTP-007 & 2.30 \\
\hline $06 \mathrm{C}$ & SLL & VT3125B & $400 / 1$ & $\mathrm{v}>.6 \mathrm{nN} / \mathrm{s}$ & SHUTDOWN P-3125B/S & BP VIBRATION & DB PUMP RM & POTP-007 & 3.29 \\
\hline $06 \mathrm{C}$ & SLL & $\mathrm{VT} 3125 \mathrm{~B} 2$ & $400 / 2$ & $\mathrm{~V}>.6 \mathrm{NN} / \mathrm{s}$ & SHUTDOWN P-3125B/S & BP VIBRATION & DB PUMP RM & POTP-007 & 3.30 \\
\hline 06D & SLL & FSH3125Al & $400 / 2$ & $\mathrm{~F}>11 \mathrm{SCFH}$ & SHUTDOWN P3125A/S & BP SEAL AIR & DB COMP RM & POTP-007 & 2.33 \\
\hline $06 \mathrm{D}$ & SLL & FSH $3125 A 2$ & $400 / 2$ & $\mathrm{~F}>11 \mathrm{SCFH}$ & SHUTDOWN P3125A/S & BP SEAL AIR & DB COMP RM & POTP-007 & 2.34 \\
\hline 06D & SLL & FSH3 $125 \mathrm{~B} 1$ & $400 / 3$ & $\mathrm{~F}>11 \mathrm{SCFH}$ & SHUTDOWN P-3125B/S & BP SEAL AIR & DB COMP RM & POTP-007 & 3.33 \\
\hline 06D & SLL & FSH3125B2 & $400 / 3$ & $\mathrm{~F}>11 \mathrm{SCFH}$ & SHUTDOWN P-3125B/S & BP SEAL AIR & DB COMP RM & POTP-007 & 3.34 \\
\hline $06 \mathrm{D}$ & SLL & PSL3125A1 & $400 / 2$ & $\mathrm{P}<110 \mathrm{PSIG}$ & SHUTDOWN P3125A/S & BP SEAL AIR & DB COMP RM & POTP-007 & 2.35 \\
\hline $06 \mathrm{D}$ & SLL & PSL3125A2 & $400 / 2$ & $\mathrm{P}<110 \mathrm{PSIG}$. & SHUTDOWN P3125A/S & BP SEAL AIR & DB COMP RM & POTP-007 & 2.36 \\
\hline $06 \mathrm{D}$ & SLL & PSL3125B1 & $400 / 3$ & $P<110$ PSIG & SHUTDOWN P-3125B/S & BP SE $\Lambda \mathrm{L} \Lambda \mathrm{IR}$ & DB COMP RM & POTP-007 & 3.35 \\
\hline $06 \mathrm{D}$ & SLL & PSL3125B2 & $400 / 3$ & $P<110$ PSIG & SHUTDOWN P-3125B/S & BP SEAL AIR & DB COMP RM & POTP-007 & 3.36 \\
\hline $06 \mathrm{E}$ & SLL & LSL3125A1 & $400 / 2$ & LEVEL LO & SHUTDOWN P3125A/S & BP OIL LEVEL & DB PUMP RM & POTP-007 & 2.31 \\
\hline $06 \mathrm{E}$ & SLL & LSL3125A2 & $400 / 2$ & LEVEL LO & SHUTDOWN P3125A/S & BP OIL LEVEL & DB PUMP RM & POTP-007 & 2.32 \\
\hline $06 \mathrm{E}$ & SLL & LSL312SB1 & $400 / 2$ & LEVEL LO & SHUTDOWN P-3125B/S & BP OIL LEVEL & DB PUMP RM & POTP-007 & 3.31 \\
\hline $06 \mathrm{E}$ & SLL & LSL $3125 B 2$ & $400 / 2$ & LEVEL LO & SHUTDOWN P-3125B/S & BP OIL LEVEL & DB PUMP RM & POTP-007 & 3.32 \\
\hline $06 \mathrm{X}$ & SLL & HS $3125 A$ & $400 / 2$ & OFF & SHUTDOWN P3125A/S & HAND-OFF-AUTO & DB SWGR RM & POTP-007 & 7.2 .1 \\
\hline $06 \mathrm{X}$ & SLL & HS $3125 B$ & $400 / 2$ & OFF & SHUTDOWN P-3125B/S & HAND-OFF -AUTO & DB SWGR RM & POTP-007 & 8.4 .1 \\
\hline 07 & SLL & РT3125A & 403 & $\mathrm{P}<10 \mathrm{PSIG}$ & INHIBIT P3125A/S & BP-A INLET P & DB PUMP RM & POTP-007 & 2.38 \\
\hline 07 & SLL & $\operatorname{Pr} 3125 B$ & 403 & $\mathrm{P}<10 \mathrm{PSIG}$ & INHIBIT P-3125B/S & BP-B INLET P & DB PUMP RM & POTP-007 & 3.38 \\
\hline 08 & SLL & YAS841 & 405 & RD FAIL & STOP P3125A/B/S & RUPT DISK MON & $244 \mathrm{~A}$ & POTP-004 & $9.70(\mathrm{~A}) / 10.70(\mathrm{~B})$ (Note 1$)$ \\
\hline 08 & SLL & YAS842 & 405 & RDFAIL & STOP P 3125A/B/S & RUPT DISK MON & $244 \mathrm{~A}$ & POTP-004 & $9.79(\mathrm{~A}) / 10.79$ (B) (Note 1) \\
\hline 09 & SNL/SLL & P3125A or B & 403 & RUN & P102SY02A PERMSVE/S & XFER PUMP & DB PUMP RM & POTP-007 & $2.25 / 3.25$ \\
\hline 10 & SNL/SLL & PT3125A & 403 & $\mathrm{P}>70 \mathrm{PSIG}$ & STOP TRANSFER PUMP/S & BP-A INLET P & DB PUMP RM & POTP-007. & 2.38 \\
\hline
\end{tabular}




\begin{tabular}{|c|c|c|c|c|c|c|c|c|c|}
\hline IL & SYS & DEVICE & P\&ID & ALARM & IL $A C T I O N /(H W$ or SW) & FUNCTION & LOCATION & TESTED & COMMENTS \\
\hline 10 & SNL/SLL & PT3125B & 403 & P>70PSIG & STOP TRANSFER PUMP/S & BP-B INLET P & DB PUMP RM & POTP-007 & 3.38 \\
\hline 11 & SLL & LDE3151 & 404 & LEAK & STOP P 3125A\&B/H & SUMP LD & VS VAULT & POTP-005 & $10.23 / 10.24$ \\
\hline 11 & SLL & LDK3 150 & 403 & LEAK & STOP P $3125 \mathrm{A \& B} / \mathrm{H}$ & SUMP LD & DB PUMP RM & POTP-005 & $8.23 / 8.24$ \\
\hline 12 & SNL/SLL & LDE3151 & 404 & LEAK & STOP XFER PMP SY-02A/H & SUMP LD & VS VAULT & POTP -005 & $10.19-10.22$ \\
\hline 12 & SNL/SLL & LDK3150 & 403 & LEAK & STOP P102SY02A/H & SUMP LD & DB PUMP RM & POTP-005 & $8.19-8.22$ \\
\hline 13 & SNL/SLL & LDE3151 & 404 & LEAK & INPUT TO $2 \mathrm{E} \& 2 \mathrm{~W}$ MPS/H & SUMP LD & VS VAULT & POTP-005 & 10.25 (Note 3) \\
\hline 13 & SNL/SLL & LDK3150 & 403 & LEAK & INPUT TO $2 \mathrm{E} \& 2 \mathrm{~W} \mathrm{MPS} / \mathrm{H}$ & SUMP LD & DB PUMP RM & POTP-005 & 8.25 (Note 3 ) \\
\hline 14 & SLL & $\mathrm{Pr} 3125 \mathrm{C}$ & 403 & $\mathrm{P}>1250 \mathrm{PSIG}$ & STOP P3125A/S & BP-A OUTLET $P$ & DB PUMP RM & ATP-004/POTP007 & $9.10 / / 2.39$ \\
\hline 14 & SLL & PT3125D & 403 & $\mathrm{P}>1250 \mathrm{SPIG}$ & STOP P-3125B/S & BP-B OUTLET P & DB PUMP RM & ATP-004/POTP007 & $10.10 / / 3.39$ \\
\hline 15 & SLL & MOV3125AA & $400 / 2$ & $\neq$ CLOSED & INHIBIT P3125A/S & BP DRAIN VALVE & DB PUMP RM & POTP-007 & 2.40 \\
\hline 15 & SLL & MOV3125AB & $400 / 2$ & $\neq$ CLOSED & INHIBIT P3125A/S & BP DRAIN VALVE & DB PUMP RM & POTP-007 & 2.40 \\
\hline 15 & SLL & MOV $3125 \mathrm{AC}$ & $400 / 2$ & *CLOSED & INHIBIT P3125A/S & BP DRAIN VALVE & DB PUMP RM & POTP-007 & 2.40 \\
\hline 15 & SLL & MOV3125AD & $400 / 2$ & *CLOSED & INIIIBIT P3125A/S & BP DRAIN VALVE & DB PUMP RM & POTP-007 & 2.40 \\
\hline 15 & SLL & MOV3 $125 \mathrm{AE}$ & $400 / 2$ & $\neq$ CLOSED & INHIBIT P3125A/S & BP DRAIN VALVE & DB PUMP RM & POTP-007 & 2.40 \\
\hline 15 & SLL & MOV3125AF & $400 / 2$ & \#CLOSED & INHIBIT P3125A/S & BP DRAIN VALVE & DB PUMP RM & POTP-007 & 2.40 \\
\hline 15 & SLL & MOV3125AG & $400 / 2$ & \#CLOSED & INHIBIT P3125A/S & BP DRAIN VALVE & DB PUMP RM & POTP-007 & 2.40 \\
\hline 15 & SLL & MOV3125AH & $400 / 2$ & \#CLOSED & INHIBIT P3125A/S & BP DRAIN VALVE & DB PUMP RM & POTP-007 & 2.40 \\
\hline 15 & SLL & MOV $3125 \mathrm{AJ}$ & $400 / 2$ & \#CLOSED & INHIBIT P3125A/S & BP DRAIN VALVE & DB PUMP RM & POTP-007 & 2.40 \\
\hline 15 & SLL & MOV3125AK & $400 / 2$ & $\neq$ CLOSED & INHIBIT P3125A/S & BP VENT VALVE & DB PUMP RM & POTP-007 & 2.40 \\
\hline 15 & SLL & MOV3I25BA & $400 / 2$ & $\neq$ CLOSED & INHIBIT P-3125B/S & BP DRAIN VALVE & DB PUMP RM & POTP-007 & 3.40 \\
\hline 15 & SLL & MOV3125BB & $400 / 2$ & $\neq$ CLOSED & INHIBIT P-3125B/S & BP DRAIN VALVE & DB PUMP RM & POTP-007 & 3.40 \\
\hline 15 & SLL & MOV $3125 \mathrm{BC}$ & $400 / 2$ & $\neq$ CLOSED & INHIBIT P-3125B/S & BP DRAIN VALVE & DB PUMP RM & POTP-007 & 3.40 \\
\hline 15 & SLL & MOV3125BD & $400 / 2$ & $\neq$ CLOSED & INHIBIT P-3125B/S & BP DRAIN VALVE & DB PUMP RM & POTP-007 & 3.40 \\
\hline 15 & SLL & MOV3125BE & $400 / 2$ & $¥$ CLOSED & INHIBIT P-3125B/S & BP DRAIN VALVE & DB PUMP RM & POTP-007 & 3.40 \\
\hline 15 & SLL & MOV $3125 \mathrm{BF}$ & $400 / 2$ & $\neq$ CLOSED & INHIBIT P-3125B/S & BP DRAIN VALVE & DB PUMP RM & POTP-007 & 3.40 \\
\hline 15 & SLL & MOV3125BG & $400 / 2$ & *CLOSED & INHIBIT P-3125B/S & BP DRAIN VALVE & DB PUMP RM & POTP-007 & 3.40 \\
\hline
\end{tabular}




\begin{tabular}{|c|c|c|c|c|c|c|c|c|c|}
\hline $\mathrm{IL}$ & SYS & DEVICE & P\&ID & ALARM & IL ACTION/(HW or SW) & FUNCTION & LOCATION & TESTED & COMMENTS \\
\hline 15 & SLL & MOV3125BH & $400 / 2$ & $\nexists$ CLOSED & INHIBIT P-3125B/S & BP DRAIN VALVE & DB PUMP RM & POTP-007 & 3.40 \\
\hline 15 & SLL & MOV3125BJ & $400 / 2$ & $\neq$ CLOSED & INHIBIT P-3125B/S & BP DRAIN VALVE & DB PUMP RM & POTP-007 & 3.40 \\
\hline 15 & SLL & MOV3125BK & $400 / 2$ & ${ }^{*}$ CLOSED & INHIBIT P-3125B/S & BP VENT VALVE & DB PUMP RM & POTP-007 & 3.40 \\
\hline 15 & SLL & SOV3163 & 403 & FCLOSED & INHIBIT P3125A/B/S & PROCESS VV & DB PUMP RM & POTP-007 & $2.40,3.40$ \\
\hline 16 & SNL & PSH3113 & 402 & $\mathrm{P}>18 \mathrm{PSIG}$ & 2W MPS SHUTDOWN/H & SYS. PRESS & 241SYA VP & POTP-005 & $12.34-12.37$ (Note I) \\
\hline 16 & SNL & PSH3113A & 402 & $P>18 P S I G$ & 2W MPS SHUTDOWN/H & SYS. PRESS & 24ISYA VP & NEW & NEW (Note 4) \\
\hline 17 & SNL & ZSH31:3 & 402 & $\neq \mathrm{CLOSED}$ & 2W MPS SHUTDOWN/H & VALVE POSITION & 241SYA VP & POTP-005 & $12.39-12.43$ (Note 1) \\
\hline 18 & SNL/SLL & LIT302C-1 & 409 & LEVEL $<5^{\prime}$ & STOP P3100A & FLUSH TK LEVEL. & FLUSH TK & POTP-001 & $4.37-4.39$ \\
\hline 19 & SNL/SLL & FSL302C-4A & $400 / 1$ & NO FLOW & SHUTDOWN HTR $2 / \mathrm{H}$ & FLUSH FLOW & FLUSH SKID & POTP-001 & $5.4-5.7$ \\
\hline 19 & SNL/SLL & FSL302C-4B & $400 / 1$ & NO FLOW & SHUTDOWN HYR 1/H & FLUSH FLOW & FLUSH SKID & POTP-001 & $5.4-5.7$ \\
\hline 19 & SNL/SLL & $\operatorname{TIC} 302 \mathrm{C}-4 \mathrm{C}$ & $400 / 1$ & $\mathrm{~T}>180^{\circ} \mathrm{F}$ & SHUTDOWN HTR $2 / \mathrm{H}$ & PROCESS TEMP HI & FLUSH SKID & POTP-001 & $5.72-5.80$ \\
\hline 19 & SNL/SLL & TIC $302 C-4 D$ & $400 / 1$ & $\mathrm{~T}>180^{\circ} \mathrm{F}$ & SHUTDOWN HTR $1 /$ H & PROCESS TEMP HI & FLUSH SKID & POTP-001 & $5.26-5.34$ \\
\hline 19 & SNL/SLL & TIC302C-4E & $400 / 1$ & $\mathrm{~T}>375^{\circ} \mathrm{F}$ & SHUTDOWN HTR $2 / \mathrm{H}$ & SHEATH TEMP HI & FLUSH SKID & POTP-00I & $5.87-5.94$ \\
\hline 19 & SNL/SLL & TIC302C-4F & $400 / 1$ & $\mathrm{~T}>375^{\circ} \mathrm{F}$ & SHUTDOWN HTR $1 / \mathrm{H}$ & SHEATH TEMP HI & FLUSH SKID & POTP-00I & $5.41-5.48$ \\
\hline 20 & SNL & PT3167 & 404 & $P>10 P S I G$ & SHUT DOWN XFER PUMP/S & SUPER PRESS & VS PUMP RM & POTP-005 & $7.0-7.12$ \\
\hline 20 & SNL & PT3173 & 403 & $\mathrm{P}>10 \mathrm{PSIG}$ & STOP P102SY02A/S & SUMP TO SUPER & DB PUMP RM & POTP-005 & $6.0-6.12$ \\
\hline 20 & SNL & PT3185 & 404 & $P>10$ PSIG & SHUT DOWN XFER PUMP/S & SUPER PRESS & VS PUMP RM & POTP-007 & $2.44-2.56$ \\
\hline 21 & SNL & PT312SE & 403 & $\mathrm{P}>0 \mathrm{PSIG}$ & INHIBIT SUMP VALVES & SUMP DISCHARGE & DB PUMP RM & POTP-005 & $5.8-5.14$ \\
\hline 21 & SNL & РТ3126E & 404 & $\mathrm{P}>0 \mathrm{PSIG}$ & INHIBIT SUMP VALVES & SUMP DISCHARGE & VS PUMP RM & POTP-005 & $4.9-4.14$ \\
\hline
\end{tabular}




\section{W-058 Interlock Test Listing}

Notes:

Jumpers not installed at the time of the test. Testing was performed, using appropriate signals, from the connection point at the pit interface.

2 LSL3102 (Level in Tank SY-102) does not show in the current design as a control element. (Wiring was removed per project ECN W-058-339, pages 4 and 9.) However, the functional control of this device was tested as part of ATP-003, section 9.1 in the event that it is reinstated..

3 In accordance with design requirements, W-058 leak detection is not connected to the 200E Tank Farm Master Pump Shutdown (MPS) scheme. Interposing relays are provided at the 244A lift station for future connection, if desired. These relays were tested for proper action. The project is connected to the 200W.MPS and this connection was also tested.

4 Device PT3113A is redundant to PT3113. This device was not installed prior to the completion of testing for POTP-005. 


\section{ATTACHMENT - 7}

\section{CAUSTIC TO RAW WATER FLOW MEASUREMENT TOLERANCE}

Calculation note W-058-P-050 (Reference number 3), pH adjustment of water using sodium hydroxide pump injection rate, on page 4 , specifies that at a raw water flow rate of $170 \mathrm{gpm}$ the required caustic flow is $12.4 \mathrm{gph}$ to raise the $\mathrm{pH}$ to 11 . This criteria however doesn't include any tolerance resulting rom the raw water flow measurement accuracy (FE/FT-302C-2) nor the caustic flow measurement accuracy (calibrated column visual reading/timing).

Hence acceptance criteria 6.4 has been updated to reflect this tolerance as follows:

Criteria: $12.4 \mathrm{gph}$ caustic for $170 \mathrm{gpm}$ raw water (i.e.: $12.47 \mathrm{gph}$ for $171 \mathrm{gpm}$ )

Measurements: 12.21 gph caustic for $171 \mathrm{gpm}$ raw water

Deviation: $\underline{12.47-12.21} \times 100=2 \%$

12.47

\begin{tabular}{|l|l|l|l|l|l|}
\hline FLOW & DEVICE & RANGE & $\begin{array}{l}\text { FULL SCALE } \\
\text { ACCURACY }\end{array}$ & $\begin{array}{l}\text { MEASURE- } \\
\text { MENT }\end{array}$ & $\begin{array}{l}\text { MEASURE- } \\
\text { MENT } \\
\text { ACCURACY }\end{array}$ \\
\hline Raw Water & FE/FT-302C-2 & $0-350 \mathrm{gpm}$ & $\pm 3 \%=10.5 \mathrm{gpm}$ & $171 \mathrm{gpm}$ & $\mathrm{R}= \pm 6 \%$ \\
\hline Caustic & $\begin{array}{l}\text { Calibrated } \\
\text { column visual } \\
\text { reading/timing }\end{array}$ & $500 \mathrm{ml}$ & $\begin{array}{l} \pm 1 / 2 \text { increment } \\
= \pm 5 \mathrm{ml}\end{array}$ & $12.21 \mathrm{gpm}$ & $\mathrm{C}= \pm 5 \%$ \\
\hline
\end{tabular}

The overall tolerance on the caustic flow measurement is calculated as follows:

$T= \pm \sqrt{R^{2}+C^{2}}= \pm \sqrt{36+25}= \pm 7.8 \%$

Conservatively a tolerance of $\pm 5 \%$ has been retained for the acceptance criteria.

Hence the measured caustic to raw water ratio $(2 \%)$ is within the acceptable tolerance $( \pm 5 \%)$. 
DISTRIBUTION SHEET

\begin{tabular}{|c|c|c|c|c|c|c|}
\hline \multirow{2}{*}{$\begin{array}{l}\text { To } \\
\text { Distribution }\end{array}$} & \multirow{2}{*}{\multicolumn{4}{|c|}{$\begin{array}{l}\text { From } \\
\text { E.A. Pacquet - W-058 Testing }\end{array}$}} & \multicolumn{2}{|c|}{ Page 1 of 1} \\
\hline & & & & & \multicolumn{2}{|c|}{ Date } \\
\hline \multirow{2}{*}{\multicolumn{5}{|c|}{$\begin{array}{l}\text { Project Title/Work Order } \\
\text { Replacement Cross-Site Tranfer System }\end{array}$}} & \multirow{2}{*}{\multicolumn{2}{|c|}{$\begin{array}{ll}\text { EDT No. } & 623663 \\
\text { ECN No. } & \text { N/A }\end{array}$}} \\
\hline & & & & & & \\
\hline \multicolumn{2}{|l|}{ Name } & MSIN & $\begin{array}{l}\text { Text } \\
\text { With All } \\
\text { Attach. }\end{array}$ & Text Only & $\begin{array}{l}\text { Attach./ } \\
\text { Appendix } \\
\text { Only }\end{array}$ & $\begin{array}{c}\text { EOT/ECN } \\
\text { Only }\end{array}$ \\
\hline $\begin{array}{l}\text { R.J. Brown, LMHC } \\
\text { W.G. Brown, LMHC } \\
\text { J.E. Dunks, FDNW } \\
\text { L.R. Hal1, FDNW } \\
\text { B.J. Harp, DOE-RL } \\
\text { D.A. Greenaway, LMHC } \\
\text { J.L. Henderson, FDNW } \\
\text { O.M. Jaka, LMHC } \\
\text { R.L. Legg, LMHC } \\
\text { D.R. Nunamaker, LMHC } \\
\text { E.A. Pacquet, NHC } \\
\text { G.L. Parsons, NHC } \\
\text { C.R. Rejchmuth, LMHC } \\
\text { M.J. Sutey, LMHC } \\
\text { C. van Katwijk, NHC } \\
\text { M.D. Gerken, NHC } \\
\text { D.0. Dobson, LMHC } \\
\text { M.J. Bailey, LMHC } \\
\text { Project Files }\end{array}$ & & $\begin{array}{l}\text { T4-08 } \\
\text { T4-07 } \\
\text { R3-47 } \\
\text { R3-47 } \\
\text { S7-54 } \\
\text { T4-09 } \\
\text { G3-14 } \\
\text { S5-12 } \\
\text { R2-50 } \\
\text { T4-07 } \\
\text { R3-47* } \\
\text { R3-47* } \\
\text { T4-07* } \\
\text { T4-08 } \\
\text { R3-47 } \\
\text { R3-47* } \\
\text { R2-50 } \\
\text { T4-07 } \\
\text { R1-29 }\end{array}$ & $\begin{array}{l}x \\
x \\
x \\
x \\
x \\
x \\
x \\
x \\
x \\
x \\
x \\
x \\
x \\
x \\
x \\
x \\
x \\
x \\
x \\
x \\
\end{array}$ & & . & . \\
\hline
\end{tabular}

* Advance Copy 